\title{
WestVirginiaUniversity
}

THE RESEARCH REPOSITORY @ WVU

Graduate Theses, Dissertations, and Problem Reports

2005

\section{Three essays on international trade and factor flows}

Ryo Takashima

West Virginia University

Follow this and additional works at: https://researchrepository.wvu.edu/etd

\section{Recommended Citation}

Takashima, Ryo, "Three essays on international trade and factor flows" (2005). Graduate Theses,

Dissertations, and Problem Reports. 2268.

https://researchrepository.wvu.edu/etd/2268

This Dissertation is protected by copyright and/or related rights. It has been brought to you by the The Research Repository @ WVU with permission from the rights-holder(s). You are free to use this Dissertation in any way that is permitted by the copyright and related rights legislation that applies to your use. For other uses you must obtain permission from the rights-holder(s) directly, unless additional rights are indicated by a Creative Commons license in the record and/ or on the work itself. This Dissertation has been accepted for inclusion in WVU Graduate Theses, Dissertations, and Problem Reports collection by an authorized administrator of The Research Repository @ WVU.

For more information, please contact researchrepository@mail.wvu.edu. 
Three Essays on International Trade and Factor Flows

Ryo Takashima

\author{
Dissertation submitted to \\ the College of Business and Economics \\ at West Virginia University \\ in partial fulfillment of the requirements \\ for the degree of \\ Doctor of Philosophy \\ in \\ Economics
}

Subhayu Bandyopadhyay, Ph.D., Chair

Ronald J. Balvers, Ph.D.

Stratford M. Douglas, Ph.D.

Santiago M. Pinto, Ph.D.

Mehmet S. Tosun, Ph.D.

Division of Economics and Finance

Morgantown, West Virginia

2005

Key words: Trade policy, Factor Flows, Trade impact

(c) Copyright by Ryo Takashima, 2005 


\section{Abstract \\ Three Essays on International Trade and Factor Flows}

\section{Ryo Takashima}

The dissertation aims to help us understand the economic mechanism of and the impacts of international trade and factor flows. It comprises three essays, each of which focuses on a separate aspect of trade and factor flows.

The first essay illuminates the issue of trade policy and illegal immigration in a rigorous theoretical analysis. We emphasize the presence of the interrelationship between trade policy and illegal immigration by employing the so called Meade model. First, we present an analysis of the relationship between trade policy and illegal immigration. Second, we analyze the welfare effects of complete movement to free trade in the presence of illegal immigration. Third, we illustrate the conditions under which bilateral trade negotiations are compatible with multilateral trade negotiations. Finally, we extend the analysis to a large open economy case. Terms of trade effects add some complexity to the effects of trade liberalization on illegal immigration and economic welfare.

The second essay focuses on the effect of international trade and factor flows on domestic taxation. We examine how the effective tax rates of labor, capital and consumption (for OECD members) are related to economic integration. The empirical analysis extends the existing literature by incorporating factor flows into the equation. We find that labor flows have a negative association with the effective tax rates of capital and consumption. The trade volume is found to have a relatively weak link with taxation.

The third essay scrutinizes the effect of trade policy on domestic wage rates by looking into different regions of the US economy. The main purpose is to conduct an empirical analysis of the effects of trade policy on regional wage differences. We find some evidence that various tariffs and non-tariff barriers have had regional impacts on the skill premium in US wages. The overall findings indicate that regional impacts of trade policy may differ. This suggests a need for more careful assessment of welfare effects at the regional level. 


\section{Acknowledgements}

I would like to thank my advisor, Prof. Subhayu Bandyopadhyay, for his invaluable guidance and support throughout the course of my graduate study. I also thank the committee members, Prof. Ron Balvers, Prof. Strat Douglas, Prof. Santiago Pinto, and Prof. Mehmet Tosun for their helpful comments and suggestions which have greatly improved this dissertation. Special thanks go to Prof. Arabinda Basistha for his suggestions in general and for his help with econometrics, in particular. I would also like to thank Tomi Ovaska, Rachel Faerber-Ovaska, Nathan Ashby and Matt McPherson for their valuable comments and editorial assistance. 


\section{Table of Contents}

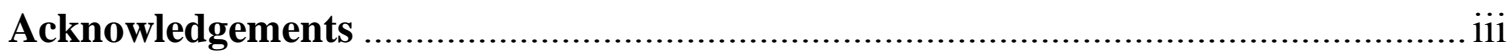

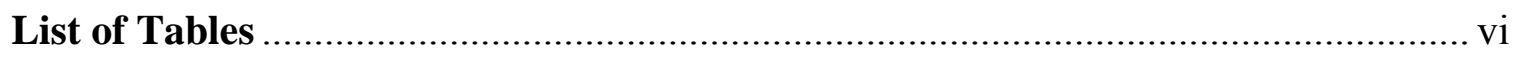

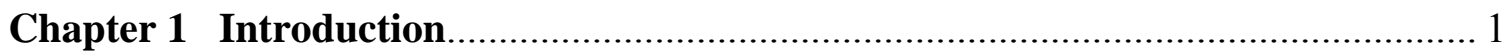

Chapter 2 Trade Policy and Illegal Immigration............................................... 9

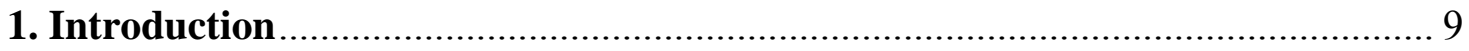

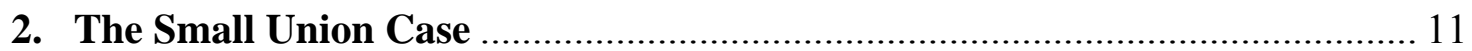

2.1. The effect of trade liberalization on the level of illegal immigration .............. 13

2.2. The Pre-Agreement Nash Tariff Equilibrium ........................................ 15

2.3. The effect of a Free Trade Agreement on national welfare ........................... 18

2.4. Is multilateral trade liberalization compatible with bilateral trade

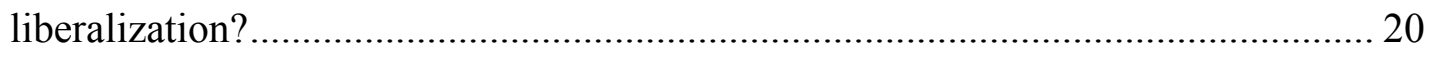

3. Large Open Economy .............................................................................. 22

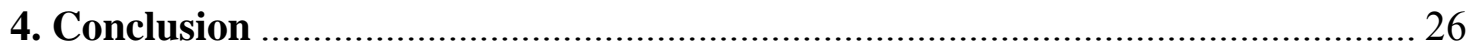

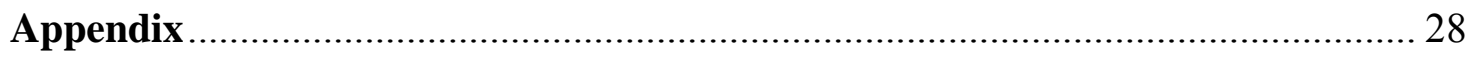

Chapter 3 The impact of Trade and Factor Flows on Domestic Taxation ............. 33

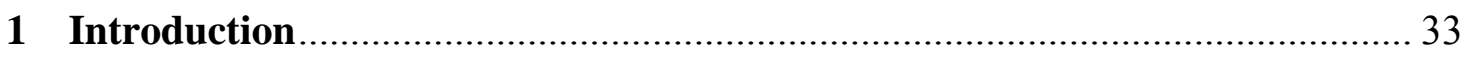

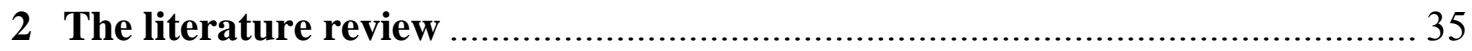

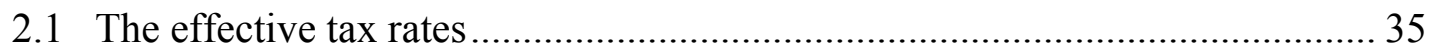

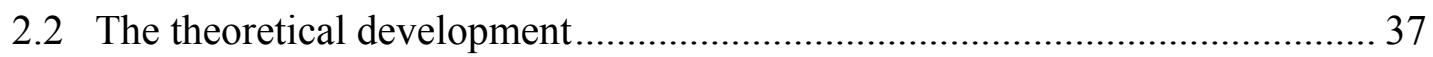

2.3 Review of some relevant empirical works........................................... 41

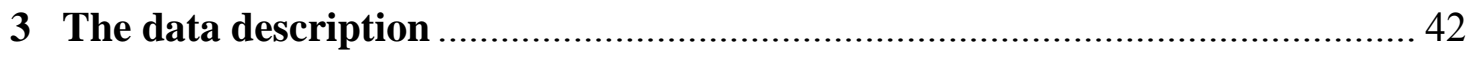

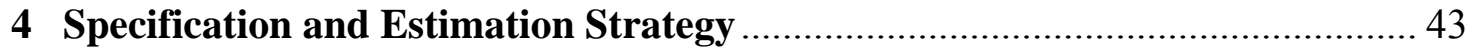




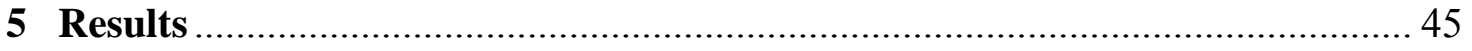

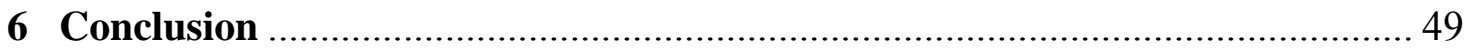

Chapter 4 The Search of Heterogeneous Impacts of Trade Barriers across Regions

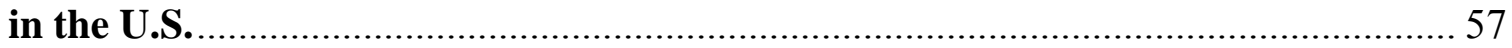

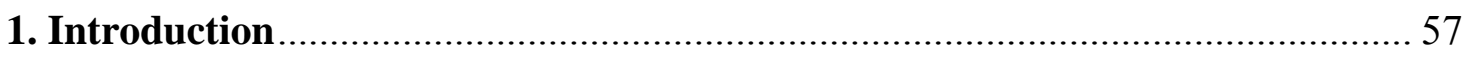

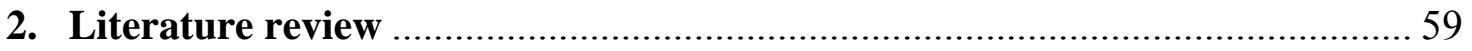

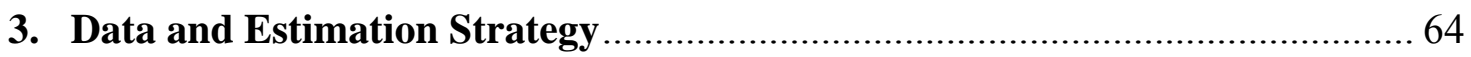

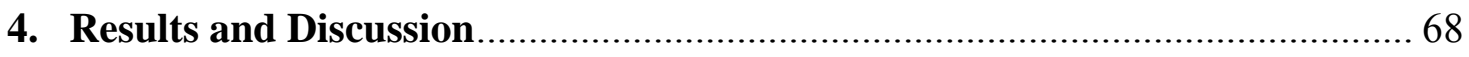

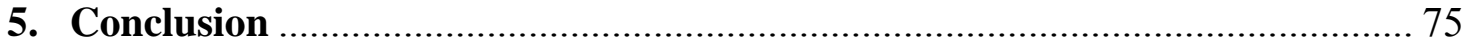

Chapter 5 Conclusion and the Direction of Future Research.............................. 90

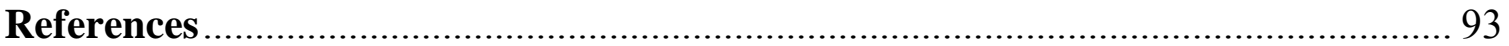




\section{List of Tables}

Table 1 Description of the variables.......................................... 51

Table 2 Summary Statistics of tax rates: mean and standard deviation over the

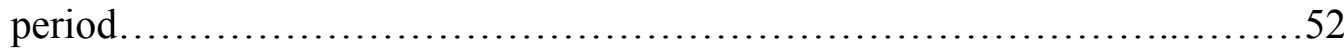

Table 3 Fixed Effects Estimations............................................53

Table 4 Fixed Effects with lagged tax rates......................................54

Table 5 Instrumental Variable Estimations.......................................... 55

Table 6 Arellano-Bond dynamic panel data estimates Estimations...................56

Table 1 The list of US regions............................................... 80

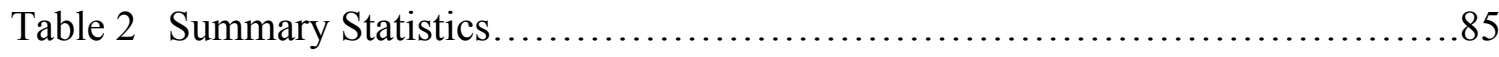

Table 3 Industry Specific Effects of Tariff and NTB $\ldots \ldots \ldots \ldots \ldots \ldots \ldots \ldots \ldots \ldots \ldots$ 


\section{CHAPTER 1}

\section{Introduction}

The world is seeing unprecedented levels of international trade and globalization. The trade volume of the world four decades ago was just above 1.6 trillion dollars (1995 US\$), or 25 percent of the world GDP. Twenty-three countries in OECD shared about 92 percent of the world trade volume, or equivalently 23 percent of the world GDP. Since then, the figure has grown exponentially. By the end of twentieth century, the world traded goods and services worth 16 trillion dollars (1995 US\$). This is a tenfold increase in four decades. Currently, the world economy relies on international trade for about 46 percent of its GDP. OECD's trade volume has gone up to 11 trillion dollars. This is 89 percent of the world trade volume, and equivalent to 40 percent of the world GDP. NonOECD countries also increased their trade volume from 524 billion dollars to more than 5 trillion dollars.

[figure 1] 


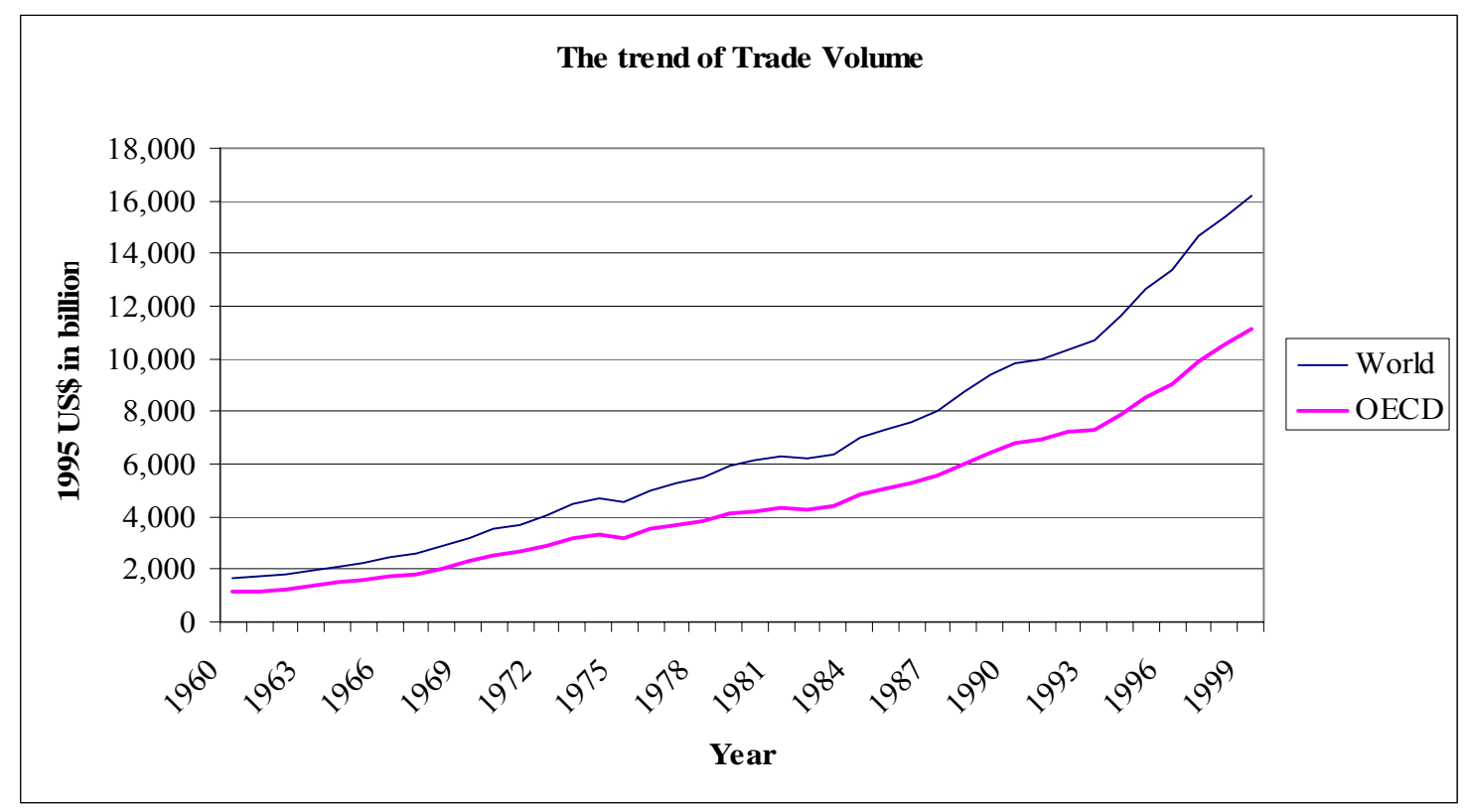

The process of economic integration is not limited to an increased flow of merchandise. Production inputs are also crossing borders around the world. Gross Foreign Direct Investment (FDI) for OECD countries was merely 1 percent of GDP in 1970. Now, the figure is reaching about 10 percent of GDP. In 1970, gross private capital flows (which include both direct and indirect investment) were below 10 percent of GDP in OECD with the solitary exception of the Netherlands. In 2000, the average gross private capital flows amounted to around 59 percent. Countries such as Belgium, the Netherlands, Switzerland, and the United Kingdom have values of capital crossing their borders to exceed their corresponding GDPs. It is a puzzling fact for economists that so much capital heads to the regions where capital is already abundant (as the Center for Global Development pointed out $)^{1}$. However, undoubtedly, in these countries, foreign capital is an indispensable source of economic growth.

\footnotetext{
${ }^{1}$ Refer "Facts and Figures" at the Center for Global Development web site: http://www.cgdev.org/
} 
[figure 2]

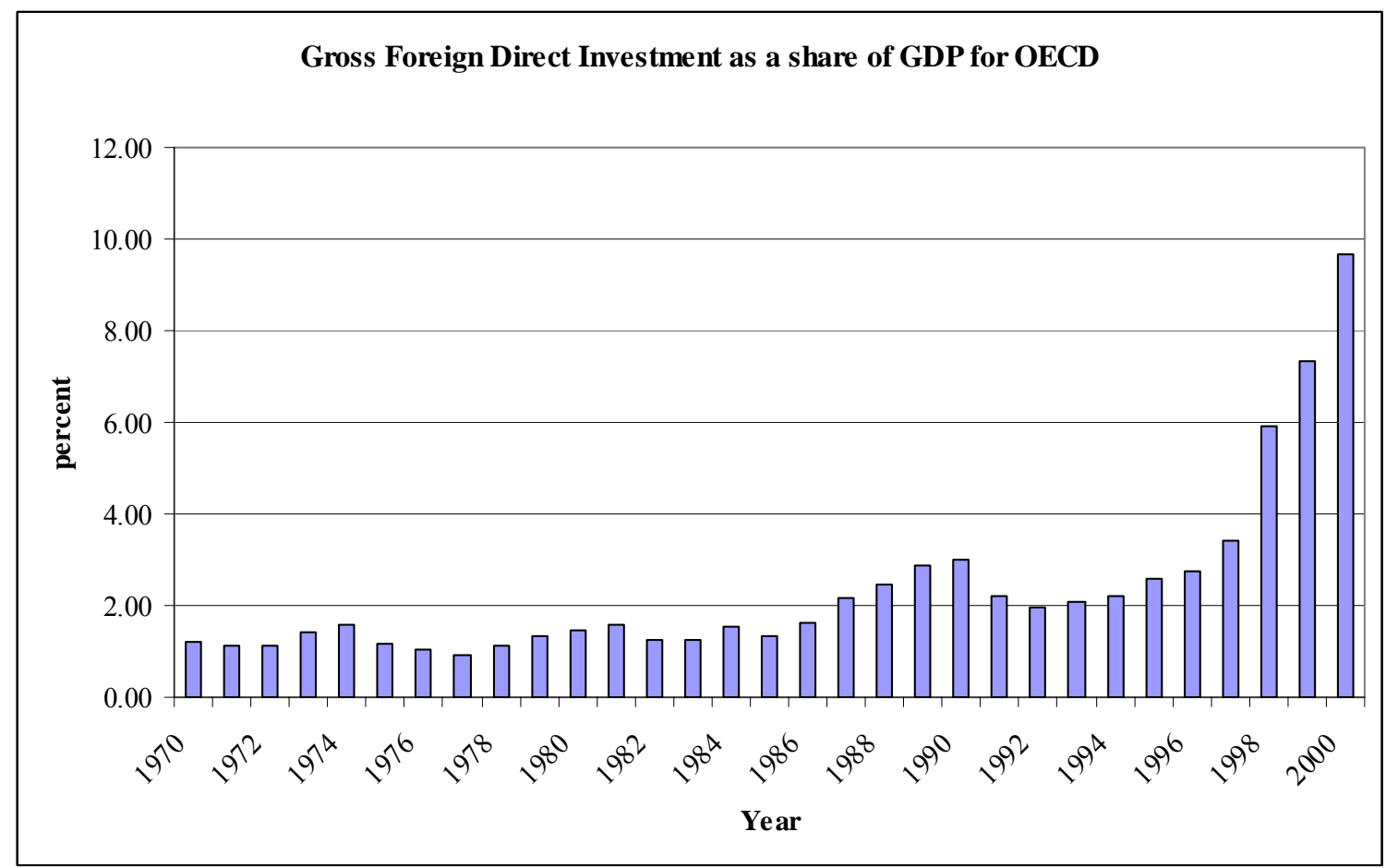

The flows of merchandise and capital have surged in the past decades and this fact stood out among many economic changes we have experienced. The only exception could be the technological improvements. Compared to the movements of merchandise and capital, labor faces a larger barrier to mobility. In almost every country, until the emergence of the European Union, the mobility of workers across borders was very limited. Nevertheless, the share of foreign labor in the total labor force has been on an upward trend except in Australia and in the United Kingdom where the share has been stable for the past decade. Yet, as the population grew, the actual number of foreign labor inflows has been rising even in these two countries.

While we mention the legal mobility of labor, one can imagine that there is a great incentive for illegal migration, as well. Because of the illegal nature, there is no accurate 
official figure on how many illegal laborers have crossed borders or how many have attempted. However, the statistics of border apprehensions are available for some nations and provides some insights into the nature and extent of the problem. In 1961, the number of aliens apprehended at the border of the United States was near 90,000. The number climbed to 1.6 million in 1996 according to the Immigration and Naturalization Service Statistics. It is clear that there is a growing pressure of labor inflows, either legal or illegal.

[figure 3]

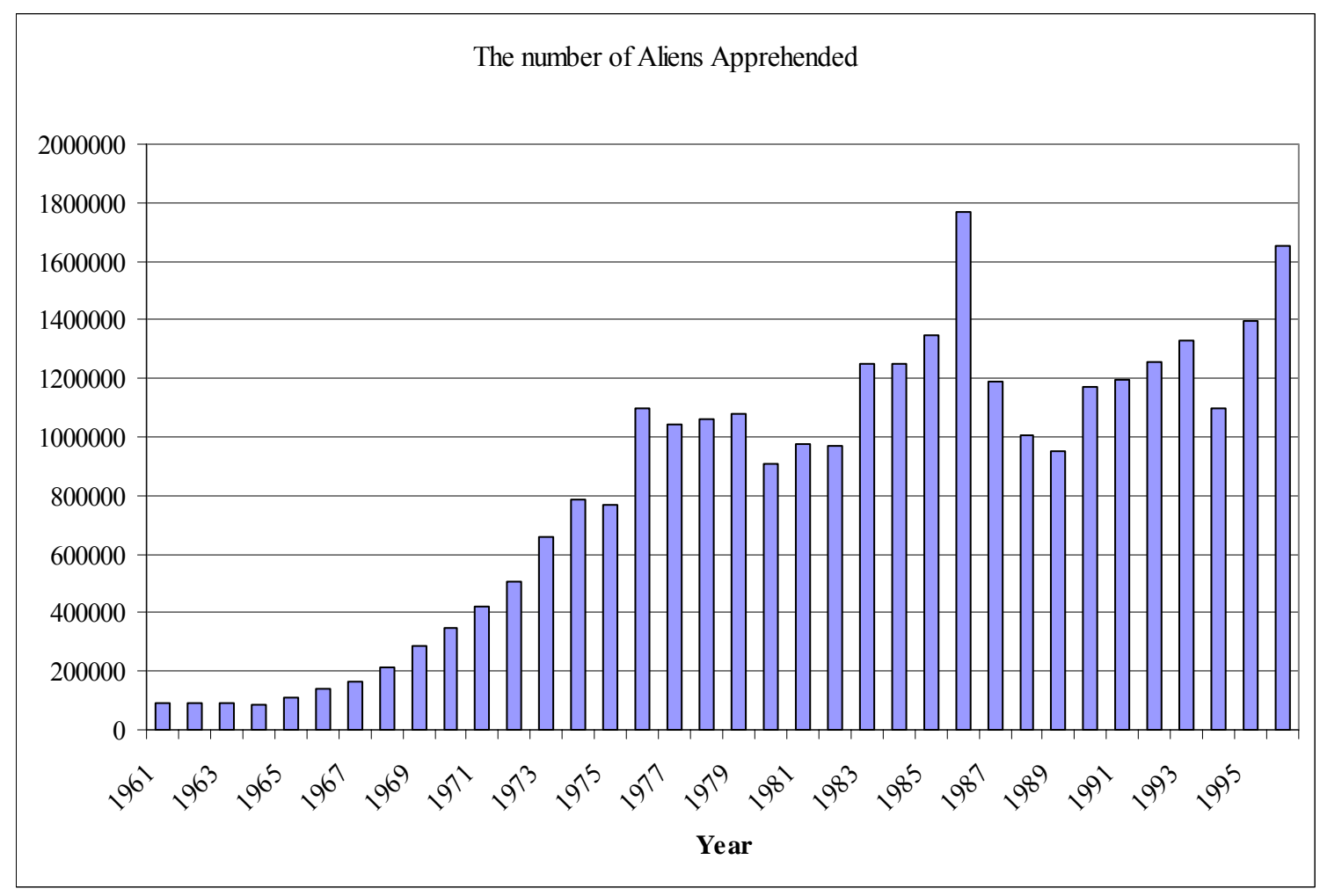

The increase in the flows of merchandise, capital, and labor is a part of the process of economic integration. The wave of economic integration reaches almost every society and the effects are felt by people administering customs restrictions at ports, shoppers at local retail stores, and job seekers at local labor markets. This dissertation 
focuses on three distinct phenomena that are related to international trade and factor flows that are associated with such economic integration.

First, we look into the relation between trade policy and illegal immigration. We have already mentioned some facts regarding an increasing number of border apprehensions in the United States. Naturally, the number of those who attempted to cross the border illegally should far exceed the number of apprehensions. According to the United States General Accounting Office, 1,013 migrants died trying to cross the Southwest border illegally between October 1997 and June 2001 of which 60 percent died from either heat exposure or drowning. Other deaths are attributed to exposure to cold, motor vehicle accidents, train accidents, confined space, etc. Some 15 percent of deaths are from unknown causes. Because of the financial cost of enforcement and the humanitarian costs associated with illegal immigration, it is important to understand the relation between enforcement policy, trade policy and illegal immigration. We use the Meade model that includes three countries and three goods, of which two share a border. When policy is unilaterally determined, two countries sharing a border set their optimal tariffs after recognizing how they impact border and internal enforcement. At a first glance, it may seem that trade policy and enforcement policy are unrelated. However, we argue that is not true. Tariffs alter domestic prices and wages and influence the incentives of migrants. We analyze how these incentives are altered due to trade liberalization thereby affecting illegal immigration. We analyze the condition under which a complete movement toward free trade improves the economic welfare of the countries involved. We also discuss a situation where multilateral and bilateral trade liberalization are compatible in the presence of illegal immigration. Finally, the analysis 
is extended to the large union case where the complex relations between tariffs, terms of trade, and illegal immigration are present.

Second, we move our focus to domestic taxation in relation to economic integration. We particularly examine OECD countries where there has been significant extent of economic integration. These countries though their goods markets and factor markets are more open to the world than ever but differ in the extent to which they rely on international trade. In the year 2000, the trade volume as a percentage of GDP exceeded 100 percent for the countries such as Belgium, Ireland, Luxembourg, and the Netherlands. Japan and the United States had corresponding figure of 18 and 24 percentage, respectively. The reliance on foreign labor in each country is also significantly different. For instance, Luxembourg's share of foreign labor was above 57 percent. Australia follows with 24 percent. Austria and Switzerland had 10 percent and 18 percent, respectively. The figure for Japan was less than 1 percent. Finland and Spain barely exceeded 1 percent. Thus, the integration of labor markets significantly varies across OECD members. The same is true for FDI. The net inflow of FDI as a share of GDP exceeded 20 percent for Denmark and Ireland in 2000. Compared to these countries, Greece and Japan received FDI of about 0.9 and 0.1 percent, respectively.

Although all OECD countries have become much more open, some experienced rapid integration with high growth of trade of merchandise and factor flows, while others have opted for a slower speed. Has this difference contributed to the difference in domestic taxation among OECD countries? The effective tax rates on earnings from capital income in Sweden and the United Kingdom exceed 50 percent while the 
corresponding rate in Spain is 15 percent. When one compares the taxation on earnings from labor income, the Netherlands impose the highest - nearly 50 percent of the effective labor tax rate, while the lowest was in Australia with 16 percent. For the taxes on consumption, Denmark and Norway have the effective consumption tax rates of near 35 percent, while Japan, Switzerland, and the United States are well below 10 percent. Can these differences in domestic taxation be explained by the differences in economic integration? We tackle this question empirically and find that the impact of economic integration on taxes on capital and labor is weak. We also observe that an increasing intensity of economic integration in the form of more trade and factor flows is associated with a lower effective consumption tax rate. Labor inflow is found to be particularly significant in this link. The consumption tax and possibly capital tax are negatively associated with labor inflow. These findings inform us about how the current trend of globalization can impact each country and its policy making. Developing countries tend to struggle to raise government revenues necessary to provide public services and to implement redistributive policy. This study may be applied to point out another challenge for these nations as they deal with globalization.

Third, we scrutinize whether increasing integration of a nation with the global economy has asymmetric effects on different regions within it. Traditional trade theory assumes regions are homogeneous within a country, and treats a country as a point without space. The idea is that factors are fully mobile within a country. Therefore, when different wage rates are observed among regions, laborers move across regions immediately. This assures that wage rates are equalized among the regions. However, a recent study found that wage equality is often violated in several countries. Bernard, 
Jensen, and Schott (2001) examine whether relative wage rates are equalized in the United States and found evidence against it. Bernard, Redding, Schott, and Simpson (2002) analyze the United Kingdom, and find evidence against wage equalization. Bernard, Robertson, and Schott (2004) study the case of Mexico, and again they find that wage rates are not equalized. These studies provide reasons to doubt the assumption that factors are fully mobile within a country. They furthermore postulate that factor abundance may be sufficiently different across regions and that there may be distinct groups of regions with different comparative advantages in production. If this is the case, changes in trade policy, as a part of economic integration, will have differential regional impacts within a country. As tariff rates and Non-Tariff Barriers are altered, the wage rate in one region can change totally in the opposite direction from another region. We pose this question in the case of the United States and examine it empirically. We utilize the recent data on Non-Tariff Barriers (NTB) in addition to the data on tariff rates in the United States. The information on NTBs is often ignored in the empirical trade literature. However, its importance as trade barriers has been increasing in the past and we believe it is crucial to include. We find that tariffs and NTBs had distinct regional impacts on US wages. Interestingly, NTBs exhibit much greater degree of asymmetric regional effects compared to tariffs. Our findings underline the importance of assessing trade policies not only in terms of their impact on national welfare but also from the perspective of distribution of their effects between regions.

To summarize, this thesis focuses on the following issues: (i). trade policy in the presence of illegal immigration; (ii). impact of integration and openness on domestic taxation; and, (iii). the asymmetric regional impacts of trade policy. 


\section{Chapter 2}

\section{Trade Policy and Illegal Immigration}

\section{Introduction}

Regional trading agreements have become very popular in recent times. Some well known trading blocs are NAFTA, EU, SAARC, and MERCOSUR. However, there are several others which are less prominent. While these agreements strive to eliminate trade barriers within blocs, they typically do not achieve complete free trade (see Baldwin and Venables, 1995). Each member tries to pursue their own interests such as the amount of tariff reduction that they are willing to concede in return for better access to their partners' markets. Also, the issues on the negotiation table are not limited to trade policy alone, but cover a variety of related problems. Illegal immigration is one of the important related issues, especially for PTAs that involve bordering nations.

Illegal immigration has been a serious problem in NAFTA, especially along the US-Mexico border. Recent estimates (see Orrenius 2001) suggest that there are about 3 million undocumented Mexican immigrants in the US in 1997. About 202,000 Mexicans immigrated per year between 1987 and 1996. Tariffs change domestic prices, and cause adjustment between different sectors and indirectly affect the labor market. The resulting change in labor market conditions influence immigration flows. On the other hand, immigration flows due to changes in the source nation or due to policy, directly affect the labor market. Clearly, these two issues, tariff and immigration, are interrelated. Thus trade negotiations have to and do consider these issues simultaneously. ${ }^{2}$

\footnotetext{
${ }^{2}$ NAFTA negotiations/documents discuss both tariff liberalization and ways to control illegal labor flows. Former Attorney General Reno called the Free Trade Agreement with Mexico “...our best hope for reducing
} 
The literature on regional trade agreements has explored a variety of issues (see for example, Ethier and Horn, 1984, Baldwin and Venables, 1995, Bhagwati, Krishna, and Panagariya, 1999). Ethier and Horn (1984) have shown that (i) marginal reduction of tariff improves joint-welfare of trade bloc when starting from non-discriminatory tariff, and (ii) marginal increase in internal tariff improves joint-welfare of trade bloc when starting from free intra-trade bloc in a tariff-ridden world. These imply the presence of the optimal positive internal tariff. Panagariya (1999) derives the second best optimal tariff within the context of the Meade Model. In addition to the analysis of marginal changes in tariffs, the literature has also explored the welfare implications of complete tariff elimination. Panagariya and Krishna (2002) consider circumstances under which an FTA must improve the joint welfare of the bloc.

While the existing literature has deepened our understanding of the nature of optimal trade taxes and of the welfare implications of regional integration, it has not adequately addressed the issue of illegal immigration. The agenda of this paper is to contribute towards improving our understanding of this issue by complementing the existing literature in four ways. First, we consider how a mutual tariff reduction by bloc members alters the level of illegal immigration. Second, we describe the nature of the non-cooperative equilibrium within the bloc. Third, we analyze the welfare effect of complete intra-bloc tariff elimination (as in an FTA). Finally, the analysis is extended to consider terms of trade effects of tariff changes (within the context of a trade bloc involving large nations) and how these impact the illegal immigration problem.

illegal immigration over the long haul.” http://www.clintonfoundation.org/legacy/101293-fact-sheet-onnafta-notes.htm 
The rest of the paper is organized in the following way. Section 2 presents the basic model and analyzes the small-union case. Section 3 extends the analysis to consider terms of trade effects. Section 4 concludes.

\section{The Small Union Case}

We use the small-union Meade model used in Panagariya (1999) and Bandyopadhyay (2003). There are three nations, A, B, and C. Nations A and B form a Preferential Trade Agreement (PTA). There are three goods; good-1, 2, and 3. Nations A and B both produce goods 1 and 2. Nation A exports good-1 and imports goods 2 and 3. Nation B exports good-2 and imports goods 1 and 3. Nation C produces and exports good-3 while it imports goods 1 and 2 . We assume A and B impose import tariffs while C pursues free trade. Trade liberalization within the bloc takes place as A reduces or eliminates import tariff on good-2 and B does the same for its import tariff on good-1. These tariffs may be denoted as internal tariffs (internal to the bloc) while the tariffs by A and B on good-3 are their respective external tariffs. We abstract from strategic interactions in trade policy between the Bloc and the rest of the world, and focus on intrabloc strategic tariffs, tariff liberalization and how it affects the illegal immigration problem. ${ }^{3}$ Nation A is the host country for illegal immigration, while B is the source

\footnotetext{
${ }^{3}$ Bandyopadhyay (2003) does address tariffs and illegal immigration. However, unlike this paper he ignores the interdependence in trade policy between the bloc members. The role of the latter and how it affects illegal immigration and national welfare is the central focus of this paper. It should be noted that interdependence in trade policy is discussed (between a trading bloc and the rest of the world) in Bond, Syropoulos, and Winters (2001) and Bond, Riezman, and Syropoulos (2004). Bond, Syropoulos, and Winters (2001) among others shed light on the mutual negotiation process. They examine how formation of customs union with a certain country affects its trade agreements with other countries (multilateral agreements). Their paper derives external tariff response functions of the customs union and the rest of world, and thus provides the conditions under which both a customs union and multilateral trade agreements are sustainable. Our paper differs from the Bond et al. papers in two respects. First, we focus
} 
country. Illegal immigrants send earnings back to B, thus, A does not retain immigrant's factor rewards (for example, Orrenius (2001) states that: "The out-migration of Mexican citizens brings in $\$ 4$ billion to $\$ 7$ billion in remittances each year.”). Since prices (without tariffs) are given exogenously to the small countries within the bloc, we normalize them to be unity. ${ }^{4}$ Illegal immigrants earn the wage $W_{I}$ and the level of illegal immigration itself is $I$. Their total earning is $W_{I} I$, which is repatriated to $\mathrm{B}$. Thus, this amount must be subtracted from A's revenue and added to B's revenue. The legal wage rate of nations $\mathrm{A}$ and $\mathrm{B}$ are denoted as $W^{A}$ and $W^{B}$, respectively. The legal wage $W^{A}$ is assumed to exceed $W^{B}$ (this may be due to technology differences, tariffs, or other reasons). This creates incentives for immigrants to illegally cross the border. Nation A uses internal enforcement and border enforcement to control illegal immigration. The enforcement costs are $e_{i}$ (internal) and $e_{b}$ (border), respectively. The tariff on good i by nation $\mathrm{j}$ is $t_{i}^{j}$ where $\mathrm{i}=\operatorname{good} 1,2$, and 3 , and $\mathrm{j}=$ nations $\mathrm{A}$ and $\mathrm{B}$. The standard expenditure-revenue equations for the three nations are described below. The partial derivatives of expenditure and revenue functions are denoted by subscripts. For instance, $E_{2}^{A}$ is the partial derivative of A's expenditure function with respect to price of good-2.

(1) $E^{A}\left(1,1+t_{2}^{A}, 1+t_{3}^{A}, u^{A}\right)=R^{A}\left(1,1+t_{2}^{A}, V^{A}+I\right)+t_{2}^{A}\left(E_{2}^{A}-R_{2}^{A}\right)+t_{3}^{A} E_{3}^{A}-W_{I} I-e_{i}-e_{b}$

(2) $E^{B}\left(1+t_{1}^{B}, 1,1+t_{3}^{B}, u^{B}\right)=R^{B}\left(1+t_{1}^{B}, 1, V^{B}-I\right)+t_{1}^{B}\left(E_{1}^{B}-R_{1}^{B}\right)+t_{3}^{B} E_{3}^{B}+W_{I} I$

(3) $\quad E^{C}\left(1,1,1, u^{C}\right)=R^{C}\left(1, V^{C}\right)$

on interdependence in tariffs (pre-union) between bloc members. Secondly, illegal immigration is a major issue in this paper.

${ }^{4}$ Later, we relax this assumption. 
We assume that revenue function is strictly concave in endowment, $V$, such that $R_{V V}^{i}<0$ for $i=A, B$. Following Ethier (1986) and Bond and Chen (1987), the following assumptions are made. Firms can hire either legal workers and pay $W^{A}$ or illegal workers and pay $W_{I}$. However, if firms are detected to be hiring illegal immigrants, they are fined $\mathrm{z}$ per unit of illegal labor. There is a probability of detection, which depends on the level of internal enforcement. This is denoted as: $p=p\left(e_{i}\right), p^{\prime}>0, p^{\prime \prime}<0$. The expected fine per illegal labor unit hired is $z p$, and on average this is what firms incur above the illegal wage when they hire an illegal immigrant. Competitive firms equate the cost of hiring legal labor to the expected cost of hiring illegal labor.

(4) $W^{A}=W_{I}+z p\left(e_{i}\right)$

Potential migrants in B face the risk of being caught by border enforcement. The expected cost may be denoted as $\beta=\beta\left(e_{b}\right), \beta^{\prime}>0$. The illegal wage rate, net of this cost is: $W_{I}-\beta\left(e_{b}\right)$. Assuming risk neutrality, the equilibrium migration condition dictates that the certainty wage in $\mathrm{B}$ is equated to the net expected wage from migration:

(5) $W^{B}=W_{I}-\beta\left(e_{b}\right)$

\subsection{The effect of trade liberalization on the level of illegal immigration}

This section first shows how tariff policy can affect the level of illegal immigration. Then, we consider a special case where both nations agree to reduce the internal tariffs by the same amount under a Preferential Trade Agreement. With $W^{i}=R_{V}^{i}($.$) for \mathrm{i}=\mathrm{A}$ and $\mathrm{B}$, equations (4) and (5) imply:

$$
R_{V}^{B}\left(1+t_{1}^{B}, 1, V^{B}-I\right)-R_{V}^{A}\left(1,1+t_{2}^{A}, V^{A}+I\right)+\rho\left(e_{i}, e_{b}\right)=0
$$


where, $\rho\left(e_{i}, e_{b}\right) \equiv \beta\left(e_{b}\right)+z p\left(e_{i}\right)$.

Relation-(6) implicitly defines the level of illegal immigration as:

(7) $\quad I=I\left(t_{1}^{B}, t_{2}^{A}, \rho\right)$

Let $D \equiv R_{V V}^{A}+R_{V V}^{B},(D<0)$. Using (6) and (7), the effects of each policy instrument on immigration are:

(8) $I_{1} \equiv \frac{\partial I}{\partial t_{1}^{B}}=\frac{R_{V 1}^{B}}{D}, I_{2} \equiv \frac{\partial I}{\partial t_{2}^{A}}=-\frac{R_{V 2}^{A}}{D}, I_{\rho} \equiv \frac{\partial I}{\partial \rho}=\frac{1}{D}$

Tariffs change the domestic import prices, hence, the wage rates. These in turn affect the incentive for illegal immigration. The precise effect of the tariff on the immigration flow depends on the characteristics of the labor market in the host and source country. That is, how responsive wages are to price changes as well as to changes in the total labor supply. Note that the parameter $\rho$ captures enforcement policy, and we suppress it (for now) to focus on the effect of tariff changes on illegal immigration. Using (7):

(9) $d I=\frac{\partial I}{\partial t_{1}^{B}} d t_{1}^{B}+\frac{\partial I}{\partial t_{2}^{A}} d t_{2}^{A}$

In the following Lemma we discuss a special case where both countries reduce the internal tariffs by the same amount.

Lemma 1. Suppose under the Preferential Trade Agreement, A and B reduce the internal tariff by the same amount while A maintains the initial enforcement policy. Assume that wages in the two nations are positively related to the respective import prices. Illegal immigration increases unambiguously if and only if the wage rate in the source country (B) responds more than the wage rate in the host country (A) to the change in the tariffs. 


\section{Proof:}

$$
d t_{1}^{B}=d t_{2}^{A}=d t<0
$$

Then, from (8) and (9),

(11) $\frac{d I}{d t}=\frac{R_{V 1}^{B}-R_{V 2}^{A}}{D}$

Note that: $\frac{d I}{d t}<0$, if and only if: $R_{V 1}^{B}-R_{V 2}^{A}>0$, in other words, if and only if:

$\frac{\partial w^{B}}{\partial p_{1}}>\frac{\partial w^{A}}{\partial p_{2}}$.

$R_{V 1}$ is the response of the wage rate in a country when the domestic price of good 1 changes due to a change in the tariff on the import of good 1. Goods 1 and 2 are the import goods of B and A, respectively. If the change in the protected (import) sector's price affects the wage rate more in $\mathrm{B}$ than in $\mathrm{A}$, the equal reduction of tariffs by both countries will increase the level of illegal immigration..$^{5}$ This lemma illustrates the importance of incorporating the effects of trade liberalization on illegal immigration in determining overall (trade and enforcement) policy. In the following section, we examine optimal tariff reaction functions in the presence of illegal immigration.

\subsection{The Pre-Agreement Nash Tariff Equilibrium}

This sub-section derives the tariff reaction functions for A and B and describes the Nash tariff equilibrium. Combining (1) and (4) yields:

\footnotetext{
${ }^{5}$ If the labor supply is more inelastic in the source country than in the host country, the change in price due to a tariff leads to a greater change in the wage rate in the source country. This may be a reasonable assumption in the US - Mexico context.
} 


$$
\begin{aligned}
E^{A}\left(1,1+t_{2}^{A}, 1+t_{3}^{A}, u^{A}\right)=R^{A}\left(1,1+t_{2}^{A}, V^{A}+I\right)+t_{2}^{A}\left(E_{2}^{A}-R_{2}^{A}\right)+t_{3}^{A} E_{3}^{A} \\
-I R_{V}^{A}\left(1,1+t_{2}^{A}, V^{A}+I\right)+I z p\left(e_{i}\right)-e_{i}-e_{b}
\end{aligned}
$$

Implicitly, we can write A's utility function as:

$$
u^{A}=u^{A}\left(t_{2}^{A}, t_{3}^{A}, I, e_{i}, e_{b}\right)=u^{A}\left(t_{2}^{A}, t_{3}^{A}, I\left(t_{1}^{B}, t_{2}^{A}, \rho\right), e_{i}, e_{b}\right)
$$

B's tariff enters indirectly into A's utility function through $I$ (.). The change in A's utility is:

(14) $d u^{A}=\frac{\partial u^{A}}{\partial t_{2}^{A}} d t_{2}^{A}+\frac{\partial u^{A}}{\partial I} d I+\frac{\partial u^{A}}{\partial t_{3}^{A}} d t_{3}^{A}+\frac{\partial u^{A}}{\partial e_{b}} d e_{b}+\frac{\partial u^{A}}{\partial e_{i}} d e_{i}$

Using the expenditure - revenue identity (1), we can show:

$$
\frac{\partial u^{A}}{\partial I}=\frac{z p-t_{2}^{A} R_{2 V}^{A}-I R_{V V}^{A}}{D_{u}}, \text { where, } D_{u} \equiv E_{u}^{A}-t_{2}^{A} E_{2 u}^{A}-t_{3}^{A} E_{3 u}^{A}=E_{1 u}^{A}+E_{2 u}^{A}+E_{3 u}^{A}>0,
$$

due to the normality of all goods. The second term in (14) may be interpreted as follows. Nation-A's tariff on good 2 affects $I$ which in turn has three effects captured by the numerator of the right hand side of (15). They are the effects of a unit rise in $I$, and are, respectively, (a) the rise in government fine collections; (b) the expansion (or contraction) of domestic production of good 2 through the Rybczynski effect and the resulting effect on import duty collection; and, (c) the reduction in the legal wage in A leading to a lower wage payment to illegal labor. Relations (14) and (15) endogenize the effects of variability of $I$ and implicitly define the following Nash optimal tax reaction function for $\mathrm{A}$ :

(16) $t_{2}^{A}=t_{2}^{A}\left(t_{1}^{B}, t_{3}^{A}, e_{i}, e_{b}\right)$

A optimally chooses $e_{b}$ and $e_{i}$ by setting $\frac{\partial u^{A}}{\partial e_{b}}=0$ and $\frac{\partial u^{A}}{\partial e_{i}}=0$. This gives us: 


$$
\begin{aligned}
& \beta^{\prime}\left(e_{b}\right)\left(-t_{2}^{A} R_{2 V}^{A}-I R_{V V}^{A}+z p\left(e_{i}\right)\right)=D \\
& z p^{\prime}\left(e_{i}\right)\left[R_{V V}^{B} I-t_{2}^{A} R_{2 V}^{A}+z p\left(e_{i}\right)\right]=D
\end{aligned}
$$

By setting: $\frac{\partial u^{A}}{\partial t_{2}^{A}}=0$, we obtain the reaction function for A.

$$
t_{2}^{A}\left(E_{22}^{A}-R_{22}^{A}\right)+t_{3}^{A} E_{32}^{A}-\frac{R_{V V}^{B} I R_{V 2}^{A}}{D}+\frac{t_{2}^{A} R_{2 V}^{A} R_{2 V}^{A}}{D}-\frac{z p R_{V 2}^{A}}{D}=0
$$

Relation-(19) implicitly defines the Nash tariff reaction function for A. The slope of A's reaction function is:

$$
{\frac{\partial t_{2}^{A}}{\partial t_{1}^{B}}}_{\mid \text {Nash }-A}=-\frac{-R_{V V}^{B} R_{V 2}^{A} R_{V 1}^{B} / D^{2}}{\left(E_{22}^{A}-R_{22}^{A}\right)+R_{2 V}^{A} R_{2 V}^{A}\left(R_{V V}^{A}+2 R_{V V}^{B}\right) / D^{2}}>0
$$

Similarly, we obtain B's reaction function:.

$$
t_{1}^{B}\left[\left(E_{11}^{B}-R_{11}^{B}\right)-\frac{R_{V 1}^{B} R_{V 1}^{B}}{D}\right]+t_{3}^{B} E_{31}^{B}-\frac{\beta R_{V 1}^{B}}{D}+\frac{R_{V}^{B} R_{V 1}^{B}}{D}+\frac{I R_{V 1}^{B}\left(R_{V V}^{A}+2 R_{V V}^{B}\right)}{D}=0
$$

The (inverse of) slope of B's reaction function is:

$$
{\frac{\partial t_{2}^{A}}{\partial t_{1}^{B}}}_{\mid \text {Nash-B }}=-\frac{\left(E_{11}^{B}-R_{11}^{B}\right)+R_{V 1}^{B} R_{V 1}^{B}\left(R_{V V}^{A}+2 R_{V V}^{B}\right) / D^{2}}{-R_{V 2}^{A} R_{V 1}^{B}\left(R_{V V}^{A}+2 R_{V V}^{B}\right) / D^{2}}>0
$$

Relations (17), (18), (19) and (21) can be simultaneously solved to obtain the Nash equilibrium tariff rates for $\mathrm{A}$ and $\mathrm{B}$, as well as the optimal enforcement levels $e_{i}$ and $e_{b}$ for nation-A. The Nash tariff equilibrium is demonstrated in figure-1.

Lemma 2. If the wage rates in both sectors are positively related to their corresponding output prices, then the reaction functions for both countries are upward sloping.

Proof: Shown above in (20) and (22).

In graph 1, a decrease in one nation's tariff is associated with a reduction in the optimal tariff of the other nation. The intersection of the tariff reaction functions gives the second 
best Nash optimal tariff equilibrium. Due to the presence of the external tariffs and illegal immigration, they are positive as shown in the graph 1.

\section{[graph 1]}

\subsection{The effect of a Free Trade Agreement on national welfare}

In this section, we analyze how the national welfare levels of A and B are affected if both nations agree to eliminate their tariffs on each other completely (i.e., completely eliminate import tariffs on goods 1 and 2). ${ }^{6}$ The literature on second best tariffs (in the absence of illegal immigration considerations) suggests that complete liberalization may or may not raise welfare in an already distorted economy. ${ }^{7}$ We explore how illegal immigration affects this conclusion and identify conditions under which complete liberalization will be welfare improving. The following proposition formally states our findings.

Proposition 1. Suppose that the source country's wage rate responds to tariff changes more than the wage rate in the host country, and that goods 2 and 3 (imports for the host country) are complements in consumption. Then, a complete movement to free trade within a bloc consisting of A and B must be welfare improving (if before the FTA they had the same tariff level on their respective intra-bloc imports) while the illegal immigration increases for a given initial enforcement policy.

\footnotetext{
${ }^{6}$ Bond, Riezman, and Syropoulos (2004) consider the welfare effect of FTA when the rest of the world also reacts strategically. While illegal immigration is not considered in their study, they find the complete liberalization within the context of an FTA is not optimal. Our analysis assumes that the trading bloc holds the external tariff rates constant (i.e., the rest of the world practices free trade).

${ }^{7}$ The Kemp-Wan proposition discussed in Ethier and Horn (1984) suggests that the adjustment of the external tariff makes the complete elimination of internal tariff under customs unions welfare improving without harming the rest of the world. Panagariya and Krishna (2002) extends this to the case of an FTA. Throughout the analysis we hold the external tariff constant leaving the examination of the Kemp-Wan type of trade liberalization with the presence of illegal immigration to future research.
} 


\section{Proof:}

Let $d t_{2}^{A}=d t_{1}^{B}=d t<0$. From (14),

(23) $\frac{d u^{A}}{d t}=\frac{\partial u^{A}}{\partial t_{2}^{A}}+\frac{\partial u^{A}}{\partial I}\left(I_{1}+I_{2}\right)$

Suppose $R_{V 1}^{B}>R_{V 2}^{A}$. Then, as we saw in the previous section, $\frac{d I}{d t}<0$, i.e. FTA increases the illegal immigration.

If we evaluate (15) at the Free Trade Agreement, $\left(t_{1}^{B}=0, t_{2}^{A}=0\right), \frac{\partial u^{A}}{\partial I}>0$. Therefore, if ${\frac{\partial u^{A}}{\partial t_{2}^{A}}}_{\mid t=0}<0$, then, $\left.\frac{d u^{A}}{d t}\right|_{\mid t=0}<0$.

Differentiating (12):

$$
\frac{\partial u^{A}}{\partial t_{2}^{A}}=\frac{t_{2}^{A}\left(E_{22}^{A}-R_{22}^{A}\right)+t_{3}^{A} E_{32}^{A}-I R_{V 2}^{A}}{D_{u}}
$$

Evaluated at $t_{2}^{A}=0$,

(25) $\frac{\partial u^{A}}{\left.\partial t_{2}^{A}\right|_{2} ^{A}=0}=\frac{t_{3}^{A} E_{32}^{A}-I R_{V 2}^{A}}{D_{u}}$

Under the conditions of Lemma 2, $I R_{V 2}^{A}>0$. If $E_{32}^{A}<0$ (i.e., goods 2 and 3 are complements in consumption), the right hand side of (25) must be negative. This ensures that the FTA is welfare improving because it implies that the right hand side of (23) is negative.

If goods 2 and 3 are complements, as the tariff on good 2 is reduced, consumers demand more of it as well as of good 3. This raises the tariff revenue collection from good 3. Secondly, the reduction of tariff on good 2 reduces A's wage rate. This results 
in lower payments to illegal immigrants and translates to a gain for $\mathrm{A}$. This is the second term in the numerator in (25). Under complementarity, both these effects raise A's real income and its welfare rises due to the liberalization. If goods 2 and 3 are substitutes, the welfare implication of the FTA is in general ambiguous and depends on the balance of the tariff revenue effect and the wage earnings effect.

The second term in (23) is negative. From Lemma 1 we see that mutual trade liberalization raises illegal immigration. This lowers the immigrant wage income, while raising the expected fine collections from firms hiring them. Thus, in the presence of endogenous illegal immigration, an FTA is more likely to be welfare enhancing. ${ }^{8}$

\subsection{Is multilateral trade liberalization compatible with bilateral trade}

\section{liberalization?}

In this section, we examine whether A would like to reduce the external tariff (i.e., the tariff on good 3) as a credible pre-commitment to multilateral trade liberalization. First, we see how the reaction function of $\mathrm{A}$ is affected by the reduction of the tariff on good 3. Second, we examine whether reducing the tariff on good 3 is welfare improving for A. ${ }^{9}$ From (20) and (22), the slopes of the reaction functions do not change in response to the change in the tariff on good on 3. Denoting the left hand side of (19) as $\Phi^{A}$,

\footnotetext{
${ }^{8}$ It contradicts general public view that an increase in illegal immigration worsens the national welfare of the host country. Here, readers should keep in mind that we focus on the economic analysis of illegal immigration. Associated social and humanitarian issues are important, but they are beyond the scope of this paper.

${ }^{9}$ Bond, Syropoulos, and Winters (2001) discuss how trade liberalization in a customs union affects the multilateral trading process. They find that intra-bloc trade liberalization which requires the reduction of the external tariff is negatively associated with the elasticity of substitution between member and nonmember goods.
} 
(26) $\frac{\partial t_{2}^{A}}{\partial t_{3}^{A}}=-\frac{E_{32}^{A}}{\partial \Phi^{A} / \partial t_{2}^{A}}$

The denominator of (26) can be assumed negative if the second order condition $\partial^{2} u^{A} /\left(\partial t_{2}^{A}\right)^{2}$ is sufficiently large as is shown in the Appendix. Thus, if good 2 and 3 are substitutes (i.e., $E_{32}^{A}>0$ ), the reduction in $t_{3}^{A}$ will shift A's reaction function down as described in the graph 2. On the other hand, if $E_{32}^{A}<0$, A's reaction function shifts up.

\section{[graph 2]}

Let us consider the case where the goods are substitutes. Given B's reaction function, A knows that if it can pre-commit to a lower $t_{3}^{A}$, it would lead to a reduction in $t_{1}^{B}$. The effect of $t_{1}^{B}$ on A's utility is (from relation-14):

(27) $\frac{\partial u^{A}}{\partial t_{1}^{B}}=-\frac{t_{2}^{A} R_{V 2}^{A} R_{V 1}^{B}}{D D_{u}^{A}}-\frac{I R_{V V}^{A} R_{V 1}^{B}}{D D_{u}^{A}}+\frac{z p R_{V 1}^{B}}{D D_{u}^{A}}$

If $\frac{\partial u^{A}}{\partial t_{1}^{B}}<0$, the reduction of $t_{3}^{A}$ is welfare enhancing for A. In other word, multilateral trade liberalization is compatible with PTA if and only if: $t_{2}^{A}>\frac{z p-I R_{V V}^{A}}{R_{V 2}^{A}}$

Intuitively, if the initial internal tariff is high enough to start with, both multilateral trade liberalization and bilateral trade liberalization such as PTA are compatible with each other and lead to a movement in the direction of global free trade.

Proposition 2. Reduction of tariff on good-3 leads to lower (higher) Nash equilibrium tariffs for A and B's intra-bloc trade if good 2 and 3 are substitutes (complements). If the initial internal tariff is sufficiently high, reducing the external tariff is also welfare 
improving for nation-A given good 2 and 3 are substitutes. In this case, the multilateral trade liberalization process is compatible with bilateral trade liberalization. Furthermore, if the size of wage response in the host country is at least as large as that in the source country, illegal immigration decreases due to reduction of tariff on good-3.

Proof: The text preceding the proposition constitutes the proof.

\section{Large Open Economy}

This section extends the previous analysis to the case of a union of two large nations. The analysis is more complicated because tariffs for A and B affect the world prices, which in turn affect the level of illegal immigration. We start by defining the expenditure-revenue equation for $\mathrm{A}, \mathrm{B}$ and $\mathrm{C}$ and then proceed to analyze how tariffs affect the border prices. We discuss how the second best Nash optimal tariff equilibrium may differ in the context of a large open economy. Using the price of good-3 as the numeraire, the expenditure-revenue functions for the three nations are:

$$
\begin{aligned}
& E^{A}\left(p_{1}, p_{2}+t_{2}^{A}, 1+t_{3}^{A}, u^{A}\right)=R^{A}\left(p_{1}, p_{2}+t_{2}^{A}, V^{A}+I\right)+t_{2}^{A}\left(E_{2}^{A}-R_{2}^{A}\right)+t_{3}^{A} E_{3}^{A}-W_{I} I-e_{i}-e_{b} \\
& E^{B}\left(p_{1}+t_{1}^{B}, p_{2}, 1+t_{3}^{B}, u^{B}\right)=R^{B}\left(p_{1}+t_{1}^{B}, p_{2}, V^{B}-I\right)+t_{1}^{B}\left(E_{1}^{B}-R_{1}^{B}\right)+t_{3}^{B} E_{3}^{B}+W_{I} I \\
& E^{C}\left(p_{1}, p_{2}, 1, u^{C}\right)=R^{C}\left(1, V^{C}\right)
\end{aligned}
$$

The goods market equilibrium conditions are:

$$
E_{1}^{A}\left(p_{1}, p_{2}+t_{2}^{A}, 1+t_{3}^{A}, u^{A}\right)+E_{1}^{B}\left(p_{1}+t_{1}^{B}, p_{2}, 1+t_{3}^{B}, u^{B}\right)
$$$$
+E_{1}^{C}\left(p_{1}, p_{2}, 1, u^{C}\right)=R_{1}^{A}\left(p_{1}, p_{2}+t_{2}^{A}, V^{A}+I\right)+R_{1}^{B}\left(p_{1}+t_{1}^{B}, p_{2}, V^{B}-I\right)+R_{1}^{C}\left(p_{1}, p_{2}, 1, V^{C}\right)
$$ 


$$
E_{2}^{A}\left(p_{1}, p_{2}+t_{2}^{A}, 1+t_{3}^{A}, u^{A}\right)+E_{2}^{B}\left(p_{1}+t_{1}^{B}, p_{2}, 1+t_{3}^{B}, u^{B}\right)
$$

$+E_{2}^{C}\left(p_{1}, p_{2}, 1, u^{C}\right)=R_{2}^{A}\left(p_{1}, p_{2}+t_{2}^{A}, V^{A}+I\right)+R_{2}^{B}\left(p_{1}+t_{1}^{B}, p_{2}, V^{B}-I\right)+R_{2}^{C}\left(p_{1}, p_{2}, 1, V^{C}\right)$

Walras' law assures that the market for good 3 is in equilibrium. The illegal immigration level is affected not only by tariffs but also through terms of trade effects. The labor market equilibrium condition with endogenous prices is

$$
R_{V}^{B}\left(p_{1}+t_{1}^{B}, p_{2}, V^{B}-I\right)-R_{V}^{A}\left(p_{1}, p_{2}+t_{2}^{A}, V^{A}+I\right)+\rho\left(e_{i}, e_{b}\right)=0
$$

Thus, illegal immigration is defined as:

$$
I=I\left(p_{1}, p_{2}, t_{2}^{A}, t_{1}^{B}, \rho\right)
$$

The change in illegal immigration is:

$$
d I=I_{1} d p_{1}+I_{2} d p_{2}+I_{3} d t_{2}^{A}+I_{4} d t_{1}^{B}+I_{\rho} d \rho
$$

In the present context, (12) may be written as:

$$
\begin{aligned}
& \text { (36) } E^{A}\left(p_{1}, p_{2}+t_{2}^{A}, 1+t_{3}^{A}, u^{A}\right)-R^{A}\left(p_{1}, p_{2}+t_{2}^{A}, V^{A}+I\right)-t_{2}^{A}\left(E_{2}^{A}-R_{2}^{A}\right) \\
& -t_{3}^{A} E_{3}^{A}+I R_{V}^{A}\left(p_{1}, p_{2}+t_{2}^{A}, V^{A}+I\right)+z p I+e_{i}+e_{b}=0
\end{aligned}
$$

Relation-(36) implicitly defines A's utility as:

$$
u^{A}=u^{A}\left(p_{1}, p_{2}, t_{2}^{A}, t_{3}^{A}, I\left(p_{1}, p_{2}, t_{2}^{A}, t_{1}^{B}, \rho\right), e_{i}, e_{b}\right)
$$

The difference from the previous small economy cases [see relation-(13) earlier] is that we have prices in the utility function. For B:

$$
-t_{3}^{B} E_{3}^{B}-R_{V}^{A}\left(p_{1}, p_{2}+t_{2}^{A}, V^{A}+I\right) I+z p I=0
$$

Thus, B's utility can be written implicitly as:

$$
u^{B}=u^{B}\left(p_{1}, p_{2}, t_{1}^{B}, t_{3}^{B}, t_{2}^{A}, I\left(p_{1}, p_{2}, t_{2}^{A}, t_{1}^{B}, \rho\right), e_{b}\right)
$$


Next, we find how prices are related to the internal tariffs. This is crucial in highlighting the strategic tariff policy of a PTA because members of a trading bloc negotiate over tariffs with a major issue being their intra-bloc and external terms of trade effects.

Proposition 3. When the own price effects dominate the cross price effects of tariff changes and the wage rate is more responsive to the change in the price of the import good (compared to the price of the export good), mutual reductions of the intra-bloc tariffs improve both A and B's terms of trade with respect to C. The illegal immigration may increase or decrease depending on how wages respond in each country.

Proof: The proof is provided in the Appendix at the end.

Now, we briefly describe the Nash tariff equilibrium in the large union case. Using (37):

$$
\begin{aligned}
& \frac{d u^{A}}{d t_{2}^{A}}=\left(u_{1}^{A}+u_{5}^{A} I_{1}\right) \frac{d p_{1}}{d t_{2}^{A}}+\left(u_{2}^{A}+u_{5}^{A} I_{2}\right) \frac{d p_{2}}{d t_{2}^{A}}+\left(u_{3}+u_{5}^{A} I_{4}\right)=0 ; \text { where, } \\
& u_{1}^{A}=\frac{-\left(E_{1}^{A}-R_{1}^{A}\right)+t_{2}^{A}\left(E_{21}^{A}-R_{21}^{A}\right)+t_{3}^{A} E_{31}^{A}-I R_{V 1}^{A}}{D_{u}^{A}} \\
& u_{5}^{A} \equiv \frac{\partial u^{A}}{\partial I}=\frac{-t_{2}^{A} R_{V 2}^{A}-I R_{V V}^{A}-z p}{D_{u}^{A}} \\
& I_{1}=-\frac{R_{V 1}^{A}-R_{V 1}^{B}}{D}, I_{2}=-\frac{R_{V 2}^{A}-R_{V 2}^{B}}{D} \\
& u_{2}^{A}=\frac{-\left(E_{2}^{A}-R_{2}^{A}\right)+t_{2}^{A}\left(E_{22}^{A}-R_{22}^{A}\right)+t_{3}^{A} E_{32}^{A}-I R_{V 2}^{A}}{D_{u}^{A}} \\
& \frac{d u^{B}}{d t_{1}^{B}}=\left(u_{1}^{B}+u_{5}^{A} I_{1}\right) \frac{d p_{1}}{d t_{1}^{B}}+\left(u_{2}^{A}+u_{5}^{A} I_{2}\right) \frac{d p_{2}}{d t_{1}^{B}}+\left(u_{3}+u_{5}^{A} I_{3}\right)=0
\end{aligned}
$$

The third term on the right hand side of (40) is the Nash condition in the case of a small economy, while the first two terms are the additional terms due to endogenous prices. 
The latter terms capture how A uses strategic tariff policies to manipulate terms of trade to its benefit.

$$
u_{2}^{A}=-\frac{\partial u^{A}}{\partial p_{2}}=\frac{-\left(E_{2}^{A}-R_{2}^{A}\right)+t_{2}^{A}\left(E_{22}^{A}-R_{22}^{A}\right)+t_{3}^{A} E_{32}^{A}-I R_{V 2}^{A}}{D_{u}}
$$

where, $E_{2}^{A}-R_{2}^{A}>0$, as A is an importer of good 2 .

Thus, $u_{2}^{A}<0$ if $R_{V 2}^{A}>0$ and $t_{3}^{A} E_{32}^{A}$ is not large and positive. The sign of $\frac{\partial p_{2}}{\partial t_{2}^{A}}$ is in general indeterminate though we have shown that the mutual tariff reductions by A and B would decrease $p_{2}$. However, if we assume $\frac{\partial p_{2}}{\partial t_{2}^{A}}<0$, then, $u_{2}^{A} \frac{\partial p_{2}}{\partial t_{2}^{A}}>0$. This tends to raise the second best tariff of A. If $R_{V 2}^{B}<R_{V 2}^{A}$, the effect is further accentuated. On the other hand, if $R_{V 2}^{B}>R_{V 2}^{A}$ :

$$
\frac{\left(R_{V 2}^{B}-R_{V 2}^{A}\right)}{\beta^{\prime} D_{u}}>0
$$

In this case, the terms $\frac{\left(R_{V 2}^{B}-R_{V 2}^{A}\right)}{\beta^{\prime} D_{u}} \frac{\partial p_{2}}{\partial t_{2}^{A}}<0$ and $u_{2}^{A} \frac{\partial p_{2}}{\partial t_{2}^{A}}>0$ pull in opposite directions.

The import tariff on good 2 tends to keep the international price of good 2 low. However, this has adverse effect on the domestic wage rate. Thus, the optimal strategic tariff has to balance the terms of trade benefit and its impact on the wage rate. In the large economy case, the slope of the optimal tariff reaction function can either positive or negative, and depends on the relative magnitude of the different terms presented above. 


\section{Conclusion}

The paper focuses on the intra-bloc trade negotiation process in the presence of illegal immigration. Our findings comprise largely of three parts. First, we show that when the interaction between tariff policy and illegal immigration is ignored, trade liberalization may lead to an increase in illegal immigration. This establishes the importance of incorporating both issues simultaneously in the negotiations. Second, we identify conditions under which an FTA (i.e., complete elimination of tariffs within the bloc) is likely to be welfare improving in the presence of illegal immigration. Finally, we consider terms of trade effects of tariff negotiations and how they will in turn affect the immigration problem. 


\section{Graph 1 The internal Nash tariff Equilibrium}

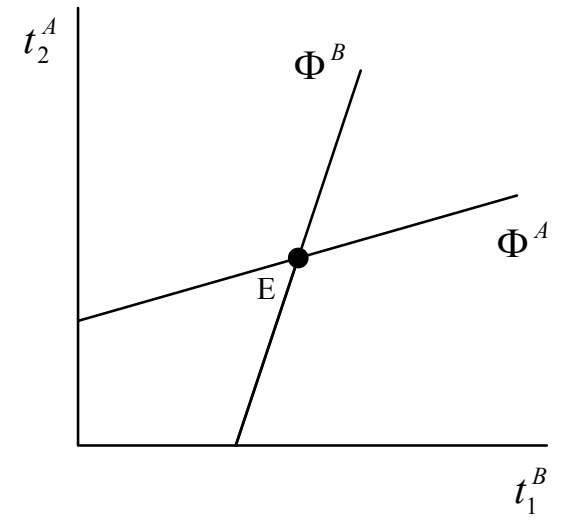

$$
\begin{aligned}
& \Phi^{A}: \text { A's Reaction function } \\
& \Phi^{B}: \text { B's Reaction function } \\
& \mathrm{E}: \text { Nash Equilibrium }
\end{aligned}
$$

\section{Graph 2 The effect of the external tariff reduction}

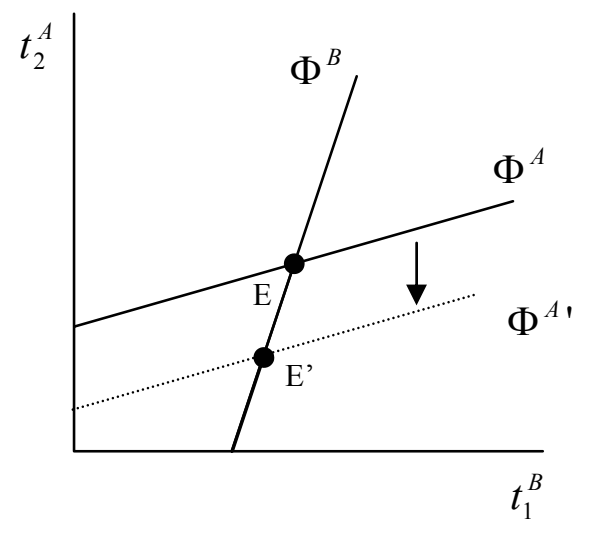

$\Phi^{A \prime}$ : A's Reaction function after reduction in $t_{3}^{A}$ E' : new Nash Equilibrium 


\section{Appendix}

1. Deriving A's Optimal Tariff Reaction Function (Small Union Case):

Total differential of A's utility function is:

(A1) $D_{u}^{A} d u^{A}=\left[t_{2}^{A}\left(E_{22}^{A}-R_{22}^{A}\right)+t_{3}^{A} E_{32}^{A}-I R_{V 2}^{A}+\frac{t_{2}^{A} R_{2 V}^{A} R_{2 V}^{A}}{D}+\frac{I R_{V V}^{A} R_{V 2}^{A}}{D}-\frac{z p\left(e_{i}\right) R_{V 2}^{A}}{D}\right] d t_{2}^{A}$

$+\left[t_{2}^{A} E_{23}^{A}+t_{3}^{A} E_{33}^{A}\right] d t_{3}^{A}$

$+\left[-\frac{t_{2}^{A} R_{V 2}^{A} R_{V 1}^{B}}{D}-\frac{I R_{V V}^{A} R_{V 1}^{B}}{D}+\frac{z p\left(e_{i}\right) R_{V 1}^{B}}{D}\right] d t_{1}^{B}$

$+\left[z I p^{\prime}-1-\frac{t_{2}^{A} R_{V 2}^{A} z p^{\prime}}{D}-\frac{I R_{V V}^{A} z p^{\prime}}{D}+\frac{z p z p^{\prime}}{D}\right] d e_{i}$

$+\left[-\frac{\beta^{\prime} t_{2}^{A} R_{2 V}^{A}}{D}-\frac{I R_{V V}^{A} \beta^{\prime}}{D}-\frac{z p \beta^{\prime}}{D}-1\right] d e_{b}$

2. Substitutability of good 2 and 3 in Proposition 2:

From equation-(6), one notes that illegal immigration is independent of the external tariffs. From the optimal enforcement policy conditions, (17) and (18), we find that the optimal enforcement policy instruments depend on the internal tariffs of A and B.

However, they are independent of the external tariffs. We use this observation to derive the effect of changes in the external tariffs on the tariff reaction functions.

Denote $\Phi^{A}=t_{2}^{A}\left(E_{22}^{A}-R_{22}^{A}\right)+t_{3}^{A} E_{32}^{A}-\frac{R_{V V}^{B} I R_{V 2}^{A}}{D}+\frac{t_{2}^{A} R_{2 V}^{A} R_{2 V}^{A}}{D}-\frac{z p R_{V 2}^{A}}{D}$ in (19). 


$$
\begin{aligned}
& \frac{\partial t_{2}^{A}}{\partial t_{3}^{A}}=-\frac{\partial \Phi^{A} / \partial t_{3}^{A}}{\partial \Phi^{A} / \partial t_{2}^{A}}=-\frac{E_{32}^{A}}{\left(E_{22}^{A}-R_{22}^{A}\right)+R_{2 V}^{A} R_{2 V}^{A}\left(R_{V V}^{A}+2 R_{V V}^{B}\right) / D^{2}-z p^{\prime}\left(1 / D^{2}\right) R_{V 2}^{A} \partial e_{i} / \partial t_{2}^{A}} \\
& =-\frac{E_{32}^{A}}{\left(E_{22}^{A}-R_{22}^{A}\right)+R_{2 V}^{A} R_{2 V}^{A}\left(R_{V V}^{A}+2 R_{V V}^{B}\right) / D^{2}-z p^{\prime}\left(1 / D^{)} R_{V 2}^{A} \frac{\left[z p^{\prime}\left(-R_{V V}^{B} R_{V 2}^{A} / D^{\left.-R_{V 2}^{A}\right)}\right)\right]}{\left[z p^{\prime \prime}\left(R_{V V}^{B} I-t_{2}^{A} R_{V 2}^{A}+z p\right)+z p^{\prime}\left(R_{V V}^{B} z p^{\prime} / D^{+} z p^{\prime}\right)\right]}\right.}
\end{aligned}
$$

The first two terms in the denominator represent the second order condition for optimal $t_{2}^{A}$ and therefore their sign is unambiguously negative. If these two terms dominate the third term, then the whole denominator is negative. In this case, the sign of $\frac{\partial t_{2}^{A}}{\partial t_{3}^{A}}$ is the same as the sign of $E_{32}^{A}$. If goods 2 and 3 are substitutes, the sign of $\frac{\partial t_{2}^{A}}{\partial t_{3}^{A}}$ is positive and a reduction of $t_{3}^{A}$ leads to a downward shift of A's reaction function. Graph 2 depicts this case showing that both $t_{2}^{A}$ and $t_{1}^{B}$ decline, although the former decreases more than the later. Given equations (8) and (9), if the size of the wage response in the host country is at least as large as that in the source country, i.e. $\frac{\partial w^{A}}{\partial p_{2}}>\frac{\partial w^{B}}{\partial p_{1}}$, illegal immigration decreases due to reduction of tariff on good-3.

\section{Proof of Proposition 3:}

Totally differentiating (31) and (32) and assuming quasi-linear utility, we obtain: 


$$
\left[\begin{array}{cc}
\alpha_{1}+\frac{\left(R_{V 1}^{A}-R_{V 1}^{B}\right)^{2}}{D} & \beta+\frac{\left(R_{V 1}^{A}-R_{V 1}^{B}\right)\left(R_{V 2}^{A}-R_{V 2}^{B}\right)}{D} \\
\beta+\frac{\left(R_{V 1}^{A}-R_{V 1}^{B}\right)\left(R_{V 2}^{A}-R_{V 2}^{B}\right)}{D} & \alpha_{2}+\frac{\left(R_{V 2}^{A}-R_{V 2}^{B}\right)^{2}}{D}
\end{array}\right]\left[\begin{array}{l}
d p_{1} \\
d p_{2}
\end{array}\right]
$$

$$
=\left[\begin{array}{c}
{\left[\left(R_{12}^{A}-E_{12}^{A}\right)-\frac{\left(R_{V 1}^{A}-R_{V 1}^{B}\right) R_{V 2}^{A}}{D}\right] d t_{2}^{A}+\left[\left(R_{11}^{B}-E_{11}^{B}\right)+\frac{\left(R_{V 1}^{A}-R_{V 1}^{B}\right) R_{V 1}^{B}}{D}\right] d t_{1}^{B}} \\
{\left[\left(R_{22}^{A}-E_{22}^{A}\right)-\frac{\left(R_{V 2}^{A}-R_{V 2}^{B}\right) R_{V 2}^{A}}{D}\right] d t_{2}^{A}+\left[\left(R_{21}^{B}-E_{21}^{B}\right)+\frac{\left(R_{V 2}^{A}-R_{V 2}^{B}\right) R_{V 1}^{B}}{D}\right] d t_{1}^{B}}
\end{array}\right]
$$

where, $\alpha_{1} \equiv E_{11}^{A}+E_{11}^{B}+E_{11}^{C}-R_{11}^{A}-R_{11}^{B}-R_{11}^{C}, \alpha_{2} \equiv E_{22}^{A}+E_{22}^{B}+E_{22}^{C}-R_{22}^{A}-R_{22}^{B}-R_{22}^{C}$, and $\beta \equiv E_{12}^{A}+E_{12}^{B}+E_{12}^{C}-R_{12}^{A}-R_{12}^{B}-R_{12}^{C}$.

$$
|H| \equiv\left|\begin{array}{cc}
\alpha_{1}+\frac{\left(R_{V 1}^{A}-R_{V 1}^{B}\right)^{2}}{D} & \beta+\frac{\left(R_{V 1}^{A}-R_{V 1}^{B}\right)\left(R_{V 2}^{A}-R_{V 2}^{B}\right)}{D} \\
\beta+\frac{\left(R_{V 1}^{A}-R_{V 1}^{B}\right)\left(R_{V 2}^{A}-R_{V 2}^{B}\right)}{D} & \alpha_{2}+\frac{\left(R_{V 2}^{A}-R_{V 2}^{B}\right)^{2}}{D}
\end{array}\right|
$$$$
=\alpha_{1} \alpha_{2}-\beta^{2}+\alpha_{2} \frac{\left(R_{V 1}^{A}-R_{V 1}^{B}\right)^{2}}{D}+\alpha_{1} \frac{\left(R_{V 2}^{A}-R_{V 2}^{B}\right)^{2}}{D}-2 \beta \frac{\left(R_{V 1}^{A}-R_{V 1}^{B}\right)\left(R_{V 2}^{A}-R_{V 2}^{B}\right)}{D}
$$

$|H|>0$ if $R_{2 V}^{A}>R_{2 V}^{B}$ and $R_{1 V}^{B}>R_{1 V}^{A},\left|\alpha_{1}\right|>\beta,\left|\alpha_{2}\right|>\beta$, and $\left|R_{V 1}^{A}-R_{V 1}^{B}\right|=\left|R_{V 2}^{A}-R_{V 2}^{B}\right|$

The first two conditions imply that the rise in the price of the export good raises the wage rate by more than the rise in the price of the import good does. The third and fourth conditions can be interpreted as the relationship between the own price effect and the cross price effect. By freezing $d t_{1}^{B}$ and using Cramer's rule: 
(A4) $\frac{\partial p_{1}}{\partial t_{2}^{A}}=\left[\begin{array}{l}\alpha_{2}\left[\left(R_{12}^{A}-E_{12}^{A}\right)-\frac{\left.\left(R_{V 1}^{A}-R_{V 1}^{B}\right) R_{V 2}^{A}\right]}{D}\right]-\beta\left[\left(R_{22}^{A}-E_{22}^{A}\right)-\frac{\left.\left(R_{V 2}^{A}-R_{V 2}^{B}\right) R_{V 2}^{A}\right]}{D}\right] \\ +\frac{\left(R_{V 2}^{A}-R_{V 2}^{B}\right)^{2}\left(R_{12}^{A}-E_{12}^{A}\right)}{D}-\frac{\left(R_{22}^{A}-E_{22}^{A}\right)\left(R_{V 1}^{A}-R_{V 1}^{B}\right)\left(R_{V 2}^{A}-R_{V 2}^{B}\right)}{D}\end{array}\right] / H \mid$

(A5) $\frac{\partial p_{2}}{\partial t_{2}^{A}}=\left[\begin{array}{l}\alpha_{1}\left[\left(R_{22}^{A}-E_{22}^{A}\right)-\frac{\left.\left(R_{V 2}^{A}-R_{V 2}^{B}\right) R_{V 2}^{A}\right]}{D}\right]-\beta\left[\left(R_{12}^{A}-E_{12}^{A}\right)-\frac{\left(R_{V 1}^{A}-R_{V 1}^{B}\right) R_{V 2}^{A}}{D}\right] \\ +\frac{\left(R_{V 1}^{A}-R_{V 1}^{B}\right)^{2}\left(R_{22}^{A}-E_{22}^{A}\right)}{D}-\frac{\left(R_{12}^{A}-E_{12}^{A}\right)\left(R_{V 1}^{A}-R_{V 1}^{B}\right)\left(R_{V 2}^{A}-R_{V 2}^{B}\right)}{D}\end{array}\right] /|H|$

Similarly, by freezing $d t_{2}^{A}$ :

(A6) $\frac{\partial p_{1}}{\partial t_{1}^{B}}=\left[\begin{array}{l}\alpha_{2}\left[\left(R_{11}^{B}-E_{11}^{B}\right)-\frac{\left.\left(R_{V 1}^{A}-R_{V 1}^{B}\right) R_{V 1}^{A}\right]}{D}\right]-\beta\left[\left(R_{21}^{A}-E_{21}^{A}\right)-\frac{\left.\left(R_{V 2}^{A}-R_{V 2}^{B}\right) R_{V 1}^{B}\right]}{D}\right] \\ +\frac{\left(R_{V 2}^{A}-R_{V 2}^{B}\right)^{2}\left(R_{11}^{B}-E_{11}^{B}\right)}{D}-\frac{\left(R_{21}^{B}-E_{21}^{B}\right)\left(R_{V 1}^{A}-R_{V 1}^{B}\right)\left(R_{V 2}^{A}-R_{V 2}^{B}\right)}{D}\end{array}\right] /|H|$

(A7) $\frac{\partial p_{2}}{\partial t_{1}^{B}}=\left[\begin{array}{l}\alpha_{1}\left[\left(R_{21}^{B}-E_{21}^{B}\right)-\frac{\left(R_{V 2}^{A}-R_{V 2}^{B}\right) R_{V 1}^{B}}{D}\right]-\beta\left[\left(R_{11}^{B}-E_{11}^{B}\right)-\frac{\left.\left(R_{V 1}^{A}-R_{V 1}^{B}\right) R_{V 1}^{B}\right]}{D}\right] \\ +\frac{\left(R_{V 1}^{A}-R_{V 1}^{B}\right)^{2}\left(R_{21}^{B}-E_{21}^{B}\right)}{D}-\frac{\left(R_{11}^{B}-E_{11}^{B}\right)\left(R_{V 1}^{A}-R_{V 1}^{B}\right)\left(R_{V 2}^{A}-R_{V 2}^{B}\right)}{D}\end{array}\right]|H|$

When $\frac{\partial p_{2}}{\partial t_{2}^{A}}<0$, B negotiates with A to reduce A's tariff, $t_{2}^{A}$. Similarly, when $\frac{\partial p_{1}}{\partial t_{1}^{B}}<0$,

A negotiates with B to obtain a reduction in $t_{1}^{B}$. When both nations mutually reduce their 
internal tariffs by the same amounts, its impact on the terms of trade for A (in terms of good 3) can be shown as:

$$
|H|\left(\frac{\partial p_{1}}{\partial t_{2}^{A}}+\frac{\partial p_{1}}{\partial t_{1}^{B}}\right)=\alpha_{2}\left[\left(R_{12}^{A}-E_{12}^{A}\right)+\left(R_{11}^{B}-E_{11}^{B}\right)\right]+\alpha_{2} \frac{\left(R_{V 1}^{A}-R_{V 1}^{B}\right)\left(R_{V 1}^{B}-R_{V 2}^{A}\right)}{D}
$$

$-\beta\left[\left(R_{22}^{A}-E_{22}^{A}\right)+\left(R_{21}^{B}-E_{21}^{B}\right)\right]-\beta \frac{\left(R_{V 2}^{A}-R_{V 2}^{B}\right)\left(R_{V 1}^{B}-R_{V 2}^{A}\right)}{D}$

$+\frac{\left(R_{V 2}^{A}-R_{V 2}^{B}\right)^{2}}{D}\left[\left(R_{11}^{B}-E_{11}^{B}\right)+\left(R_{12}^{A}-E_{12}^{A}\right)\right]-\frac{\left(R_{V 1}^{A}-R_{V 1}^{B}\right)\left(R_{V 2}^{A}-R_{V 2}^{B}\right)}{D}\left[\left(R_{21}^{B}-E_{21}^{B}\right)+\left(R_{22}^{A}-E_{22}^{A}\right)\right]$

Relation (A8) implies that if $|H|>0$ :

$$
\begin{aligned}
& \frac{\partial p_{1}}{\partial t_{2}^{A}}+\frac{\partial p_{1}}{\partial t_{1}^{B}}<0 ; \\
& \text { if }\left[\alpha_{2}\left(R_{V 1}^{A}-R_{V 1}^{B}\right)-\beta\left(R_{V 2}^{A}-R_{V 2}^{B}\right)\right]\left(R_{V 1}^{B}-R_{V 2}^{A}\right)>0, R_{V 2}^{A}-R_{V 2}^{B}>0, \text { and } \\
& R_{V 1}^{A}-R_{V 1}^{B}<0 .
\end{aligned}
$$

Similarly, we can show that the mutual tariff reduction improves B's terms of trade

$$
\begin{aligned}
& \frac{\partial p_{2}}{\partial t_{2}^{A}}+\frac{\partial p_{2}}{\partial t_{1}^{B}}<0 \text { if }\left[\alpha_{1}\left(R_{V 2}^{A}-R_{V 2}^{B}\right)-\beta\left(R_{V 1}^{A}-R_{V 1}^{B}\right)\right]\left(R_{V 1}^{B}-R_{V 2}^{A}\right)>0, R_{V 2}^{A}-R_{V 2}^{B}>0, \\
& \text { and } R_{V 1}^{A}-R_{V 1}^{B}<0 .
\end{aligned}
$$

The impact on illegal immigration can be written as

$d I=I_{1}\left(\frac{\partial p_{1}}{\partial t_{2}^{A}}+\frac{\partial p_{1}}{\partial t_{1}^{B}}\right) d t+I_{2}\left(\frac{\partial p_{2}}{\partial t_{2}^{A}}+\frac{\partial p_{2}}{\partial t_{1}^{B}}\right) d t+\left(I_{3}+I_{4}\right) d t$ where $d t=d t_{2}^{A}=d t_{1}^{B}<0$

From above discussion, if $I_{1}>0, I_{2}>0, I_{3}+I_{4}<0$, then, the mutual tariff reduction increases the illegal immigration. The conditions can be rephrased as $R_{V 1}^{B}>R_{V 2}^{A}, R_{V 1}^{A}>R_{V 1}^{B}, R_{V 2}^{A}>R_{V 2}^{B}$. 


\section{Chapter 3}

\section{The impact of Trade and Factor Flows on Domestic Taxation}

\section{Introduction}

Over the past period, industrial countries have become more integrated with each other and into the world economy. They engage in international trade more freely and more capital flows between them, although the degree at which each economy is connected with the outside economy differs among the industrial countries. At the same time, each economy tries to maintain autonomous fiscal policy in the midst of globalization. Financing publicly provided goods and services and redistribution policy through taxation is crucial for each autonomous jurisdiction. While the distinction in the tax system among the countries is large, so is the distinction of the tax rates. Mendoza, Razin, Tesar (1994) studied the average effective tax rates on labor, capital, and consumption for OECD countries between 1965 and 1988. The average effective tax rates represent the tax burden in a representative agent model as well as the magnitude of tax distortion in each market. According to their calculation, the level of the tax rates and the time trends are seen as quite different among the sample countries.

For example, the level of consumption tax in the United States and Japan is maintained low throughout the sample period. On the other hand, European countries and Canada show high levels. The trends of consumption tax also differ among countries. France, the United States, and Japan exhibit a stable trend; while the United Kingdom, Canada, and Italy exhibit decreasing rates up until the end of 1970's and rising afterward. For the labor tax, all the examined countries show a rising trend, but with different 
speeds. For instance, the U.S. labor tax rate rose until 1982, but, was stable afterward. France, Italy, and Japan exhibit a steady increase throughout the period. Canada shows a rise and fall as does the United Kingdom. The difference among the countries is also seen in the capital tax as well though as Mendoza etc. (1994) noted, it is more prone to the business cycles that the countries experience.

This paper aims to explore such differences in domestic taxation among the industrial countries. More specifically, we examine how the trade of goods and services and the flows of labor and capital affect the average effective tax rates on labor, capital and consumption. This paper aims to provide insights of why different countries, whose trade volume and factor flows vary, exhibited different dynamics of domestic taxation.

The various literatures have introduced the possible link between economic integration and domestic taxation. They claimed that the trade in goods and services may alter the elasticity of capital and labor, and hence, change the optimal tax rates for capital and labor. Economic integration encourages the flows of capital and labor between countries. This may directly alter the taxation on capital and labor as the tax bases are influenced. While the various channels at which domestic taxation might be affected have been discussed, the empirical scrutiny in this paper finds these channels rather weak, particularly the capital and labor tax rate. The features in economic integration such as international trade and factor flows across countries are found having no influence on the capital and labor tax rates. Instead, the paper finds strong evidence that economic integration with more net inflow of labor and capital and international trade is associated with lower consumption tax rates. While government may be simply shifting the tax burden away from consumers, this channel has not been explored in the literature, 
especially the link between the consumption tax rate and factor flows. The essay urges further investigation on why factor flows influence the consumption tax.

Section 2 introduces some previous literatures in both theoretical and empirical studies to illustrate the link between economic integration and domestic taxation. Section 3 provides the description of Data and the variables used in this study. Section 4

discusses some empirical specification issues. Section 5 explains the results, and Section 6 concludes.

\section{The literature review}

In this section, we introduce some of the theoretical and empirical literature which explains the link between the features of economic integration and domestic taxation. In the later analysis, we use the effective tax rates as measurements of domestic taxes, which have developed rich arguments in the recent literature of measuring taxes. Therefore, we start with the summary of the recent development of the effective tax rate literature.

\subsection{The effective tax rates}

Previously, researchers have developed the measurements of effective tax rates in various ways to answer critical economic questions such as what is the overall burden of taxes and what is the magnitude of tax distortions. The initial study on the effective tax rates focused on the capital income. King and Fullerton (1984) brought a main development in the literature of effective tax rates on earnings stemming from capital, 
which was based on the earlier research on the investment theory by Jorgenson (1963) and the following researches by Hall and Jorgenson (1967) and King (1974). The KingFullerton approach was criticized due to the complexity of calculation and the number of assumptions required. Responding to this criticism, Mendoza, Razin, and Tesar (1994) developed a much simpler method that uses the actual tax revue data at a Macro level. Yet this received as much controversy as the King-Fullerton approach due to the assumptions they made and its too much simplicity that departs from the reality. These two approaches are distinct in the fundamental concepts so called the forward-looking vs. backward-looking approach. The forward-looking approach hypothesizes a certain investment project and a household to calculate the capital, labor, and consumption tax rates that are expected. For this, it hypothesizes the types of assets, the ways of finance, the tax status of the investor and household. The tax rates calculated by King and Fullerton (1984) represent this forward-looking approach. The alternative approach, the backward-looking approach, uses the actual tax revenue collected and compares it with the before-tax incomes and/or expenditures. The method from Mendoza et al. (1994) corresponds to this backward-looking approach, and was used in Rodrik (1997) which analyzed why the distribution of tax shifted from capital to labor. Daveri and Tabellini (2000) also used Mendoza's tax rates and argued that high labor tax rates in European continents led to systematically high unemployment rates. One of the criticisms that Mendoza's tax rates face is that, due to the backward-looking nature, it does not provide a picture of how the concurrent tax system affects the incentives of economic agents' behaviors on investment, labor supply, and consumption ex ante. However, as Sorensen (2004) summarizes, the forward-looking rate and the backward-looking rate become 
identical when an economy grows at the golden rule, and the capital stock grows at a real interest rate being constant over time, and if the rate of depreciation in the tax code is constant over time at the true depreciation rate. Carey and Rabesona (2002) claim several assumptions in Mendoza et al. (1994) to be unrealistic. First, OECD's Revenue Statistics does not define the source of household income as labor income and capital income. Thus, households are assumed to contribute the same tax rate to the capital tax and the labor tax. Second, the self-employed workers' earning is assumed to be all capital income. Third, the deductibility of social security contributions from taxable income is not incorporated. Finally, taxable income includes social security contribution but not private employer's contributions to pension funds in Mendoza's tax rates.

Despite a number of restrictive assumptions, Mendoza et al. (1994) remains as the data that provides extensive countries and periods which are needed for the cross-country time series analysis such as ours. In addition, Daveri and Tabellini (2000) extended the available data to $1995 .^{10}$

\subsection{The theoretical development}

There are two major channels that link economic integration and domestic taxation. First, trade in goods and services indirectly affects the demand elasticity of factors of production such as capital and labor. This change in elasticity alters the optimal tax rate on factor inputs based on the excess burden of taxation. Second, in an open economy, capital and labor can move across national borders. This factor mobility can

\footnotetext{
${ }^{10}$ Enrique Mendoza generously makes the data available on his website. I also thank Francesco Daveri for providing the updated data.
} 
have direct and indirect effect on both tax revenue and tax rates. The inflows of production factors alter the taxable bases that government can impose taxes, and in turn, raise tax revenues ceteris paribus the tax rates. They also directly alter the tax rates as some argue in the framework of a political economy model. Below, we provide the summary of each channel.

Slaughter (2001) provides the summary on how economic integration can make labor demand more elastic. Labor demand elasticity $\left(\eta_{L}\right)$ is the weighted sum of the constant-output elasticity of substitution between labor and other factors $(\sigma)$ and the product demand elasticity $(\eta)$ as Hamermesh (1993) summarizes.

(1) $\quad \eta_{L}=-[1-s] \sigma-s \eta$ where $s$ is the share of labor in income.

$\sigma$ is the indication of how much labor is substituted with other factor inputs holding output constant when the cost of labor becomes more expensive relative to other inputs. Opening trade increases $\sigma$ as firms have more access to foreign factor inputs including labor by shifting production abroad or buying intermediate inputs from abroad. Opening trade also increases the product demand elasticity, $\eta$, as firms face more foreign competition. Both of these contribute to an increase in the labor demand elasticity (Slaughter 2001). The empirical work in Slaughter (2001) provides the evidence that an increase in international trade has made the demand of production labor in manufacture industries more elastic.

In the partial equilibrium model, when either labor demand or labor supply or both become more elastic, the excess burden of labor tax increases. Thus, we may have lower taxes on labor income if in fact the labor market has become more elastic. If 
opening trade increases the labor demand elasticity, as claimed by Slaughter (2001), then, the labor tax rate has to be lowered so as to minimize the excess burden. Furthermore, the tax incidence literature shows that the incidence of the labor tax on the laborer increases if demand for labor becomes more elastic. Thus, the burden of the labor tax as well as other non-labor cost fall more on laborers and less on employers for any given tax rate. Rodrik (1997) pointed out two other impacts of an increase in labor demand elasticity on the labor market. As labor demand becomes more elastic, it takes bargaining power away from laborers. Thus, it becomes easier for employers to pass non-labor costs on to laborers. Also, it makes the labor market more volatile as external shocks that affect labor demand result in a larger change in the wage rate. With consideration to these effects, government may opt to lower labor tax rate.

By combining the trade impact on labor demand elasticity and the excess burden explanation along with its secondary effect noted above, economic integration may lead to a lower labor tax rate in a partial equilibrium framework.

The similar analogy to the above can be applied to taxation on capital. Economic integration may make the capital demand more elastic (Rodrik, 1997). If that is the case, further economic integration leads to the lower optimal capital tax rate.

Likewise, the optimal consumption tax rate is lowered as the demand elasticity in the goods market increases. The trade theory usually assumes that once an economy is opened to the world market, the domestic demand becomes infinitely elastic for firms. This leads to the optimal commodity tax to be zero. This is an extreme circumstance, in reality, since there are a numerous barriers to trade not only through tariffs but also NonTariff Barriers and other barriers related to business customs, language, culture, etc. 
However, still the principle remains that increasing economic integration lowers the optimal consumption tax rate. On the other hand, some literature including Keen and Ligthart (2002), Hatzipanayotou, Michael, and Miller (1994), and Michael, Hatzipanayotou, and Miller (1993) argue that elimination of tariffs combining with increase in consumption tax as to maintain revenue is welfare enhancing for a small open economy. It is left to empirical studies whether economic integration has done any to consumption taxes.

The second channel which economic integration influences domestic taxation is through the changes in the tax base. Economic integration comes with increase in flows of both goods and factor inputs, capital and labor. Net inflows of capital and labor increase the taxable base for governments. Due to the nature of public good in the publicly provided goods and services, labor inflow may not increase the cost of government spending per head linearly, and indeed may very well decrease. ${ }^{11}$ Net inflow of capital expands the taxable base and this allows governments to lower tax rates. Alternatively, factor inflow, particularly labor inflow may alter the political structure as Razin, Sadka, and Swagel (2002) argue, and this may influence domestic taxation. Increase in immigration may lower the share of government spending that is appropriated for the native. Hence, the native voters may vote in favor of lower government spending per head and lower tax rates. Whether inflows of capital and labor have lowered the corresponding tax rates is an empirical question we tackle in this essay.

\footnotetext{
${ }^{11}$ Alternatively, one can assume that government's production function follows an increasing return to scale. Thus, the average cost to provide government services declines.
} 


\subsection{Review of some relevant empirical works}

Rodrik (1997) estimates how openness to trade and exposure to external risk affect capital and labor tax rates. External risk is defined as the income variation due to exchange volatility. He found that openness is associated with a rise in the labor tax rate and a fall in the capital tax rate at statistically significant levels, though when external risk is taken into account, the erosion of the capital tax rate becomes insignificant. He claims that economic integration changes the structure of domestic taxation in the way that the tax burden shifts from capital to labor.

Razin, Sadka, and Swagel (2002) study the effect of migration on the labor tax rate, and found that the larger share of immigrants in a population leads to a lower labor income tax with statistically a significant level. They explained that as the share of immigrants grows, a larger proportion of tax revenue is spent for immigrants. Thus, a median voter, not affected by immigration, tends to vote in favor of lower labor income tax. While trade itself is not a major concern for their paper, it is included in their estimation, and in the most of their specification, it has a negative coefficient though insignificant. This is different from Rodrik (1997).

While the literatures focus either on the capital tax or the labor tax, there is a possibility that the government shifts taxation on to consumption in response to an increase in economic integration with the world economy. Mendoza etc. (1994) noted that the countries with low capital tax rates tend to have high consumption tax rates. The economic integration may lower the capital tax rate, however, the burden of taxation may not shift on to labor but instead shift toward consumption in the pressure to maintain a balanced budget. Therefore, it is important to look at how economic integration 
influences the tax rates of capital and labor as well as consumption. In addition, it is important to include both trade and factor flows in the analysis since both features of economic integration have possible channels to influence domestic tax rates. There has not been such a comprehensive empirical study. This paper pursues to do this.

\section{The data description}

All the data are for OECD countries during the period of 1970 to 1995 . The dependent variables in all estimations are the average effective tax rates on capital, labor, and consumption. Tax rates in the data set are in percentage points. These rates are defined and calculated in Mendoza, Razin, and Tesar (1994). ${ }^{12}$ The countries that are included are Australia, Austria, Belgium, Canada, Denmark, Finland, France, Germany, Italy, Japan, Norway, Spain, Sweden, Switzerland, the United Kingdom, Netherlands, and New Zealand. The explanatory variables include the share of trade volume in GDP, net inflow of Foreign Direct Investment (FDI), the share of foreign population in total population, GDP per capita, general government final consumption expenditure, general government gross financial liability, external risk, standard deviation of exchange risk, the share of labor force in total population, inflation rate, unemployment rate. All exchange rate data is on the base of US dollar. Thus, the U.S. is excluded from the data. The external risk variable is calculated according to Rodrik (1997). It is the standard deviation of the change in logarithm of the monthly spot rate multiplied by the share of

\footnotetext{
12 The updated version of the tax data is kindly made available on the web by Mendoza (http://www.bsos.umd.edu/econ/mendoza/). I also thank Francesco Daveri for providing me the extended periods of the tax rates data used in Daveri and Tabellini (2000).
} 
trade. ${ }^{13}$ It measures unanticipated income effects due to the exchange rate. The government liability data is taken from OECD economic outlook. The exchange rate data are obtained from Thomson Datastream. All other data are from World Development Indicators. The missing data are excluded, thus, the data set is an unbalanced panel data. The number of observation available varies for each regression, mostly contingent on the tax rate availability.

Table 1 provides the description of the variables, and Table 2 shows the summary statistics of the tax rates for each country.

\section{Specification and Estimation Strategy}

We estimate the tax rates on capital, labor, and consumption separately. The explanatory variables are common to all regressions. The key explanatory variables that we are interested in are trade of goods and services, net FDI inflow, and foreign population. The basic specification is:

$$
\operatorname{Tax}_{k i t}=\alpha+\beta X_{i t}+\gamma Z_{i t}+\varepsilon_{k i t}
$$

where $k$ is each type of tax, $i$ is each country, and $t$ is each year. $X$ contains trade, FDI, and foreign population. $Z$ contains other control variables such as GDP per capita, government consumption, government debt, exchange rate volatility, inflation rate, and unemployment rate, and total population.

First, we estimate (2) using a fixed effects model assuming that unobserved shocks on the effective tax rates are uncorrelated with the explanatory variables and that

\footnotetext{
${ }^{13}$ For the spot rate data, I thank Hannah Francis at Thomson Datastream.
} 
they do not affect the tax rates in the following period. In other words, we assume there is no endogeneity problem and serial correlation. While these may be restrictive assumptions, they are simple and play a role as a first pass. Next, we pay some caution to a possible serial correlation in the error term in (2). Suppose the error term takes form as

$$
\varepsilon_{k i t}=\rho \varepsilon_{k i t-1}+u_{k i t}
$$

where $u_{\text {kit }}$ is white noise, and $\rho$ is significant. One possibility of the presence of serial correlation is that the equation (2) is miss-specified for omitting the lagged tax rate in the regressants. As Mendoza et al. (1994) shows, the trends of tax rates have some persistency over the period. Thus, capturing such a dynamic aspect may be more appropriate specification. We add the lagged tax rate in the equation (2) and estimate the following.

$$
\operatorname{Tax}_{k i t}=\alpha+\beta X_{i t}+\gamma Z_{i t}+\delta \operatorname{Tax}_{k i t-1}+\varepsilon_{k i t}
$$

The possible presence of serial correlation is also a problem especially when we suspect $X_{i t}$ is endogenous and correlated with the error term because this gives biased estimates.

If the specification (4) is not suffered from serial correlation, then, the potential endogeneity problem can be solved by the instrumental variable estimation with the instrument being:

$$
X_{i t}=a+b X_{i t-1}+e_{i t}
$$

If not, alternative estimation methods should be used such as the Seemingly Unrelated Regression method or Full Information Maximum Likelihood Estimation method. Another alternative specification that is developed by Arellano and Bond (1991) is also 
an option. In this case, it is assumed that the error term includes the individual specific term, which can be a cause of serial correlation.

$$
\operatorname{Tax}_{i, t}=\delta \operatorname{Tax}_{i, t-1}+\beta X_{i, t}+\gamma Z_{i, t}+v_{i}+u_{i, t}
$$

Again because of serial correlation and the endogeneity problem in $X_{i t}$, we can not use a simple instrumental variable method with (5). Using the fixed or random effect estimation of (6) leads to biased estimates. ${ }^{14}$ Among others, Arellano and Bond (1991) developed a consistent and efficient estimation method, which uses a generalized method of moment (GMM) procedure with instruments. The basic estimation model takes first difference so as to remove the individual effect in (6).

$$
\Delta \operatorname{Tax}_{i, t}=\delta \Delta \operatorname{Tax}_{i, t-1}+\beta \Delta X_{i, t}+\gamma \Delta Z_{i t}+\Delta u_{i, t}
$$

where $\Delta$ is the first difference operator. As the error term in (7) is still correlated with $\Delta \operatorname{Tax}_{i, t-1}$, instrumental variable technique is needed. Arellano and Bond (1991) argue that a dependent variable lagged two periods back and more can be used as instrumental variables in addition to exogenous variables $(Z)$ to obtain unbiased $\beta$.

\section{Results}

Table 3 shows the fixed effects estimates of the equation (2). Rodrik (1997) and European Commission (1997) made the argument previously that the increasing pressure of economic integration has shifted the tax burden from capital to labor. However, as discussed in the previous section, the feature of economic integration, flows of goods and

\footnotetext{
${ }^{14}$ See Baltagi (2001) p130, Nickell (1981), Kiviet (1995)
} 
factor inputs, can theoretically lower the all corresponding tax rates. However, the result shows that trade is not associated with the capital tax rate or the labor tax rate at statistically significant levels. The factor flows, both capital and labor, are also insignificant in both the capital and labor tax equations. Moreover, the estimates do not show that the government shifts tax burden away from capital and into labor as Rodrik (1997) claimed. The only factor that reduces the capital tax, yet increases the labor tax rate is labor inflow measured in the share of foreign labor, though it is statistically insignificant. The consumption tax rate turns out to be the one most affected by economic integration. Trade volume, net inflow of FDI and the share of foreign population are all negatively associated with the consumption tax at statistically significant level. Especially the impact of foreign population is large. A 1 percent increase in the share leads to a near 0.9 percent reduction of the consumption tax rate. The channel at which capital and labor inflow reduce the consumption tax rate had not been explored deeply in the literature yet. Kanbur and Keen (1993), in their cross-border shopping competition model, claimed that a larger population leads to a higher consumption tax. Razin, Sadka, and Swagel (2002) found that an increase in foreign population leads to a lower labor tax, rather than a consumption tax, using the political economy model. We find no support on these claims. Rather, we believe, our results show the increasing pressure of economic integration lowers the optimal tax rates on capital, labor, and consumption. At the same time, the countries receiving the factor inputs from abroad were able to lower the tax rates.

Besides these three factors, the estimated coefficient of government liability is always significant and positive in all tax equations. This shows regardless of the size of 
government, how its spending is financed matters in determining the effective tax rates.

The failure to balance budgets by governments seems to ultimately raise the effective tax rates. The total population, the measure for the size of country used in the literature, has insignificant coefficients in the all tax equations. The unemployment rate is positively associated with the labor tax rate, but negatively associated with the capital tax rate. Higher unemployment rates lead to a higher labor tax rate, that is, laborers bear the burden by themselves. On the other hand, the owners of capital seem to have an ease of the tax burden during recessions when unemployment is high. The inflation rate is positive and significant in all three tax rates. One possibility of this is that inflation pushes the tax bracket of tax payers up raising the effective average tax rates. For capital and labor tax rates, the different rates among the countries are explained by government liability, government consumption, the inflation rate, and the unemployment rate rather than the flows of goods and services and production factors. For the consumption tax rate, the difference in the flows of goods and factor inputs among the countries, in addition to government debt, government consumption and the inflation rate, explains the difference in the average consumption tax rate.

With the concern of serial correlation, we estimated the autoregressive error term and turned out to be $0.73,0.37$, and 0.46 for the capital, labor, and the consumption tax equations respectively. These rather high values of the first order autocorrelation of the errors cast doubts that the lagged tax rates should be included in the regressants as in the equation (4). We provide the estimates of the equation (4) in the Table 4. The lagged tax rates are significant in all tax equations. The values are also significantly high ranging from 0.43 to 0.60 showing the strong dynamic persistent patterns of the tax rates. The 
coefficients of interest, trade, net inflow of FDI, and the share of foreign labor, did not show drastic qualitative change from the previous estimations. Particularly, these coefficient estimates remain statistically significant in the consumption tax equation with all negative signs. The variables that explain the differences of the tax rates among the countries also are the same as in the previous model, and include government consumption, government liability, the inflation rate, the unemployment rate for the capital and labor taxes, and for the consumption tax, trade and factor flows are also included. The estimates of the first order autocorrelation diminish to $0.30,-0.06$, and 0.10 for the capital, labor and consumption tax equations respectively. With the statistically significant coefficient estimates of the lagged tax rates, the inclusions of the lagged tax rates appear more appropriate. Concerning the endogeneity problem of trade and factor flows in the equation, finding small autocorrelation of the error terms allow us to use the lagged endogenous variables as instrumental variables. We provide the results in the Table 5. The qualitative implications of trade and factor flows for the tax rates stay the same though, the significance of the coefficient estimates go away in the consumption tax equation.

The other method, the Arellano-Bond estimate, utilizes more instrumental variables by including more than one lag. The estimates are reported in the table 6 . The lagged tax rates on capital, labor, and consumption have all significant coefficients and are positive as in the previous models. The estimate for the lagged capital tax rate is 0.57 , higher than those of labor and consumption with 0.46 and 0.44 respectively. Thus, the capital tax rate seems to have a more persistent trend than the other two. Coefficients in this model provide the impact of newly added information. The estimated coefficients for 
trade and factor flows are all insignificant in the capital and labor tax equations. Trade and FDI are significant in the consumption equation, but foreign population is insignificant while the signs are all negative as in the previous estimates.

All estimation models consistently show that trade and factor flows do not influence the effective tax rate on capital and labor at statistically significant levels. The coefficients of trade are mostly negative in all tax equations. This may indicate undermining government's ability to levy taxes. However, we fail to provide the evidence of this in a statistically significant manner. The coefficients of trade and factor flows are, on the other hand, always negative, and mostly statistically significant. Therefore, the claim that increasing economic integration undermines domestic taxation may be applied correctly for consumption, but not for the taxation on production factors.

\section{Conclusion}

In this study, we attempted to explain the different level and trend of tax rates among industrial countries by looking at their paths toward economic integration. The industrial countries, while they are all integrated with the world economy more or less, differ in the magnitude of their integration. Some countries are more dependent on trade in accruing incomes, absorbing the world capital, and opt to accept foreign labor while others are more regulatory and less connected with the outside economies. At the same time, these countries have exhibited different pattern of tax rates on capital, labor, and consumption. The trends of these tax rates also differ among the countries. 
The previous literature claimed these two, domestic taxation and economic integration, are linked. International trade is said to decrease the capital tax rate and increase the labor tax rate. Our study did not confirm the linkage between capital and labor tax rates and such features of economic integration. The difference in trade volume and flows of capital and labor across countries seems to be unable to explain the differences in the capital and labor tax rates across countries. Interestingly, the strong relation between economic integration and domestic taxation was found in the consumption tax rate. The previous empirical studies have missed this point. Actual linkage between the consumption tax and economic integration may be more complex than described here. Since governments can choose different sources to levy taxes, the pressures of economic integration put on the labor and capital market do not need to be realized in the taxations of the corresponding earnings. We believe that the wave of globalization and the benefits of labor and capital flows have fallen on the good market in the form of a lower consumption tax. 
Table 1 Description of the variables.

\begin{tabular}{ll}
\hline Variable & Description \\
\hline captax & the effective average capital tax rate \\
labtax & the effective average labor tax rate \\
contax & the effective average consumption tax rate \\
tradegdp & the share of trade volume in GDP \\
nfdigdp & the net inflow of foreign direct investment as a share of GDP \\
fpop & the share of foreign population in the total population \\
tpopm & total population in million \\
gdppck & GDP per capita in thousand dollars \\
govcons & General government final consumption expenditure as a share of \\
govliabil & GDP \\
extrisk & general government gross financial liability as a share of GDP \\
the external risk defined as the standard deviation of the change in \\
inflation & the logarithm of monthly spot rate multiplied by the share of trade \\
unemploy & inflation rate \\
\hline
\end{tabular}

Note: the tax rates are defined in Mendoza et al. (1994) 
Table 2 Summary Statistics of tax rates: Mean and Standard deviation over the period

\begin{tabular}{lrrr}
\hline country & captax & labtax & \multicolumn{1}{c}{ contax } \\
\hline Australia & 41.046 & 16.332 & 8.278 \\
& $(6.233)$ & $(3.176)$ & $(0.910)$ \\
Austria & 21.132 & 37.411 & 20.616 \\
& $(2.045)$ & $(3.403)$ & $(1.227)$ \\
Belgium & 34.959 & 42.759 & 17.239 \\
& $(5.116)$ & $(5.731)$ & $(0.957)$ \\
Canada & 42.651 & 24.510 & 12.168 \\
& $(5.011)$ & $(5.192)$ & $(1.167)$ \\
Switzerland & 23.718 & 28.366 & 7.357 \\
& $(4.961)$ & $(5.443)$ & $(0.676)$ \\
Germany & 26.564 & 37.713 & 15.945 \\
& $(3.669)$ & $(4.456)$ & $(1.124)$ \\
Denmark & 34.307 & 42.602 & 34.467 \\
& $(3.085)$ & $(2.454)$ & $(1.825)$ \\
Spain & 15.509 & 30.248 & 10.080 \\
& $(4.747)$ & $(6.723)$ & $(2.836)$ \\
Finland & 34.557 & 30.826 & 25.263 \\
& $(8.804)$ & $(7.443)$ & $(3.834)$ \\
France & 23.989 & 40.689 & 20.011 \\
& $(3.839)$ & $(7.835)$ & $(2.559)$ \\
UK & 54.713 & 25.114 & 15.009 \\
Italy & $(9.472)$ & $(2.036)$ & $(2.051)$ \\
& 26.667 & 39.249 & 13.023 \\
Japan & $(7.410)$ & $(6.658)$ & $(1.694)$ \\
& 35.243 & 22.371 & 5.334 \\
Netherlands & $(9.871)$ & $(4.735)$ & $(0.550)$ \\
Norway & 30.183 & 49.329 & 17.508 \\
New Zealand & $(3.553)$ & $(5.879)$ & $(0.802)$ \\
Sweden & 36.212 & 38.244 & 33.149 \\
& $(6.849)$ & $(2.845)$ & $(4.295)$ \\
& 35.896 & 25.910 & 11.837 \\
Note: Stand & $(3.308)$ & $(1.130)$ & $(4.076)$ \\
& 50.397 & 46.083 & 21.549 \\
& $(10.174)$ & $(5.701)$ & $(2.527)$ \\
\hline & & \\
& & & \\
& & &
\end{tabular}

Note: Standard deviations in parentheses. 
Table 3 Fixed Effect Estimations

\begin{tabular}{|c|c|c|c|}
\hline & $\begin{array}{l}\text { (1) } \\
\text { mcaptax }\end{array}$ & $\begin{array}{l}(2) \\
\text { mlabtax }\end{array}$ & $\begin{array}{l}(3) \\
\text { mcontax }\end{array}$ \\
\hline tradegdp & $\begin{array}{l}-\mathbf{- 0 . 1 6 1} \\
(1.18)\end{array}$ & $\begin{array}{l}\mathbf{- 0 . 0 8 8} \\
(1.57)\end{array}$ & $\begin{array}{l}\mathbf{- 0 . 1 2 1} \\
(3.29)^{* * *}\end{array}$ \\
\hline nfdigdp & $\begin{array}{l}\mathbf{0 . 3 4 2} \\
(0.48)\end{array}$ & $\begin{array}{l}\mathbf{0 . 0 6 0} \\
(0.21)\end{array}$ & $\begin{array}{l}-\mathbf{0 . 6 0 6} \\
(2.68)^{* * *}\end{array}$ \\
\hline fроp & $\begin{array}{l}\mathbf{- 1 . 1 4 0} \\
(1.15) \\
\end{array}$ & $\begin{array}{l}\mathbf{0 . 1 0 7} \\
(0.26) \\
\end{array}$ & $\begin{array}{l}\mathbf{- 0 . 8 8 5} \\
(2.56)^{* *}\end{array}$ \\
\hline gdppck & $\begin{array}{l}-0.496 \\
(1.14)\end{array}$ & $\begin{array}{l}0.227 \\
(1.28)\end{array}$ & $\begin{array}{l}0.069 \\
(0.45)\end{array}$ \\
\hline govcons & $\begin{array}{l}1.059 \\
(1.49)\end{array}$ & $\begin{array}{l}-0.829 \\
(2.86) * * *\end{array}$ & $\begin{array}{l}-0.457 \\
(2.19)^{* *}\end{array}$ \\
\hline govliabil & $\begin{array}{l}0.251 \\
(4.64)^{* * *}\end{array}$ & $\begin{array}{l}0.142 \\
(6.42)^{* * *}\end{array}$ & $\begin{array}{l}0.093 \\
(5.20)^{* * *}\end{array}$ \\
\hline extrisk & $\begin{array}{l}-0.867 \\
(0.88)\end{array}$ & $\begin{array}{l}0.383 \\
(0.96)\end{array}$ & $\begin{array}{l}0.066 \\
(0.22)\end{array}$ \\
\hline stdexch & $\begin{array}{l}143.195 \\
(1.74)^{*}\end{array}$ & $\begin{array}{l}-37.715 \\
(1.12)\end{array}$ & $\begin{array}{l}-4.560 \\
(0.20)\end{array}$ \\
\hline tpopm & $\begin{array}{l}-0.719 \\
(0.65)\end{array}$ & $\begin{array}{l}-0.405 \\
(0.90)\end{array}$ & $\begin{array}{l}0.025 \\
(0.07)\end{array}$ \\
\hline inflation & $\begin{array}{l}1.139 \\
(3.75)^{* * *}\end{array}$ & $\begin{array}{l}0.320 \\
(2.58)^{* *}\end{array}$ & $\begin{array}{l}0.284 \\
(2.81)^{* * *}\end{array}$ \\
\hline unemploy & $\begin{array}{l}-0.735 \\
(2.08)^{* *}\end{array}$ & $\begin{array}{l}0.908 \\
(6.28) * * *\end{array}$ & $\begin{array}{l}-0.068 \\
(0.46)\end{array}$ \\
\hline Constant & $\begin{array}{l}52.332 \\
(1.43)\end{array}$ & $\begin{array}{l}52.362 \\
(3.50)^{* * * *}\end{array}$ & $\begin{array}{l}30.554 \\
(2.34)^{* *}\end{array}$ \\
\hline Observations & 113 & 113 & 89 \\
\hline $\begin{array}{l}\text { Number of } \\
\text { country }\end{array}$ & 15 & 15 & 13 \\
\hline Adj R-squrd & 0.26 & 0.59 & 0.30 \\
\hline $\mathrm{AR}(1)$ error & 0.73 & 0.37 & 0.46 \\
\hline
\end{tabular}

Notes:

Absolute value of $\mathrm{t}$ statistics in parentheses

$*$ significant at $10 \% ; * *$ significant at $5 \% ; * * *$ significant at $1 \%$ 
Table 4 Fixed effects with lagged tax rates

\begin{tabular}{|c|c|c|c|}
\hline & $\begin{array}{l}\text { (1) } \\
\text { mcaptax }\end{array}$ & $\begin{array}{l}(2) \\
\text { mlabtax }\end{array}$ & $\begin{array}{l}(3) \\
\text { mcontax }\end{array}$ \\
\hline tradegdp & $\begin{array}{l}\mathbf{- 0 . 0 4 9} \\
(0.44)\end{array}$ & $\begin{array}{l}\mathbf{- 0 . 0 5 2} \\
(1.05)\end{array}$ & $\begin{array}{l}\mathbf{- 0 . 0 9 1} \\
(2.71)^{* * *}\end{array}$ \\
\hline nfdigdp & $\begin{array}{l}\mathbf{0 . 3 3 2} \\
(0.58)\end{array}$ & $\begin{array}{l}\mathbf{- 0 . 0 8 8} \\
(0.35)\end{array}$ & $\begin{array}{l}-\mathbf{0 . 5 8 5} \\
(2.91)^{* * *}\end{array}$ \\
\hline fpop & $\begin{array}{l}-\mathbf{- 0 . 7 2 5} \\
(0.92) \\
\end{array}$ & $\begin{array}{l}\mathbf{0 . 1 7 4} \\
(0.50) \\
\end{array}$ & $\begin{array}{l}-\mathbf{0 . 6 6 7} \\
(2.14)^{* *}\end{array}$ \\
\hline gdppck & $\begin{array}{l}-0.152 \\
(0.44)\end{array}$ & $\begin{array}{l}0.055 \\
(0.35)\end{array}$ & $\begin{array}{l}0.074 \\
(0.55)\end{array}$ \\
\hline govcons & $\begin{array}{l}0.298 \\
(0.52)\end{array}$ & $\begin{array}{l}-0.536 \\
(2.11)^{* *}\end{array}$ & $\begin{array}{l}-0.551 \\
(2.95)^{* * *}\end{array}$ \\
\hline govliabil & $\begin{array}{l}0.103 \\
(2.17)^{* *}\end{array}$ & $\begin{array}{l}0.084 \\
(3.95)^{* * *}\end{array}$ & $\begin{array}{l}0.055 \\
(3.05)^{* * *}\end{array}$ \\
\hline extrisk & $\begin{array}{l}-0.908 \\
(1.14)\end{array}$ & $\begin{array}{l}0.246 \\
(0.69)\end{array}$ & $\begin{array}{l}-0.098 \\
(0.37)\end{array}$ \\
\hline stdexch & $\begin{array}{l}124.974 \\
(1.89)^{*}\end{array}$ & $\begin{array}{l}-21.615 \\
(0.73)\end{array}$ & $\begin{array}{l}9.324 \\
(0.45)\end{array}$ \\
\hline tpopm & $\begin{array}{l}-0.661 \\
(0.76)\end{array}$ & $\begin{array}{l}-0.155 \\
(0.40)\end{array}$ & $\begin{array}{l}-0.043 \\
(0.13)\end{array}$ \\
\hline inflation & $\begin{array}{l}0.149 \\
(0.54)\end{array}$ & $\begin{array}{l}0.275 \\
(2.56)^{* *}\end{array}$ & $\begin{array}{l}0.186 \\
(2.01)^{* *}\end{array}$ \\
\hline unemploy & $\begin{array}{l}-0.749 \\
(2.68)^{* * *}\end{array}$ & $\begin{array}{l}0.661 \\
(4.98)^{* * *}\end{array}$ & $\begin{array}{l}0.011 \\
(0.08)\end{array}$ \\
\hline mcaptax 1 & $\begin{array}{l}0.605 \\
(7.52)^{* * *}\end{array}$ & & \\
\hline mlabtax 1 & & $\begin{array}{l}0.461 \\
(5.70)^{* * *}\end{array}$ & \\
\hline $\operatorname{mcontax} 1$ & & & $\begin{array}{l}0.431 \\
(4.28)^{* * *}\end{array}$ \\
\hline Constant & $\begin{array}{l}39.167 \\
(1.35)\end{array}$ & $\begin{array}{l}27.240 \\
(2.01)^{* *}\end{array}$ & $\begin{array}{l}26.302 \\
(2.26)^{* *}\end{array}$ \\
\hline Observations & 112 & 112 & 89 \\
\hline $\begin{array}{l}\text { Number of } \\
\text { country }\end{array}$ & 15 & 15 & 13 \\
\hline Adj R-squrd & 0.55 & 0.70 & 0.45 \\
\hline $\mathrm{AR}(1)$ error term & 0.30 & -0.06 & 0.10 \\
\hline
\end{tabular}

Notes:

Absolute value of $t$ statistics in parentheses

$*$ significant at $10 \% ; * *$ significant at $5 \% ; * * *$ significant at $1 \%$ 
Table 5 Instrumental Variable Estimation

\begin{tabular}{|c|c|c|c|}
\hline & $\begin{array}{l}(1) \\
\text { mcaptax }\end{array}$ & $\begin{array}{l}(2) \\
\text { mlabtax }\end{array}$ & $\begin{array}{l}\text { (3) } \\
\text { mcontax }\end{array}$ \\
\hline \multirow[t]{2}{*}{ tradegdp } & 1.014 & -0.199 & -0.042 \\
\hline & $(1.47)$ & $(1.06)$ & $(0.38)$ \\
\hline \multirow[t]{2}{*}{ nfdigdp } & -0.135 & 0.357 & -1.686 \\
\hline & $(0.04)$ & $(0.34)$ & $(1.13)$ \\
\hline \multirow[t]{2}{*}{ fpop } & -2.402 & 0.710 & -0.634 \\
\hline & $(1.49)$ & $(1.35)$ & $(0.76)$ \\
\hline \multirow[t]{2}{*}{ gdppck } & 0.444 & -0.139 & 0.190 \\
\hline & $(0.62)$ & $(0.59)$ & $(0.98)$ \\
\hline \multirow[t]{2}{*}{ govcons } & 2.788 & -0.910 & -0.428 \\
\hline & $(1.52)$ & (1.59) & $(1.15)$ \\
\hline \multirow[t]{2}{*}{ govliabil } & -0.040 & 0.096 & 0.046 \\
\hline & $(0.33)$ & $(3.06) * * *$ & $(1.80)^{*}$ \\
\hline \multirow[t]{2}{*}{ extrisk } & -3.929 & 0.675 & -0.459 \\
\hline & $(1.78)^{*}$ & (1.04) & $(1.01)$ \\
\hline \multirow[t]{2}{*}{ stdexch } & 312.937 & -45.523 & 22.706 \\
\hline & $(1.96)^{*}$ & $(0.95)$ & $(0.68)$ \\
\hline \multirow[t]{2}{*}{ tpopm } & -0.782 & 0.089 & -0.290 \\
\hline & $(0.45)$ & $(0.16)$ & $(0.68)$ \\
\hline \multirow[t]{2}{*}{ inflation } & -0.457 & 0.286 & 0.233 \\
\hline & $(0.62)$ & $(1.68)^{*}$ & $(1.32)$ \\
\hline \multirow[t]{2}{*}{ unemploy } & -1.827 & 0.766 & -0.104 \\
\hline & $(1.93)^{*}$ & $(2.79) * * *$ & $(0.55)$ \\
\hline \multirow[t]{2}{*}{ mcaptax 1} & 0.750 & & \\
\hline & $(4.65)^{* * *}$ & & \\
\hline mlabtax 1 & & $\begin{array}{l}0.452 \\
(5.10) * * *\end{array}$ & \\
\hline $\operatorname{mcontax} 1$ & & & 0.443 \\
\hline \multirow[t]{2}{*}{ Constant } & 35.532 & 46.779 & 35.283 \\
\hline & $(0.17)$ & $(1.51)$ & $(0.75)$ \\
\hline Observations & 108 & 108 & 85 \\
\hline Adj R-squrd & 0.80 & 0.98 & 0.99 \\
\hline
\end{tabular}

Absolute value of $t$ statistics in parentheses

$*$ significant at $10 \% ; * *$ significant at $5 \% ; * * *$ significant at $1 \%$ 
Table 6 Arellano-Bond dynamic panel data estimates

\begin{tabular}{|c|c|c|c|}
\hline & $\begin{array}{l}\text { (1) } \\
\text { D.mcaptax }\end{array}$ & $\begin{array}{l}\text { (2) } \\
\text { D.mlabtax }\end{array}$ & $\begin{array}{l}\text { (3) } \\
\text { D.mcontax }\end{array}$ \\
\hline D.tradegdp & $\begin{array}{l}-\mathbf{- 0 . 0 2 5} \\
(0.23)\end{array}$ & $\begin{array}{l}\mathbf{- 0 . 0 5 7} \\
(1.07)\end{array}$ & $\begin{array}{l}\mathbf{- 0 . 0 9 1} \\
(2.57)^{* *}\end{array}$ \\
\hline D.nfdigdp & $\begin{array}{l}\mathbf{0 . 3 4 0} \\
(0.64)\end{array}$ & $\begin{array}{l}-\mathbf{0 . 0 9 0} \\
(0.34)\end{array}$ & $\begin{array}{l}\mathbf{- 0 . 5 9 1} \\
(2.95)^{* * *}\end{array}$ \\
\hline D.fpop & $\begin{array}{l}\mathbf{0 . 1 7 5} \\
(0.21)\end{array}$ & $\begin{array}{l}\mathbf{0 . 0 4 2} \\
(0.10)\end{array}$ & $\begin{array}{l}-\mathbf{0 . 5 1 5} \\
(1.36)\end{array}$ \\
\hline D.tpopm & $\begin{array}{l}-0.650 \\
(0.78)\end{array}$ & $\begin{array}{l}-0.157 \\
(0.37)\end{array}$ & $\begin{array}{l}-0.061 \\
(0.18)\end{array}$ \\
\hline D.gdppck & $\begin{array}{l}0.576 \\
(1.40)\end{array}$ & $\begin{array}{l}-0.052 \\
(0.25)\end{array}$ & $\begin{array}{l}0.186 \\
(1.21)\end{array}$ \\
\hline D.govcons & $\begin{array}{l}0.704 \\
(1.28)\end{array}$ & $\begin{array}{l}-0.580 \\
(2.16)^{* *}\end{array}$ & $\begin{array}{l}-0.460 \\
(2.37)^{* *}\end{array}$ \\
\hline D.govliabil & $\begin{array}{l}0.191 \\
(3.52)^{* * *}\end{array}$ & $\begin{array}{l}0.074 \\
(2.94)^{* * *}\end{array}$ & $\begin{array}{l}0.062 \\
(3.37)^{* * *}\end{array}$ \\
\hline D.extrisk & $\begin{array}{l}-1.158 \\
(1.54)\end{array}$ & $\begin{array}{l}0.281 \\
(0.75)\end{array}$ & $\begin{array}{l}-0.050 \\
(0.19)\end{array}$ \\
\hline D.stdexch & $\begin{array}{l}134.703 \\
(2.16)^{* *}\end{array}$ & $\begin{array}{l}-22.679 \\
(0.72)\end{array}$ & $\begin{array}{l}3.485 \\
(0.17)\end{array}$ \\
\hline D.inflation & $\begin{array}{l}0.052 \\
(0.19)\end{array}$ & $\begin{array}{l}0.303 \\
(2.49) * *\end{array}$ & $\begin{array}{l}0.146 \\
(1.37)\end{array}$ \\
\hline D.unemploy & $\begin{array}{l}-0.858 \\
(3.24)^{* * *}\end{array}$ & $\begin{array}{l}0.675 \\
(4.80) * * *\end{array}$ & $\begin{array}{l}-0.042 \\
(0.29)\end{array}$ \\
\hline LD.mcaptax & $\begin{array}{l}0.539 \\
(6.72)^{* * *}\end{array}$ & & \\
\hline LD.mlabtax & & $\begin{array}{l}0.463 \\
(5.54)^{* * *}\end{array}$ & \\
\hline LD.mcontax & & & $\begin{array}{l}0.437 \\
(4.38)^{* * *}\end{array}$ \\
\hline Constant & $\begin{array}{l}-0.758 * * * \\
(2.82)\end{array}$ & $\begin{array}{l}0.106 \\
(0.82)\end{array}$ & $\begin{array}{l}-0.117 \\
(1.14)\end{array}$ \\
\hline Observations & 96 & 96 & 75 \\
\hline Number of country & 11 & 11 & 11 \\
\hline
\end{tabular}

Notes: refer the equation (7).

D. denotes the first difference

LD. denotes the lagged first difference

Absolute value of $\mathrm{z}$ statistics in parentheses

$*$ significant at $10 \% ; * *$ significant at $5 \% ; * * *$ significant at $1 \%$ 


\section{Chapter 4}

\section{The Search of Heterogeneous Impacts of Trade Barriers across Regions in the U.S.}

\section{Introduction}

In the traditional trade theory, an economy is assumed to be integrated throughout regions. This means that the same technology is available throughout regions; capital is freely mobile within a country; and workers across skills can move between regions at a sufficiently low cost in a short period of time. Therefore, there is a unique factor abundance and relative factor price within a country. If one region observes higher or lower relative factor price than other regions, it ought to be temporary while factor reallocation takes place. International trade occurs due to differences in technology and factor abundance between countries.

A few studies have focused heterogeneous factor distribution within a country and its relationship with international trade. Courant and Deardorff (1992) describe uneven distribution of production factors as "lumpiness", and showed that trade pattern of lumpy country deviates from the traditional trade theory. There hasn't been any empirical scrutiny on lumpiness until recently. Bernard, Jensen, and Schott (2001) provided the evidence of the lumpiness in the case of the United States by showing relative factor price is significantly different across regions. Bernard, Redding, Schott, and Simpson (2002) found the evidence of the lumpiness in the case of the United Kingdom. Most recently, Bernard, Robertson, and Schott (2004) found lumpiness in Mexico. If, in fact, factor abundance is sufficiently different across regions within a country, the bundle of 
goods with comparative advantage is not same across regions. Therefore, the change in tariff and other trade barriers should have different impacts between regions.

Alternatively, Melvin (1985) considers the case where large inter-regional transportation cost deters regional trade and replaces with international trade. In this case, even if regional factor allocation is not lumpy, regions will have different bundles of goods with comparative advantage unless factor allocations are the exactly same across the regions. Then again, there will be differential regional impacts of trade barriers.

Thus, in this paper, we investigate whether tariffs and non-tariff barriers have affected wages of the regions differently for the case of the United States. Based on the F-test where the null hypothesis is that tariffs and non-tariff barriers, both jointly, have no regional impact on wages, we reject the null and find there are heterogeneous regional impacts of trade barriers on wages. We also conduct the F-test for each tariffs and nontariff barriers separately of which the null is that each has homogeneous impact on wages across the regions. The separate test seems to make sense since the measurements of tariffs and non-tariff barriers we used are different. Particularly, we use the coverage ratio as the proxy for non-tariff barrier. Unlike the tariff measure, it does not reveal the magnitude of the trade barrier in terms of its effect on domestic price. Once again, we find that tariffs and non-tariff barriers have regional impacts that are different across the regions. However, when we look into each region's coefficient estimate of the impact of trade barriers on wages, the picture seems puzzling. We find very few regions, if in fact there are, had heterogeneous regional impacts of trade barriers. The number of regions with distinct trade effects was about 5 percent (with statistical significance level of 5 percent) of the Metropolitan Statistical Area that are examined for tariffs and Non-Tariff 
Barriers together (10 percent of the regions with 10 percent statistical significance level). Therefore, we conclude that while there may be some degree of heterogeneous regional effects of trade barriers, the evidence is rather weak. In terms of the impacts of trade barriers, we may go further to say that the labor markets in the U.S. are highly, if not completely, integrated.

This is the first attempt in literature to empirically examine regional impacts of trade barriers on wages, and we urge others to take a closer look at the issue. If in fact, the heterogeneous regional impacts exist, in assessing the welfare effect of trade policies, one should take into consideration the regional redistribution of real income for each factor along with the redistribution among the factors. While we provide the two potential reasons why trade barriers may have regional impacts, we do not test the cause(s) of this, i.e. whether it is due lumpiness or transportation cost. We provide the discussions on the cause(s) based on our results. However, we leave more rigorous investigation in identifying the cause(s) of differential regional impact of trade barriers for future.

The rest of the paper is constructed as follows. Section 2 provides the literature review primarily on the theoretical development of regional analysis of international trade. Section 3 describes the data and estimation model we employ, following the results and discussion in Section 4. Section 5 concludes.

\section{Literature review}

The traditional international trade theory abstracts from differences in consumers' income and taste, and access to technology and resources across regions within a country. Therefore, a country is assumed to have uniform distribution of factor endowments and 
identical factor prices as all regions specialize in production of the same set of goods and services. It is the differences among countries in factor endowment and technology that create international trade. Therefore, the regional implications of international trade and trade policy have been ignored in such a framework. A few studies have broken the conventional assumptions and provided the analysis of regional effects of international trade. Courant and Deardorff (1992) consider the case where production factors are unevenly distributed across regions. Melvin (1985) analyzes the case where transportation cost is high enough to deter regional trade of goods and services. In both scenarios, trade has distinct implications across regions within a country. Trade policy can create winners in one region and losers in another region even for the owner of the same factor. In the following, we provide brief summary and implication of each theory.

Courant and Deardorff (1992) identify an alternative determinant of international trade that is intranatioinal difference in factor endowment. They develop the theory in which uneven distribution of factor endowments leads to international trade in the two good, two factor, and two region framework. The uneven distribution of factors is dubbed as "lumpiness" and can be described in the following Edgeworth Box diagram with two regions $\mathrm{A}$ and $\mathrm{B}$ and two factors, capital and labor. $t_{x}$ and $t_{y}$ are the factor intensities that correspond to the least cost production techniques for good X and $\mathrm{Y}$ respectively given their world prices. $\mathrm{X}$ is assumed to be labor intensive while $\mathrm{Y}$ capital intensive. Within the parallelogram $O_{A} M O_{B} N$, both regions produce both goods $\mathrm{X}$ and $\mathrm{Y}$, thus it is the area of incomplete specialization. The area is called Factor Price Equalization (FPE) parallelogram as factor prices are equalized between two regions within the area regardless of the sizes and the factor abundances of the regions. The shape of FPE 
parallelogram is contingent to consumers' taste and income, production technology, and the world prices of traded goods.

\section{[Graph 1]}

In the area I and II, labor is unevenly distributed to region A while region B has disproportional labor endowment in the area V and VI. Thus, labor is a lumpy factor. Similarly, in the area III, IV, VI, and VII, lumpy factor is capital. When factor allocation is in the area I, region A completely specializes in producing good $\mathrm{Y}$, while region $\mathrm{B}$ produces both goods. As region B is endowed with disproportional amount of labor, the country as a whole produces disproportionately more good $\mathrm{X}$ than people consume, hence, exports good $\mathrm{X}$ and imports good $\mathrm{Y}$. In this manner, Courant and Deardorff (1992) showed that the country exports good X when the factor allocation is in the area I, II, V, and VI while it exports good Y in the area III, IV, VII, and VI. As they put it, "the country tends to export the good that uses relatively intensively the factor that is more unevenly distributed across regions."

We should also note that in the area I and $\mathrm{V}$, one region specializes in good $\mathrm{X}$ while the other region produces both good. In the area IV and VII, one region produces only good $\mathrm{Y}$ while the other region produces both good. On the other hand, in the area II, III, VI, each region specializes in only one good. For instance, in the area II, region A specializes in good $\mathrm{Y}$ while region $\mathrm{B}$ specializes in good $\mathrm{X}$. This distinction between complete specialization of both region versus that of one region becomes crucial later in the empirical work.

Whether such lumpiness is actually prominent phenomenon is an empirical question which a few tried to answer recently. As mentioned above, factor price is 
equalized within the FPE parallelogram. Thus, if one finds the evidence against factor price equalization, then, factor allocation should be in the lumpy area. Bernard, Jensen, and Schott (2001) find the evidence of variations in factor prices across regions in the case of the U.S. They claim that there are at least three cones which have different relative wage rates and that in 83 out of 181 regions, the relative wage deviates from the rest of the regions. From this evidence, they claim that the factor allocation in the U.S. is lumpy (uneven). For other parts of the world, Bernard, Redding, Schott, and Simpson (2002) study the case in the United Kingdom. and find the evidence against the relative factor price equalization. Thus, factor abundance is not uniform within the United Kingdom. ${ }^{15}$ Bernard, Robertson, and Schott (2004) find the evidence in favor of lumpiness in the case of Mexico.

If in fact, factors are significantly unevenly distributed across regions, the implication of trade policy such as tariffs is quite different from the conventional one. Back to the Edgeworth Box above, if labor is lumpy as in the area I, the country as a whole imports good Y, thus, tariff will be imposed on good Y. The effect of the tariff, however, is different between regions A and B. Note, before the tariff is imposed, the wage rate in region $\mathrm{A}$ is higher than in the region $\mathrm{B}$. The factor prices of region $\mathrm{B}$ are equivalent to the world factor prices. The region A, scarce in labor, uses higher capitallabor ratio in producing good $\mathrm{Y}$ than would the factor intensity be prevailed under nonspecialization. The tariff on good $\mathrm{Y}$ will now raise the relative price of good $\mathrm{Y}$, thus, increase the return to labor (as well as capital) in region A. On the other hand, the usual Stolper-Samuelson theory applies to region B. The return to capital increases and the

\footnotetext{
${ }^{15}$ However, Debaere (2004) finds that the difference in factor distribution across the regions in the United Kingdom and Japan is not sufficiently large enough to cause the regions to have different specialization of production at different factor prices.
} 
return to labor decreases as the price of capital intensive good increases. Therefore, we observe a distinct regional effect of tariff: laborers in region A gain while laborers in region B (even those producing the same good as in region A) lose. This heterogeneity of regional impact of trade persists until enough of factors shifts so that the allocation moves into the FPE parallelogram.

The alternative exploration of regional impacts of international trade is done by Melvin (1985). It introduces transportation cost between regions within a country that is so high that regional trade is replaced with international trade. For instance, if transporting commodities from west coast to east coast in the US is more expensive than bringing goods from Canada or Mexico, international trade would take place even if the factor abundance and production technology for Canada and Mexico were the same with the US. The case can be described with the two regional production possibility curves (PPC) in the graph 2.

\section{[Graph 2]}

$\mathrm{X}$ is continuously assumed to be a labor intensive good while $\mathrm{Y}$ to be a capital intensive good. Region W is assumed to be more labor abundant, thus, has more capability to produce good $\mathrm{X}$ than region $\mathrm{E}$ as shown in the graph. Two regions have a same preference in consumption. Thus, they have an identical optimal consumption ratio of good $\mathrm{X}$ and $\mathrm{Y}$. The equilibrium production points for region $\mathrm{E}$ and $\mathrm{W}$ are denoted as $P^{E}$ and $P^{W}$ respectively. The equilibrium consumption point is denoted as A for given the world price. Because of high regional transportation cost, regional economies of $\mathrm{E}$ and $\mathrm{W}$ are independent and regional trade does not occur despite the fact that the demand of good $\mathrm{X}$ in region $\mathrm{E}$ exceeds its own supply and likewise the demand of good $\mathrm{Y}$ in region 
$\mathrm{W}$ exceeds its own supply. Instead, region E exports good $\mathrm{Y}$ to the rest of the world and imports good $\mathrm{X}$, while region $\mathrm{W}$ exports good $\mathrm{X}$ and imports good $\mathrm{Y}$ from abroad. The factor price is identical between two regions at this moment as they face the same world prices of the goods vis-à-vis the Stolper-Samuelson theorem. However, the imposition of a tariff has a different impact on the factor price between the regions since it changes the relative price of the goods in two regions. Suppose that trade volume of region $\mathrm{W}$ is greater than that of region E, thus, the country imposes the tariff on good Y. Note that only region $\mathrm{W}$ imports good $\mathrm{Y}$. Thus, the relative price of good $\mathrm{X}$ to $\mathrm{Y}$ decreases in region $\mathrm{W}$, but stays same in region $\mathrm{E}$ (where it continuously exports good $\mathrm{Y}$ at the world price). The new production point for region $\mathrm{W}$ is denoted as $P_{t}^{W}$, and the consumption point as $\mathrm{B}$. The factor reward to labor (only) in region $\mathrm{W}$ decreases while that in region $\mathrm{E}$ is unaffected. Note that laborers producing the same good now face different factor rewards across regions. Therefore, tariff has distinct impacts among regions in a country. As Melvin (1985) generalizes it in a proposition, "If regions have different trade patterns, any tariff will generate interregional differences in real factor rewards. The abundant factor in each region will lose relatively and absolutely."

In the next section, we provide the empirical setup which we test whether trade policy has differentiated impact on factor rewards (of labor) across regions in the US.

\section{Data and Estimation Strategy}

We use the wage data from the Bureau of Labor Statistics Quarterly Census of Employment and wages. This provides the annual wage per employee between 1990 and 
2001 in the Metropolitan Statistical Areas (MSA) across the industries of NAICS (the North American Industry Classification System). There are currently 370 MSA in the U.S. Each MSA contains at least one urbanized area of 50,000 or more inhabitants. There is a high degree of economic and social integration among the communities in each MSA. Among 370 MSA, 369 were available for the wage data. Table 1 lists the regions in our sample.

\section{[Table 1]}

We transform the data into the average annual wage based on two digit SIC (Standard Industrial Classification) of which the NAICS-SIC concordance is available. This leads us 27 industries across 369 MSA regions throughout the year of 1990 to 2001. The purpose of aggregating at two digit level is to avoid double counting workers, for example, those who produce both "livestock such as beef and hog" (SIC 021) and those who produce "poultry and eggs" (SIC 025). The US tariff data is available based on the Harmonized Tariff Schedule (HTS) for the years 1989 to 2001, which Feenstra, Romalis, and Schott (2002) provides. ${ }^{16}$ The Most Favored Nation rate is used for the tariff measure in the estimation. The Non-Tariff Barrier (NTB) data is available for 1993 to 2000 by Jon Haveman who constructed the database using UNCTAD TRAIN. ${ }^{17}$ We calculate the coverage ratio as the measurement of Non-Tariff Barriers. The coverage ratio is the portion of imports in a particular sector that are subject to at least one NTB. The concordance with SIC, NAICS, and HTS codes are available by Raymond

\footnotetext{
${ }^{16}$ John Romalis generously provides the data at http://gsbwww.uchicago.edu/fac/john.romalis/research/

${ }^{17}$ The Ultimate Trade Barrier Catalog versions 3 is made available at http://www.eiit.org/Protection/
} 
Robertson. ${ }^{18}$ We integrated the data on wage, tariff, and NTB based on two digit SIC.

Due to the limitation of the concordance between SIC and HTS, we have the industries up to SIC 39. We provide the summary statistics in Table 2 for the wage ratio, tariffs, and NTBs across industry.

\section{[Table 2]}

The variations of tariffs and NTBs are over the years while the variation of relative wages is across years and regions. The means of tariffs range from 0 percent in several industries to 12.6 percent, the highest in Apparel and Textile product industry. The means of NTBs coverage ratio range from 0 percent in several industries to 62.3 percent, again the highest in Apparel and Textile product industry. The highest average wage was found in the Metal Mining industry being more than twice as large as its national average. The lowest was found in Agricultural Production of Crops industry with about a half the national average.

To test if trade barriers have a differential effect on wages across regions in the U.S., we develop the following estimation model.

(1) $R W R_{i t r}=\alpha_{0}+\alpha_{1 r} D_{r}+\alpha_{2 i} D_{i}+\alpha_{3}$ Tariff $_{i t}+\alpha_{4} N T B_{i t}$

$$
+\alpha_{5 i} D_{i} \text { Tariff }_{i t}+\alpha_{6 i} D_{i} N T B_{i t}+\alpha_{7 r} D_{r} \text { Tariff }_{i t}+\alpha_{8 r} D_{r} N T B_{i t}+\varepsilon_{i t r}
$$

where we define the relative wage ratio as the wage for a particular industry and year and region relative to the national average wage across industry and region for that year : $R W R_{\text {itr }}=$ Wage $_{\text {itr }} /$ Wage $_{t}$. The subscripts $\mathrm{r}, \mathrm{i}$, and $\mathrm{t}$ represent region, industry, and year.

$D_{r}$ is the regional dummy. $D_{i}$ is the industry dummy. $\alpha_{1 r}$ measures regional fixed

\footnotetext{
${ }^{18}$ Raymond Robertson generously makes the data available at http://www.macalester.edu/research/economics/PAGE/HAVEMAN/Trade.Resources/TradeConcordances. $\mathrm{html}$
} 
effects that are independent of industry and year. The wage in a certain region may be higher or lower than the national average. A region's amenities may prevent labor mobility which eliminates wage discrepancy. Or, regional education that deviates from its national level may make labor more productive compared to the national level. $\alpha_{2 i}$ measures industry specific features that raise or lower the wage rate in certain industry apart from the national average wage. This may be due to high/low value added characteristics of products produced in an industry or due to other production factors such as capital that differentiate marginal product of labor. $\alpha_{3}$ and $\alpha_{4}$ are the effect of tariffs and NTBs on wages for a base region and a base industry. $\alpha_{5 i}$ and $\alpha_{6 i}$ are the industry specific effects of tariffs and NTBs on wages that are on the top of the effects of the base industry.

Our main concerns are $\alpha_{7 r}$ and $\alpha_{8 r}$. The interaction terms of the region dummy, $D_{r}$, with tariff and Non-Tariff Barriers (NTB), Tariff $f_{i t}$ and $N T B_{i t}$, capture the effect of tariff and NTB that are specific to any region. As discussed in the previous section, if regional transportation cost is low enough and/or factor allocation is not lumpy, the impact of trade policies should be homogenous across the regions. Therefore, the null hypothesis of homogeneity of the impact of trade barriers throughout regions can be stated as $\alpha_{7 r}=\alpha_{8 r}=0$ for all regions. If the null is accepted, the differences in factor prices and factor abundance across the regions found in the previous literature are not significantly different enough to have heterogeneous impacts of trade policy across regions. Furthermore, the transportation costs of commodities within the U.S. are not significantly high to deter the regional trade. On the other hand, if the null is rejected, the trade barriers' impacts are not the same among regions. The change in tariff rates leads a 
particular skill of workers to be better off in one region, and the same skill workers worse off in other regions. In this case, the national trade policy has an uneven distributional effect not only among skill workers, but also among regions. The traditional winner/loser argument of trade policy based on the owners of factors should be extended to regions so as to incorporate regional redistribution. The assessment of the welfare analysis of trade policy becomes much more complex.

Before we proceed to the regression results, we make a few notes on the estimation in conjunction with the theories introduced in the previous section. For the lumpiness model by Courant and Deardorff (1992), in a two-good two-region world, if factor allocation is such as in the area II, III, or VI in the graph 1, two regions do not share the production bundle at all. Thus, in our estimation model, there can not be any comparable wage. We believe that we can exclude such extreme cases as we deal with more comprehensive regions and industries in the United States. For the transportation cost model by Melvin (1985), the regions that share borders with Mexico and Canada are expected to have differential impacts of trade barriers compared to other regions as those regions are thought to face much lower international transportation cost than interregional transportation cost.

\section{Results and Discussion}

Due to three dimension data with region, year, and industry, a base region and a base industry must be chosen. The selection of a base region may require some caution since we will test whether all but the base region have the same impacts of trade barriers 
as does the base region. ${ }^{19}$ We first pick a base region randomly and run the regression. It is found that the region with the median value of coefficients $\alpha_{7 r}$ and $\alpha_{8 r}$ is

Harrisonburg, Virginia. Next, we use Harrisonburg as the base region and run the same regression model. The interpretation of all the coefficients, $\alpha_{7 r}$ and $\alpha_{8 r}$, become relative to Harrisonburg. If all the regions cluster close enough to the base region in terms of the effects of trade barriers on wages, then, $\alpha_{7 r}$ and $\alpha_{8 r}$ will be statistically insignificant. On the other hand, if a certain group of regions have had differential impacts of trade barriers, the coefficients of those regions are expected to be statistically significant. ${ }^{20}$ While the sign of these coefficients is not crucial in testing the homogeneous effect of trade barriers, a positive coefficient of a region indicates that the region gains from trade barriers more than the base region, Harrisonburg, Virginia. On the other hand, a negative coefficient indicates that the region incurs losses due to trade barriers compared to the base region. There are 320 coefficients of $\alpha_{7 r}$, the region specific effect of tariff, and 342 coefficients of $\alpha_{8 r}$, the region specific effect of NTB. Here, we should note that the coefficients of tariffs are not comparable to the coefficients of NTB. Our tariff measure is ad valorem rate which is the portion of a unit price. On the other hand, our NTB measure, a coverage ratio does not tell its trade barrier in terms of a portion of a price. For the tariff term, 12 out of 320 regions are significant at least at the 10 percent level. Of those, 4 are significant at the 1 percent level. These MSA include Ames, Iowa; Duluth, Minnesota and Wisconsin; Jackson, Tennessee; and Lake Charles, Louisiana. Another 3 regions are

\footnotetext{
19 The selection of a base industry is, on the other hand, less problematic as the industry specific effect of trade barriers are more of control factors in our paper.

${ }^{20}$ Technically a base region can be any region in the sample. Here, we postulate that all regions are homogenous and they cluster together close enough in terms of factor abundance, and thus, the impacts of trade barriers. Based on this presumption, the method is intended to provide the fewest regions with statistically significant coefficients. For this part, I am indebted to Strat Douglas.
} 
significant at the 5 percent level, which include Bloomington-Normal, Illinois;

Parkersburg-Marietta, West Virginia and Ohio; and San Angelo, Texas. Of seven regions with at least a 5 percent significance level, Ames, Iowa and Bloomington-Normal Illinois had negative coefficients while the other five had positive coefficients. The largest negative significant coefficient was - 33 in Ames, Iowa. With the increase (decrease) in tariff by 1 percentage point, the relative wage is lowered (increased) by 0.33 compared to the base region, Harrisonburg, Virginia. The largest positive significant coefficient was 32.8 in Jackson, Tennessee. Again, the 1 percentage point increase (decrease) in (all) tariff will raise (lower) the relative wage in Jackson by 0.328 compared to that in Harrisonburg.

For the NTB term, 21 out of 342 regions are significant at least at the 10 percent level. Of those, four are significant at the 1 percent level. These MSA include Ames, Iowa; Duluth, Minnesota and Wisconsin; Fargo, North Dakota and Minnesota; and Racine, Wisconsin. Another eleven regions are significant at the 5 percent level. Those include Bay City, Michigan; Bloomington, Indiana; Boulder, Colorado; CantonMassillon, Ohio; Danville, Illinois; Kalamazoo-Portage, Michigan; Lafayette, Indiana; Niles-Benton Harbor, Michigan; San Jose-Sunnyvale-Santa Clara, California; Syracuse, New York; Tulsa, Oklahoma. About one half of the regions have positive coefficients and the other half negative. The largest positive significant coefficient is 3.797 in Duluth, Minnesota and Wisconsin. A 10 percentage point increase (decrease) in the coverage ratio will increase (decrease) the relative wage in Duluth by 0.38 compared to that in Harrisonburg. The largest negative significant coefficient is -2.219 in Bloomington, 
Indiana. A 10 percentage point increase (decrease) in the coverage ratio will decrease (increase) the relative wage in Bloomington by 0.22 compared to that in Harrisonburg. When looking at each coefficient estimate of the regions discussed above, one finds few regions with statistically significant estimates. For the purpose of the analysis to test if no region has differential impacts from trade barriers, an F-test is conducted. The joint F-test of $\alpha_{7 r}=\alpha_{8 r}=0$ for all regions is rejected at less than 1 percent significance level with an F-statistics of 3.18. Therefore, the notion that tariff and NTB have had homogenous impacts among the regions in the U.S. between 1993 and 2000 is rejected. This leaves a somewhat puzzling fact in which the F-test indicates there are heterogeneous regional impacts while individual regional coefficient estimates indicate there is not much of regional impact. While the joint F-test above focuses the trade barriers all together, it should be noted that there is clear distinction in our measurements between tariff and NTB. The magnitude of a trade barrier by a tariff is measured with ad valorem equivalent rate which is in terms of the proportion of the domestic price. On the other hand, the coverage ratio, our measure of a NTB, is the portion of imports that are subject to NTB, and it does not tell the magnitude of the trade barrier in terms of the portion of domestic price. For this reason, we also tested separately for tariffs and NTBs if each has had homogeneous regional impacts. In other words, we tested two null hypotheses, $\alpha_{7 r}=0$ and $\alpha_{8 r}=0$ separately. We found that both are rejected at less than the 1 percent significance level with F-statistics of 4.02 and 2.01 respectively. Thus, even when tariffs and NTBs are analyzed separately by acknowledging two distinct measurements, it is still found that the impacts of trade barriers are heterogeneous across the regions. 
In Bernard, Jensen, Schott (2001), about 46 percent of the Labor Market Area (LMA) in the United States is found to have different relative wage rates in 1992. About the half of the sample regions had different wage rates from the overall U.S. rate at 10 percent significant level. However, they also found that between 1972 and 1992, the discrepancy of wages among the regions narrowed. If this trend has continued during our sample period of 1993 to 2000 , the fact that we found very little regions with differential regional impacts of trade barriers may reflect this narrowing trend of the discrepancy among the regions.

Although our empirical study is not meant to identify the cause of heterogeneous impacts of trade barriers, we provide some implication of our results regarding the theories discussed previously. In Melvin (1985), the cause of differential trade patterns across regions is high inter-regional transportation cost relative to international transportation cost. The regions bordering Mexico and Canada are thus expected to have different trade pattern than the rest of the regions in the U.S. Those regions include ones in the states such as Washington, Idaho, Montana, North Dakota, Minnesota, Wisconsin, Michigan, Ohio, Pennsylvania, New York, Vermont, Maine, New Hampshire, California, Arizona, New Mexico, and Texas. ${ }^{21}$ In our sample regions, there are 149 (out of 369) regions that are located in these seventeen states. They are expected to have differential impacts of trade barriers from the rest of the regions since the cost of transporting goods to Mexico or Canada for these regions may be much lower than domestic transportation costs. Among 33 coefficients found significant with at least at the 10 percent level, 17 regions belong to the 17 states mentioned above. Other 16 coefficients are found in the

\footnotetext{
${ }^{21}$ Of course one should proceed more rigorous investigation involved with geographic analysis to define the border regions and the non-border regions.
} 
states such as Illinois, Indiana, Alabama, Arkansas, Tennessee, Oklahoma, Colorado, and Iowa. Approximately 11.4 percent of the border regions (17 out of 149 regions) have significant coefficients, while about 7.3 percent of the non-border regions (16 out of 220 regions) have significant coefficients. Are the two numbers 11.4 and 7.3 statistically different? Is the percentage for the border regions larger than that for the non-border regions and enough to be able to distinguish the former from the latter as Melvin (1985) predicts? Cox (1987) summarizes a test statistic that allows us to examine the statistical difference between two proportions. The test statistic follows the normal distribution and can be written as

$$
z=\frac{p_{1}-p_{2}}{\sqrt{p(1-p)\left(n_{1}+n_{2}\right) / n_{1} n_{2}}}
$$

where $p_{1}$ and $p_{2}$ are the two proportions, 11.4 percent and 7.3 percent. $n_{1}$ and $n_{2}$ are the sample size, 149 and 220 regions respectively. $p$ is the total proportion of the regions that have significant coefficients, that is 8.9 percent ( 33 out of 369 regions). The null hypothesis is that the proportion of significant coefficients in the border regions is less than or same as that in the non-border regions. The alternative hypothesis is that the border regions have a larger proportion of regions with significant coefficients. The calculated test statistic is 1.366 and the p-value is 0.0859 . We can reject the null at the 10 percent with a one-tailed test. Thus, there seems to be the evidence that the border regions have differential impacts of trade barriers compared to the rest of the regions as Melvin (1985) hypothesized.

The alternative theory, Courant and Deardorff (1992) and more recent Bernard, Jensen, and Schott (2001), relies on the fact that factor abundance varies across the 
regions and the regions belong in different cones. To examine whether this is a cause of differential impacts of trade barriers, one need to examine the factor abundance and the bundles of goods with specialization for the regions our study finds to have significant coefficients. This is left for future research.

A brief examination of other coefficients in the estimation is provided below. About one fifth of the regional dummy, $\alpha_{1 r}$, are significant with at least at the 5 percent level. This regional fixed effects goes beyond industry fixed effects and the trade barriers effects on wages. Such wage deviation that goes beyond industrial structure in each region may stem from regional amenity that can differentiate the wages or labor immobility that wage differences alone do not motivate people to change their habitation. Fifty-three regions have negative coefficients while eleven are positive. The base region is Harrisonburg, Virginia. Thus, the regions with negative coefficients have the wage rates on average below that in Harrisonburg, while the opposite is true for the regions with positive coefficients. Sixteen of the industry dummies, $\alpha_{2 i}$, are statistically significant, of which three are negative and 13 are positive. The base industry is SIC code 39 Miscellaneous Manufacturing Industries, which include manufacturing of jewelry, musical instruments, toys, and office supplies. Compared to the wage rates in this category, the industries with negative coefficients have lower wages on average. These include Agricultural production of crops and livestock and forestry industry. The industries that had higher wages than the base industry are Industrial Machinery Equipment and Electronic Equipment, Chemical, Petroleum, and Coal Product, Mining, Paper Product, etc. 
The industry interaction term with trade barriers, $\alpha_{5 i}$ and $\alpha_{6 i}$ measures the impacts of trade barriers that are specific to industries. Four industries are found statistically significant in $\alpha_{5 i}$, tariff term, two positive and the other two negative. The industries with negative coefficients, Electronic Equipment and Instruments and Related Products, have not gained from tariffs on average compared to the base industry, while the industries with positive coefficients, Metal Mining and Paper and Allied Products, gained more. For NTB term, $\alpha_{6 i}$, one was found statistically significant and negative in Metal Mining industry. In principle, the same percentage change in goods price due to tariffs are expected to provide the equal gain in revenue per unit and if every industry passes the gain to laborers in the same manner, there should not be any industry specific impacts of trade barriers. The fact that we found several significant coefficients of these may be representing the different structure of industry in a way that they pass gains to laborers. For NTB, Metal Mining industry, one found significant, may have differentiated impact of trade barriers on its product price, and thus, differential impact on wages. Much of the details of these, however, should be considered with industrial and market structures. The lists of the estimates of $\alpha_{5 i}$ and $\alpha_{6 i}$ are in the Table 3.

\section{[Table 3]}

\section{Conclusion}

Conventionally, trade economists have treated a country as a point without space. In other word, we assumed factors of production are perfectly mobile between regions within a country, and same production technologies are equally available among the regions. Consumers' taste of goods and services and their incomes are also assumed to be 
identical across the regions. Under these assumptions, there is no need to consider regional effects of trade since it affects all regions equally. The conventional focus of how trade influences a country was, hence, its impacts on factors or a nation as a whole. Likewise, the effects of tariff and other trade policies are assumed to be homogenous within a country. A couple literatures provide the theoretical rationales on how international trade can affect regions differently. First, Courant and Deardorff (1992) explain how factor allocation among regions can be a key determinant of what goods the country produces and trades with the rest of the world. That is, when resources are distributed unevenly across regions, the regions will have comparative advantage on different sets of goods. Second, Melvin (1985) studies the case where regional economies face such high transportation cost that it replaces regional trade with international trade. It shows regions will have different trade patterns unless resource allocation is exactly identical among the regions. In both cases, tariff and other trade barriers affect regions differently. The reward to the same factor can increase in one region and decrease in another region due to changes in trade policies. This paper is motivated by these theoretical developments as well as the recent empirical evidences of uneven factor allocation. We conduct the empirical scrutiny on whether trade policies have affected US regions differently. We use both tariff and Non-Tariff Barrier (NTB) measure to reflect the recent increase in the importance of the NTB as trade barriers. Our results provide some evidence, though weak, that both tariff and NTB had different impacts on wages across the regions. This indicates that trade policy creates gains and losses for the same factor owners across different regions. The number of regions with distinct impacts from NTB exceeds the respective number for tariff showing an increasing role of NTB over 
tariff in the protection of domestic firms. The evidence is weak when one looks into individual coefficient estimates of each region as it seems that there are very few regions, if any, that have differential impacts of trade barriers. This may possibly indicate that the U.S. labor markets in the examined regions are more highly if not completely integrated than previously thought concerning the impacts of international trade. In fact, Debaere (2004) finds that the factor allocation is quite even in the case of the United Kingdom and Japan, in which case trade barriers should not have any regional impact. Is the United States different? Our study is the first attempt in the literature to examine whether trade barriers affect domestic regions differently, and more research is desired in future. One way of extension in this study is to employ an alternative empirical model by examining whether the share of labor income is equalized across regions and whether trade barriers have created the difference in the share of labor income across regions. The method is proposed in Bernard et al. (2001) and, though a CES production function is assumed, it provides an alternative empirical examination.

Finally, in our study, we demonstrated the existence of regional impacts of trade policies. However, we did not examine whether the losses from trade barriers are borne by the owners of the abundant factor in each region as the previous theoretical studies have indicated. The question has to be answered in conjunction with the recent empirical evidence of the uneven factor distribution and the failure of Factor Price Equalization. In addition, we did not test whether this is due lumpiness of factor allocation or transportation cost that resulted in the regional impacts of trade barriers. These questions are left for future research. 


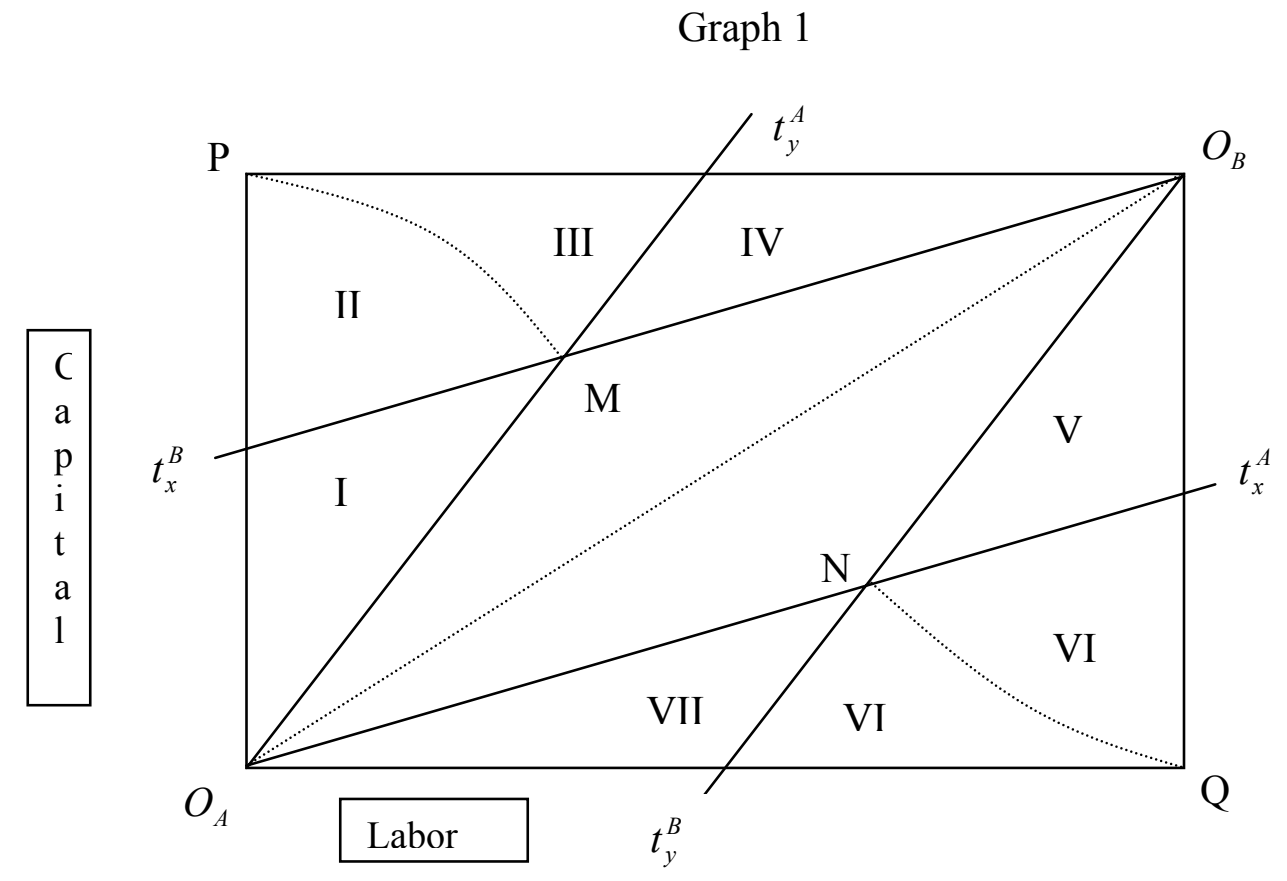




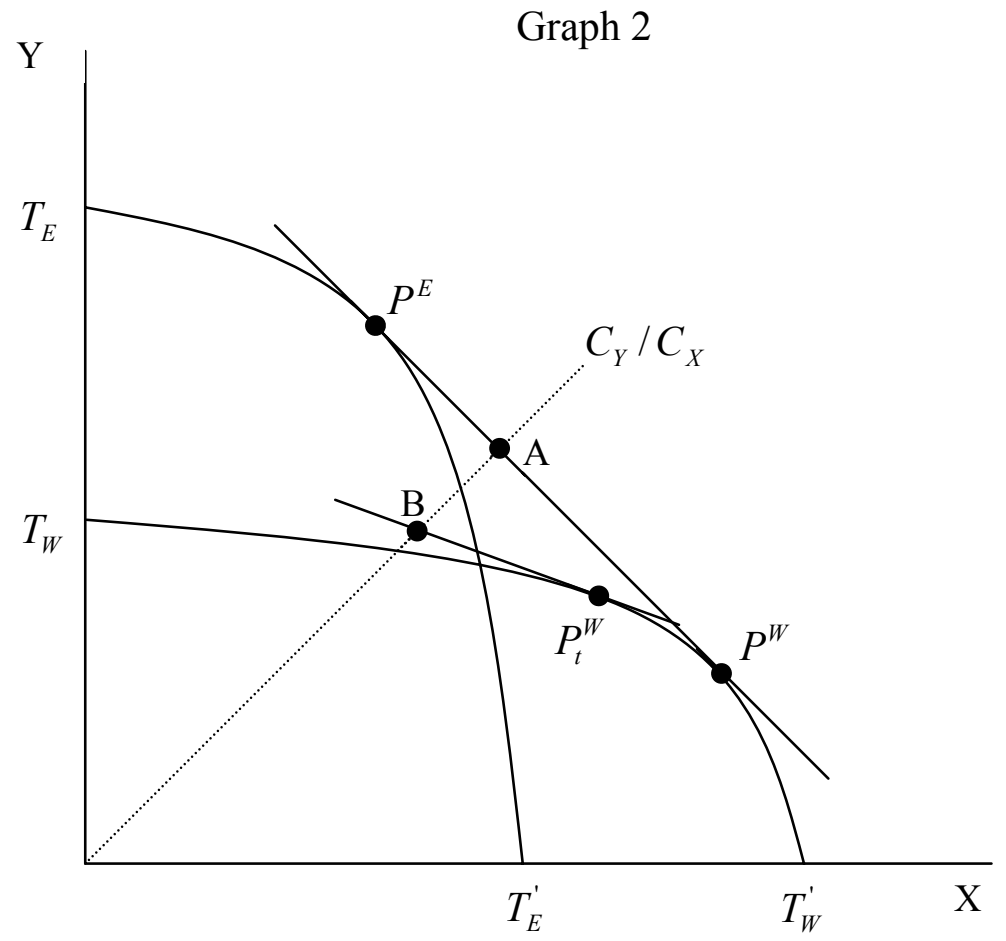




\section{Table 1 The list of US regions}

$\begin{aligned} 1 & \text { Abilene TX } \\ 2 & \text { Aguadilla-Isabela-San Sebastián PR } \\ 3 & \text { Akron OH } \\ 4 & \text { Albany GA } \\ 5 & \text { Albany-Schenectady-Troy NY } \\ 6 & \text { Albuquerque NM } \\ 7 & \text { Alexandria LA } \\ 8 & \text { Allentown-Bethlehem-Easton PA-NJ } \\ 9 & \text { Altoona PA } \\ 10 & \text { Amarillo TX } \\ 11 & \text { Ames IA } \\ 12 & \text { Anchorage AK } \\ 13 & \text { Anderson IN } \\ 14 & \text { Anderson SC } \\ 15 & \text { Ann Arbor MI } \\ 16 & \text { Anniston-Oxford AL } \\ 17 & \text { Appleton WI } \\ 18 & \text { Asheville NC } \\ 19 & \text { Athens-Clarke County GA } \\ 20 & \text { Atlanta-Sandy Springs-Marietta GA } \\ 21 & \text { Atlantic City NJ } \\ 22 & \text { Auburn-Opelika AL } \\ 23 & \text { Augusta-Richmond County GA-SC } \\ 24 & \text { Austin-Round Rock TX } \\ 25 & \text { Bakersfield CA }\end{aligned}$

26 Baltimore-Towson MD

27 Bangor $\mathrm{ME}$

28 Barnstable Town MA

29 Baton Rouge LA

30 Battle Creek MI

31 Bay City MI

32 Beaumont-Port Arthur TX

33 Bellingham WA

34 Bend OR

35 Billings MT

36 Binghamton NY

37 Birmingham-Hoover AL

38 Bismarck ND

39 Blacksburg-Christiansburg-Radford VA

40 Bloomington IN

41 Bloomington-Normal IL

42 Boise City-Nampa ID

43 Boston-Cambridge-Quincy MA-NH

44 Boulder $\mathrm{CO}$

45 Bowling Green KY

46 Bremerton-Silverdale WA

47 Bridgeport-Stamford-Norwalk CT

48 Brownsville-Harlingen TX

49 Brunswick GA

50 Buffalo-Niagara Falls NY
51 Burlington $\mathrm{NC}$

52 Burlington-South Burlington VT

53 Canton-Massillon $\mathrm{OH}$

54 Cape Coral-Fort Myers FL

55 Carson City NV

56 Casper WY

57 Cedar Rapids IA

58 Champaign-Urbana IL

59 Charleston WV

60 Charleston-North Charleston SC

61 Charlotte-Gastonia-Concord NC-SC

62 Charlottesville VA

63 Chattanooga TN-GA

64 Cheyenne WY

65 Chicago-Naperville-Joliet IL-IN-WI

66 Chico CA

67 Cincinnati-Middletown OH-KY-IN

68 Clarksville TN-KY

69 Cleveland TN

70 Cleveland-Elyria-Mentor $\mathrm{OH}$

71 Coeur d'Alene ID

72 College Station-Bryan TX

73 Colorado Springs CO

74 Columbia MO

75 Columbia SC 


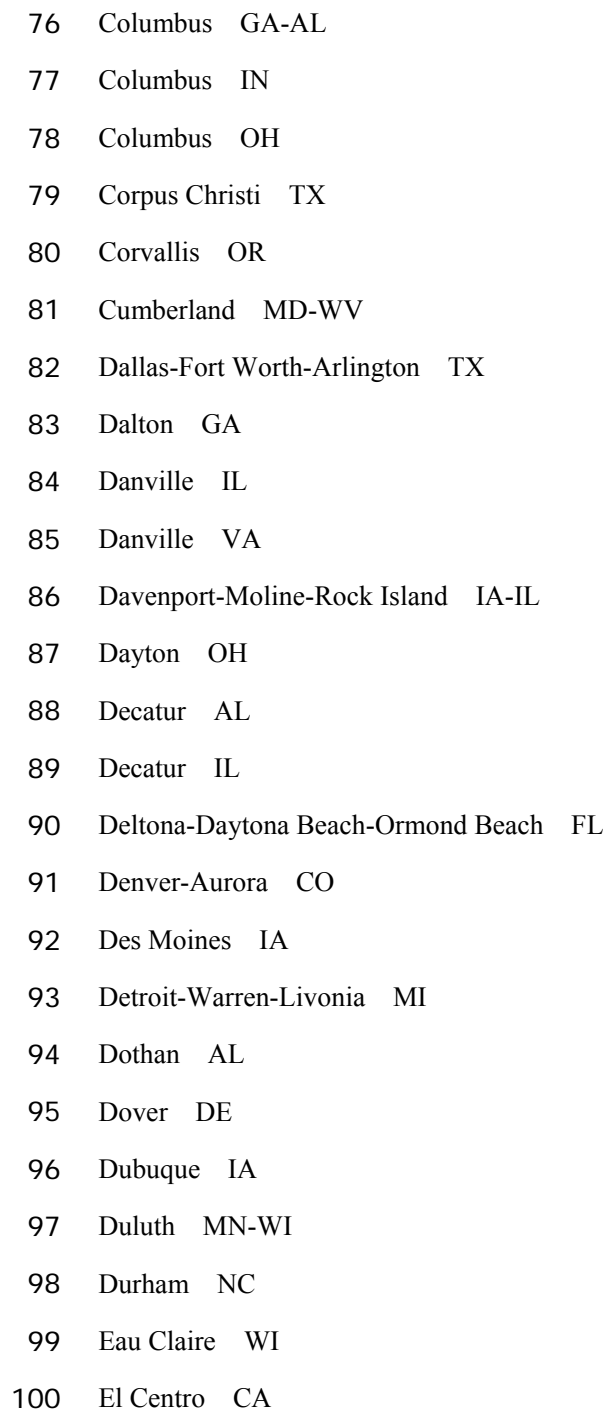

126 Gainesville GA

127 Glens Falls NY

128 Goldsboro NC

129 Grand Forks ND-MN

130 Grand Junction CO

131 Grand Rapids-Wyoming MI

132 Great Falls MT

133 Greeley CO

134 Green Bay WI

135 Greensboro-High Point NC

136 Greenville NC

137 Greenville SC

138 Guayama PR

139 Gulfport-Biloxi MS

140 Hagerstown-Martinsburg MD-WV

141 Hanford-Corcoran CA

142 Harrisburg-Carlisle PA

143 Harrisonburg VA

144 Hartford-West Hartford-East Hartford CT

145 Hattiesburg MS

146 Hickory-Lenoir-Morganton NC

147 Hinesville-Fort Stewart GA

148 Holland-Grand Haven MI

149 Honolulu HI

150 Hot Springs AR 


\begin{tabular}{ll}
151 & Houma-Bayou Cane-Thibodaux LA \\
152 & Houston-Baytown-Sugar Land TX \\
153 & Huntington-Ashland WV-KY-OH \\
154 & Huntsville AL \\
155 & Idaho Falls ID \\
156 & Indianapolis IN \\
157 & Iowa City IA \\
158 & Ithaca NY \\
159 & Jackson MI \\
160 & Jackson MS \\
161 & Jackson TN \\
162 & Jacksonville FL \\
163 & Jacksonville NC \\
164 & Janesville WI \\
165 & Jefferson City MO \\
166 & Johnson City TN \\
167 & Johnstown PA \\
168 & Jonesboro AR \\
169 & Joplin MO \\
170 & Kalamazoo-Portage MI \\
171 & Kankakee-Bradley IL \\
172 & Kansas City MO-KS \\
173 & Kennewick-Richland-Pasco WA \\
174 & Killeen-Temple-Fort Hood TX \\
\hline 175 & Kingsport-Bristol-Bristol TN-VA \\
\hline 15
\end{tabular}

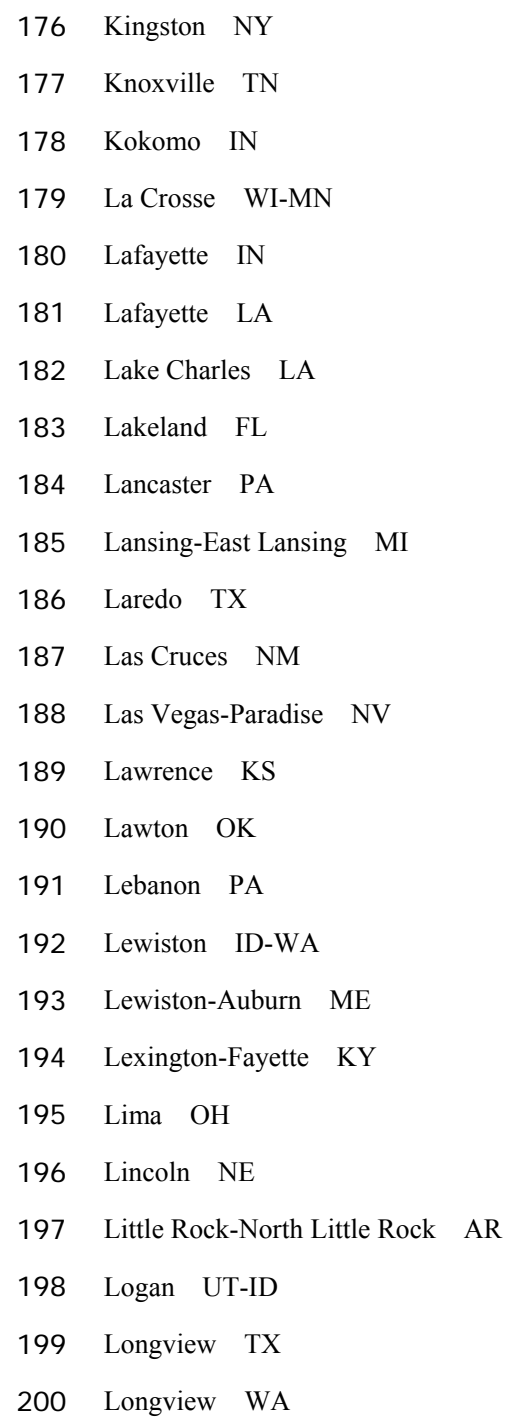

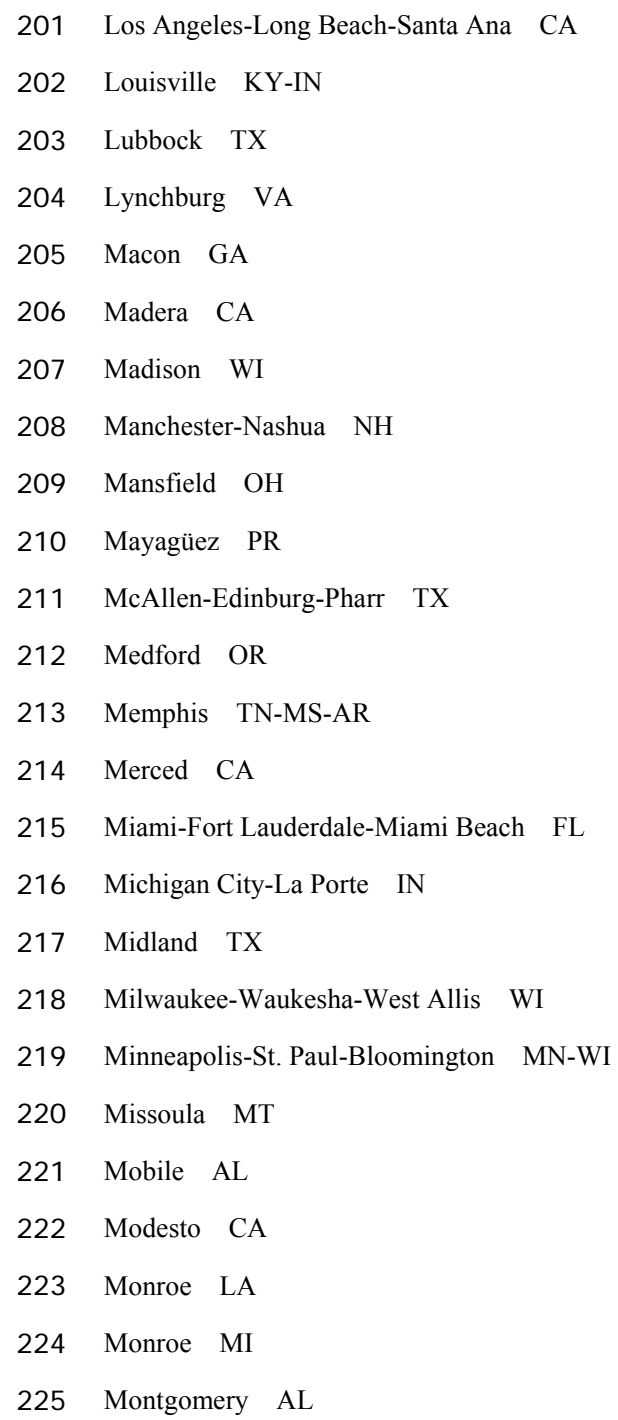




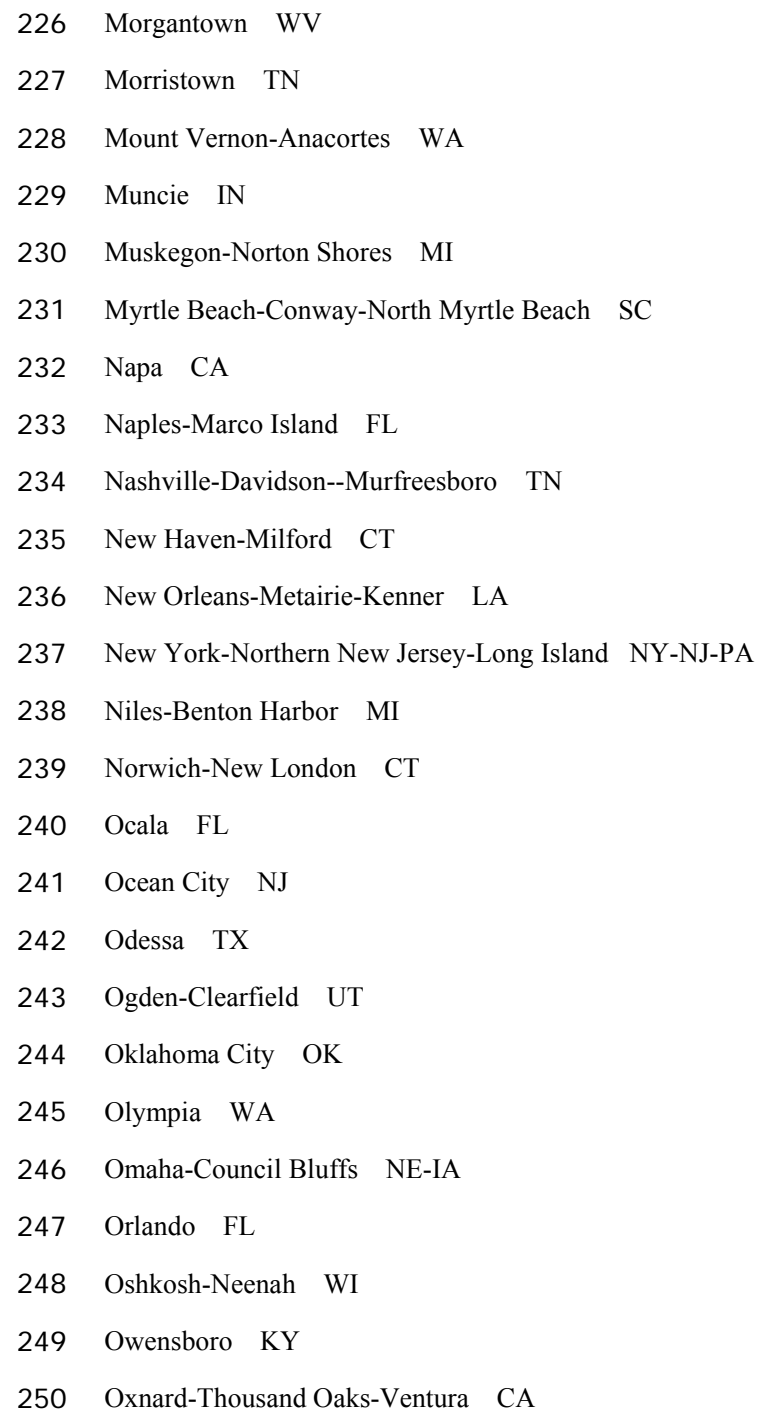

251 Palm Bay-Melbourne-Titusville FL

252 Panama City-Lynn Haven FL

253 Parkersburg-Marietta WV-OH

254 Pascagoula MS

255 Pensacola-Ferry Pass-Brent FL

256 Peoria IL

257 Philadelphia-Camden-Wilmington PA-NJ-DE-MD

258 Phoenix-Mesa-Scottsdale AZ

259 Pine Bluff AR

260 Pittsburgh PA

261 Pittsfield MA

262 Pocatello ID

263 Ponce PR

264 Portland-South Portland-Biddeford ME

265 Portland-Vancouver-Beaverton OR-WA

266 Port St. Lucie-Fort Pierce FL

267 Poughkeepsie-Newburgh-Middletown NY

268 Prescott AZ

269 Providence-New Bedford-Fall River RI-MA

270 Provo-Orem UT

271 Pueblo CO

272 Punta Gorda FL

273 Racine WI

274 Raleigh-Cary NC

275 Rapid City SD
276 Reading PA

277 Redding CA

278 Reno-Sparks NV

279 Richmond VA

280 Riverside-San Bernardino-Ontario CA

281 Roanoke VA

282 Rochester MN

283 Rochester NY

284 Rockford IL

285 Rocky Mount NC

286 Rome GA

287 Sacramento--Arden-Arcade--Roseville CA

288 Saginaw-Saginaw Township North MI

289 St. Cloud MN

290 St. George UT

291 St. Joseph MO-KS

292 St. Louis MO-IL

293 Salem OR

294 Salinas CA

295 Salisbury MD

296 Salt Lake City UT

297 San Angelo TX

298 San Antonio TX

299 San Diego-Carlsbad-San Marcos CA

300 Sandusky $\mathrm{OH}$ 
301 San Francisco-Oakland-Fremont CA

302 San Germán-Cabo Rojo PR

303 San Jose-Sunnyvale-Santa Clara CA

304 San Juan-Caguas-Guaynabo PR

305 San Luis Obispo-Paso Robles CA

306 Santa Barbara-Santa Maria-Goleta CA

307 Santa Cruz-Watsonville CA

308 Santa Fe NM

309 Santa Rosa-Petaluma CA

310 Sarasota-Bradenton-Venice FL

311 Savannah GA

312 Scranton--Wilkes-Barre PA

313 Seattle-Tacoma-Bellevue WA

314 Sheboygan WI

315 Sherman-Denison TX

316 Shreveport-Bossier City LA

317 Sioux City IA-NE-SD

318 Sioux Falls SD

319 South Bend-Mishawaka IN-MI

320 Spartanburg SC

321 Spokane WA

322 Springfield IL

323 Springfield MA

324 Springfield MO

325 Springfield $\mathrm{OH}$
326 State College PA

327 Stockton CA

328 Sumter SC

329 Syracuse NY

330 Tallahassee FL

331 Tampa-St. Petersburg-Clearwater FL

332 Terre Haute IN

333 Texarkana TX-Texarkana AR

334 Toledo $\mathrm{OH}$

335 Topeka KS

336 Trenton-Ewing NJ

337 Tucson AZ

338 Tulsa OK

339 Tuscaloosa AL

340 Tyler TX

341 Utica-Rome NY

342 Valdosta GA

343 Vallejo-Fairfield CA

344 Vero Beach FL

345 Victoria TX

346 Vineland-Millville-Bridgeton NJ

347 Virginia Beach-Norfolk-Newport News VA-NC

348 Visalia-Porterville CA

349 Waco TX

350 Warner Robins GA
351 Washington-Arlington-Alexandria DC-VA-MD-WV

352 Waterloo-Cedar Falls IA

353 Wausau WI

354 Weirton-Steubenville WV-OH

355 Wenatchee WA

356 Wheeling WV-OH

357 Wichita KS

358 Wichita Falls TX

359 Williamsport PA

360 Wilmington $\mathrm{NC}$

361 Winchester VA-WV

362 Winston-Salem NC

363 Worcester MA

364 Yakima WA

365 Yauco PR

366 York-Hanover PA

367 Youngstown-Warren-Boardman OH-PA

368 Yuba City CA

369 Yuma AZ 
Table 2 Summary Statistics

\section{Relative Wage}

SIC code

01 AGRICULTURAL PRODUCTION CROPS

02 AGRICULTURAL PRODUCTION LIVESTOCK

08 FORESTRY

09 FISHING, HUNTING, AND TRAPPING

10 METAL MINING

12 COAL MINING

13 OIL AND GAS EXTRACTION

14 NONMETALLIC MINERALS, EXCEPT FUELS

20 FOOD AND KINDRED PRODUCTS

22 TEXTILE MILL PRODUCTS

23 APPAREL AND OTHER TEXTILE PRODUCTS

24 LUMBER AND WOOD PRODUCTS

25 FURNITURE AND FIXTURES

26 PAPER AND ALLIED PRODUCTS

27 PRINTING AND PUBLISHING

28 CHEMICALS AND ALLIED PRODUCTS

29 PETROLEUM AND COAL PRODUCTS

30 RUBBER AND MISC. PLASTICS PRODUCTS

31 LEATHER AND LEATHER PRODUCTS

32 STONE, CLAY, AND GLASS PRODUCTS

33 PRIMARY METAL INDUSTRIES

34 FABRICATED METAL PRODUCTS

35 INDUSTRIAL MACHINERY AND EQUIPMENT

36 ELECTRONIC + OTHER ELECTRIC EQUIPMENT

37 TRANSPORTATION EQUIPMENT

38 INSTRUMENTS AND RELATED PRODUCTS

39 MISCELLANEOUS MANUFACTURING INDUSTRIES

$\begin{array}{rrrrr}\text { N } & \text { Mean } & \text { Std Dev } & \text { Minimum } & \text { Maximum } \\ 852 & 0.517 & 0.152 & 0.097 & 1.134 \\ 761 & 0.606 & 0.174 & 0.147 & 1.897 \\ 599 & 0.691 & 0.272 & 0.295 & 3.200 \\ 86 & 0.979 & 0.459 & 0.336 & 2.517 \\ 14 & 2.790 & 1.410 & 1.382 & 5.298 \\ 22 & 1.564 & 0.241 & 0.976 & 1.972 \\ 377 & 1.332 & 0.434 & 0.557 & 3.355 \\ 401 & 1.100 & 0.252 & 0.478 & 1.827 \\ 861 & 0.821 & 0.269 & 0.273 & 2.843 \\ 139 & 0.857 & 0.195 & 0.303 & 1.370 \\ 197 & 0.692 & 0.173 & 0.334 & 1.106 \\ 1142 & 0.763 & 0.185 & 0.363 & 1.712 \\ 276 & 0.927 & 0.228 & 0.411 & 1.702 \\ 467 & 1.154 & 0.166 & 0.679 & 1.744 \\ 1877 & 0.902 & 0.224 & 0.296 & 2.040 \\ 448 & 1.477 & 0.559 & 0.648 & 8.998 \\ 161 & 1.727 & 0.372 & 1.106 & 2.742 \\ 371 & 0.995 & 0.262 & 0.315 & 2.062 \\ 168 & 0.597 & 0.137 & 0.334 & 1.091 \\ 1010 & 1.007 & 0.194 & 0.275 & 1.679 \\ 311 & 1.146 & 0.292 & 0.589 & 2.263 \\ 1035 & 1.023 & 0.228 & 0.217 & 2.242 \\ 1543 & 1.071 & 0.333 & 0.208 & 6.116 \\ 542 & 1.268 & 0.374 & 0.542 & 4.485 \\ 627 & 1.122 & 0.326 & 0.460 & 2.229 \\ 538 & 1.366 & 0.414 & 0.497 & 5.872 \\ 1468 & 0.828 & 0.180 & 0.313 & 1.847\end{array}$




\section{Tariff}

\begin{tabular}{ll} 
& \multicolumn{1}{c}{ SIC code } \\
01 & AGRICULTURAL PRODUCTION CROPS \\
02 & AGRICULTURAL PRODUCTION LIVESTOCK \\
08 & FORESTRY \\
09 & FISHING, HUNTING, AND TRAPPING \\
10 & METAL MINING \\
12 & COAL MINING \\
13 & OIL AND GAS EXTRACTION \\
14 & NONMETALLIC MINERALS, EXCEPT FUELS \\
20 & FOOD AND KINDRED PRODUCTS \\
22 & TEXTILE MILL PRODUCTS \\
23 & APPAREL AND OTHER TEXTILE PRODUCTS \\
24 & LUMBER AND WOOD PRODUCTS \\
25 & FURNITURE AND FIXTURES \\
26 & PAPER AND ALLIED PRODUCTS \\
27 & PRINTING AND PUBLISHING \\
28 & CHEMICALS AND ALLIED PRODUCTS \\
29 & PETROLEUM AND COAL PRODUCTS \\
30 & RUBBER AND MISC. PLASTICS PRODUCTS \\
31 & LEATHER AND LEATHER PRODUCTS \\
32 & STONE, CLAY, AND GLASS PRODUCTS \\
33 & PRIMARY METAL INDUSTRIES \\
34 & FABRICATED METAL PRODUCTS \\
35 & INDUSTRIAL MACHINERY AND EQUIPMENT \\
36 & ELECTRONIC + OTHER ELECTRIC EQUIPMENT \\
\hline 39 & TRANSPORTATION EQUIPMENT \\
\hline
\end{tabular}

$\begin{array}{rrrrr}\mathbf{N} & \text { Mean } & \text { Std Dev } & \text { Minimum } & \text { Maximum } \\ 852 & 0.014 & 0.006 & 0.007 & 0.022 \\ 761 & 0.000 & 0.000 & 0.000 & 0.000 \\ 599 & 0.000 & 0.000 & 0.000 & 0.000 \\ 86 & 0.005 & 0.004 & 0.000 & 0.011 \\ 14 & 0.002 & 0.005 & 0.000 & 0.013 \\ 22 & 0.000 & 0.000 & 0.000 & 0.000 \\ 377 & 0.000 & 0.000 & 0.000 & 0.000 \\ 401 & 0.000 & 0.000 & 0.000 & 0.000 \\ 861 & 0.015 & 0.010 & 0.004 & 0.030 \\ 139 & 0.109 & 0.004 & 0.104 & 0.114 \\ 197 & 0.126 & 0.018 & 0.100 & 0.150 \\ 1142 & 0.000 & 0.000 & 0.000 & 0.000 \\ 276 & 0.020 & 0.017 & 0.000 & 0.040 \\ 467 & 0.015 & 0.006 & 0.008 & 0.022 \\ 1877 & 0.000 & 0.000 & 0.000 & 0.000 \\ 448 & 0.039 & 0.002 & 0.037 & 0.042 \\ 161 & 0.006 & 0.001 & 0.003 & 0.007 \\ 371 & 0.053 & 0.000 & 0.053 & 0.053 \\ 168 & 0.085 & 0.001 & 0.083 & 0.085 \\ 1010 & 0.043 & 0.005 & 0.037 & 0.049 \\ 311 & 0.037 & 0.010 & 0.024 & 0.049 \\ 1035 & 0.037 & 0.007 & 0.029 & 0.046 \\ 1543 & 0.019 & 0.015 & 0.000 & 0.037 \\ 542 & 0.030 & 0.012 & 0.013 & 0.042 \\ 627 & 0.028 & 0.003 & 0.025 & 0.031 \\ 538 & 0.031 & 0.010 & 0.017 & 0.040 \\ 1468 & 0.039 & 0.009 & 0.029 & 0.051\end{array}$




\section{NTB}

\begin{tabular}{ll} 
& \multicolumn{1}{c}{ SIC code } \\
01 & AGRICULTURAL PRODUCTION CROPS \\
02 & AGRICULTURAL PRODUCTION LIVESTOCK \\
08 & FORESTRY \\
09 & FISHING, HUNTING, AND TRAPPING \\
10 & METAL MINING \\
12 & COAL MINING \\
13 & OIL AND GAS EXTRACTION \\
14 & NONMETALLIC MINERALS, EXCEPT FUELS \\
20 & FOOD AND KINDRED PRODUCTS \\
22 & TEXTILE MILL PRODUCTS \\
23 & APPAREL AND OTHER TEXTILE PRODUCTS \\
24 & LUMBER AND WOOD PRODUCTS \\
25 & FURNITURE AND FIXTURES \\
26 & PAPER AND ALLIED PRODUCTS \\
27 & PRINTING AND PUBLISHING \\
28 & CHEMICALS AND ALLIED PRODUCTS \\
29 & PETROLEUM AND COAL PRODUCTS \\
30 & RUBBER AND MISC. PLASTICS PRODUCTS \\
31 & LEATHER AND LEATHER PRODUCTS \\
32 & STONE, CLAY, AND GLASS PRODUCTS \\
33 & PRIMARY METAL INDUSTRIES \\
34 & FABRICATED METAL PRODUCTS \\
35 & INDUSTRIAL MACHINERY AND EQUIPMENT \\
36 & ELECTRONIC + OTHER ELECTRIC EQUIPMENT \\
37 & TRANSPORTATION EQUIPMENT \\
38 & INSTRUMENTS AND RELATED PRODUCTS \\
39 & MISCELLANEOUS MANUFACTURING \\
INDUSTRIES
\end{tabular}

\begin{tabular}{rrrrr}
\multicolumn{1}{r}{ N } & Mean & Std Dev & Minimum & Maximum \\
852 & 0.431 & 0.173 & 0.259 & 0.642 \\
761 & 0.457 & 0.472 & 0.000 & 0.998 \\
599 & 0.053 & 0.062 & 0.000 & 0.134 \\
86 & 0.165 & 0.178 & 0.000 & 0.381 \\
14 & 0.003 & 0.005 & 0.000 & 0.014 \\
22 & 0.000 & 0.000 & 0.000 & 0.000 \\
377 & 0.175 & 0.299 & 0.000 & 0.896 \\
401 & 0.025 & 0.031 & 0.000 & 0.080 \\
861 & 0.547 & 0.269 & 0.180 & 0.855 \\
139 & 0.329 & 0.215 & 0.001 & 0.571 \\
197 & 0.623 & 0.335 & 0.000 & 0.950 \\
1142 & 0.348 & 0.401 & 0.000 & 0.815 \\
276 & 0.002 & 0.002 & 0.000 & 0.004 \\
467 & 0.000 & 0.000 & 0.000 & 0.001 \\
1877 & 0.000 & 0.001 & 0.000 & 0.001 \\
448 & 0.230 & 0.229 & 0.000 & 0.505 \\
161 & 0.417 & 0.483 & 0.000 & 0.983 \\
371 & 0.085 & 0.048 & 0.000 & 0.160 \\
168 & 0.121 & 0.072 & 0.000 & 0.231 \\
1010 & 0.028 & 0.013 & 0.000 & 0.046 \\
311 & 0.128 & 0.146 & 0.000 & 0.375 \\
1035 & 0.148 & 0.126 & 0.000 & 0.348 \\
1543 & 0.101 & 0.044 & 0.003 & 0.149 \\
542 & 0.284 & 0.167 & 0.000 & 0.498 \\
627 & 0.457 & 0.322 & 0.000 & 0.803 \\
538 & 0.103 & 0.054 & 0.000 & 0.153 \\
1468 & 0.118 & 0.097 & 0.000 & 0.233
\end{tabular}


Table 3 Industry specific effects of Tariff and NTB

\section{Tariff}

\begin{tabular}{llrr} 
& \multicolumn{1}{c}{ SIC code } & Coefficient & Std. error \\
01 & AGRICULTURAL PRODUCTION CROPS & -1.499 & 2.78 \\
09 & FISHING, HUNTING, AND TRAPPING & -10.975 & 15.87 \\
10 & METAL MINING & 35.522 & $13.13 * * *$ \\
20 & FOOD AND KINDRED PRODUCTS & -0.668 & 1.53 \\
22 & TEXTILE MILL PRODUCTS & 9.348 & 7.83 \\
23 & APPAREL AND OTHER TEXTILE PRODUCTS & -1.068 & 1.54 \\
25 & FURNITURE AND FIXTURES & -0.698 & 2.53 \\
26 & PAPER AND ALLIED PRODUCTS & 5.394 & 2.27 \\
28 & CHEMICALS AND ALLIED PRODUCTS & -2.711 & 5.63 \\
29 & PETROLEUM AND COAL PRODUCTS & 23.21 & 16.72 \\
31 & LEATHER AND LEATHER PRODUCTS & 12.568 & 20.19 \\
32 & STONE, CLAY, AND GLASS PRODUCTS & 1.754 & 1.76 \\
33 & PRIMARY METAL INDUSTRIES & 1.231 & 1.91 \\
34 & FABRICATED METAL PRODUCTS & 1.265 & 1.6 \\
35 & INDUSTRIAL MACHINERY AND EQUIPMENT & 0.015 & 1.17 \\
36 & ELECTRONIC + OTHER ELECTRIC EQUIPMENT & -5.339 & $1.37 * * *$ \\
37 & TRANSPORTATION EQUIPMENT & 5.148 & 5.69 \\
38 & INSTRUMENTS AND RELATED PRODUCTS & -3.426 & $1.5 * *$
\end{tabular}




\section{NTB}

\begin{tabular}{|c|c|c|c|}
\hline & SIC code & Coefficient & Std. Error \\
\hline 01 & AGRICULTURAL PRODUCTION CROPS & 0.006 & 0.13 \\
\hline 02 & AGRICULTURAL PRODUCTION LIVESTOCK & -0.006 & 0.1 \\
\hline 08 & FORESTRY & -0.063 & 0.18 \\
\hline 09 & FISHING, HUNTING, AND TRAPPING & -0.57 & 0.4 \\
\hline 10 & METAL MINING & -34.772 & 12.31 \\
\hline 13 & OIL AND GAS EXTRACTION & -0.008 & 0.11 \\
\hline 14 & NONMETALLIC MINERALS, EXCEPT FUELS & 0.475 & 0.37 \\
\hline 20 & FOOD AND KINDRED PRODUCTS & 0.023 & 0.11 \\
\hline 22 & TEXTILE MILL PRODUCTS & 0.104 & 0.18 \\
\hline 23 & APPAREL AND OTHER TEXTILE PRODUCTS & 0.102 & 0.11 \\
\hline 24 & LUMBER AND WOOD PRODUCTS & 0.016 & 0.1 \\
\hline 25 & FURNITURE AND FIXTURES & 1.433 & 21.49 \\
\hline 26 & PAPER AND ALLIED PRODUCTS & -69.456 & 47.63 \\
\hline 27 & PRINTING AND PUBLISHING & 8.851 & 9.05 \\
\hline 28 & CHEMICALS AND ALLIED PRODUCTS & 0.177 & 0.11 \\
\hline 29 & PETROLEUM AND COAL PRODUCTS & 0.057 & 0.11 \\
\hline 30 & RUBBER AND MISC. PLASTICS PRODUCTS & 0.109 & 0.26 \\
\hline 31 & LEATHER AND LEATHER PRODUCTS & 0.211 & 0.27 \\
\hline 32 & STONE, CLAY, AND GLASS PRODUCTS & -0.041 & 0.56 \\
\hline 33 & PRIMARY METAL INDUSTRIES & 0.196 & 0.15 \\
\hline 34 & FABRICATED METAL PRODUCTS & 0.117 & 0.12 \\
\hline 35 & INDUSTRIAL MACHINERY AND EQUIPMENT & -0.109 & 0.16 \\
\hline 36 & ELECTRONIC + OTHER ELECTRIC EQUIPMENT & 0.096 & 0.11 \\
\hline 37 & TRANSPORTATION EQUIPMENT & 0.05 & 0.11 \\
\hline 38 & INSTRUMENTS AND RELATED PRODUCTS & 0.054 & 0.21 \\
\hline
\end{tabular}




\section{Chapter 5}

\section{Conclusion and the Direction of Future Research}

This dissertation tackles three selected issues pertaining to economic integration.

It first focuses on the intro-bloc trade negotiation process in the presence of illegal immigration. Trade policy and immigration policy tend to be dealt separately and its mutual relation is often overlooked by both academics and policy makers. It illuminates this interrelation hoping that policy makers take two issues together in building the appropriate trade and immigration policies. We find that trade liberalization increases the amount of illegal immigration. Further, the condition under which a complete free trade still improves welfare of an economy even in the presence of illegal immigration is identified. It also extends the analysis by adding endogenous terms of trade. The optimal trade policy becomes complex as it depends on how tariffs affect the wage rate of own and the partner country, how tariffs affect terms of trade, and how tariffs and terms of trade influence illegal immigration. Understanding these relations is a key for a successful trade negotiation.

The second issue tackled in the dissertation is how international trade and factor flows impact domestic taxation. We looked the effective tax rates on earnings from the capital and labor incomes and from the consumption expenditure to answer the question. There has been a strong concern particularly in Europe that the wave of economic integration has forced the countries to shift the tax burden from capital to labor. As European countries have had higher unemployment rates and some argue that it is due to a high labor tax rate, whether economic integration has some impacts on domestic 
taxation is a critical question that should be answered. The question is also relevant to many developing countries where the capital market is still premature stage of development while earnings from the labor market remain low. Meanwhile, they receive more and more pressure to open their economy through bilateral and multilateral trade negotiations. Our empirical study shows that trade and capital flow have not affected the average effective tax rates on capital or labor. However, increase in trade and factor flows are associated with lower consumption tax rate. Labor inflow is associated with a lower capital tax rate. We could not confirm the claim that the tax burden has been shifted from capital to labor due to economic integration.

Finally, the dissertation raised the question whether domestic labor is mobile enough that trade policy has an identical impact on the wage rate throughout regions in a country. We chose the United States as a case study as we take advantage of a large number of regional wage data and the extensively available tariff and Non-Tariff Barriers data. We find some evidence that changes in tariff and Non-Tariff Barriers have had regional impacts in the United States. Skill premium changed in opposite directions among different regions. The change in trade policy raised the wage rate in one region but lowered in another region even if two are the same skill workers. The study reveals that the assessment of the trade policy requires both its impact on a national welfare and redistribution of regional welfare.

Future research will focus on four issues that are not answered in the dissertation. First, how much a tariff reduction actually increases immigration is an empirical question that has to be examined. The actual figure of illegal immigration is almost impossible to comprehend, but the number of undocumented aliens apprehended can suggest the 
qualitative implication. Furthermore, the data on legal immigration has been improved and obtainable even at different skill levels. These may help us understand better how the overall trend toward free trade has influenced labor flows around the world. Second, no country has taken a drastic path of trade liberalization from a closed economy to a complete open economy. The path of trade liberalization has been gradual for all countries. When considering the effect on factor flows, then, what would be the optimal dynamic speed of trade liberalization? This is the second agenda for future research. Third, does economic integration lead to change in tax incident among different income group? Our study finds that it leads to lower consumption tax which is the most repressive taxation. Do low income groups benefit from economic integration because of this change? Finally, did the abundant factor in each region lose from changes in tariff and NTB? Previous literature confirms that different regions in the United States have different factor abundance and our study finds that there are winners and losers among the regions for each skill category of workers. Whether those who lose from change in trade policy are the owners of abundant factor in each region is the empirical question that remains for future research. 


\section{References}

Arellano, M., and S. Bond, 1991, "Some Tests of Specification for Panel Data: Monte Carlo Evidence and an Application to Employment Equations", Review of Economic Studies, vol.58, no. 2, pp277-297

Anderson, M. A., R. Robertson, and S. L. S. Smith, 2001, "Measuring skill intensity: Production worker vs. education data in the NAFTA countries," Office of Economics Working Paper, U.S. International Trade Commission

Baltagi, B. H., 2001, Econometric Analysis of Panel Data, John Wiley \& Sons, West Sussex, England

Baltagi, B. H., and Q. Li, 1991, "A transformation that will circumvent the problem of autocorrelation in an error component model", Journal of Econometrics 48, pp393-385

Baltagi, B. H., and P. X. Wu, 1999, "Unequally spaced panel data rgression with AR(1) disturbances", Econometric theory 15, pp814-823

Bhargava, A., L. Franzini and W. Narendranathan, 1982, "serial correlation and fixed effects model”, Review of Economic Studies 49, pp533-549

Baldwin, R.E. and A. J. Venables, 1995, Regional economic integration, In: Grossman, G., Rogoff, K. (Ed.), Handbook of International Economics, Vol. 3 Noth-Holland, Amsterdam.

Bandyopadhyay, S., 2003, "Illegal immigration and Second Best Import Tariffs", Review of International Economics, forthcoming.

Bernard, A. B., J. B. Jensen, and P. K. Schott, 2001, "Factor Price Equality and the Economies of the United States," NBER Working Paper Series, Working Paper No. 8068

Bernard, A. B., R. Robertson, and P. K. Schott, 2004, "Is Mexico a lumpy country?," NBER Working Paper Series, Working Paper No. 10898

Bernard, A. B., S. Redding, P. K. Schott, and H. Simpson, 2002, "Factor Price Equalization in the UK?," NBER Working Paper Series, Working Paper No. 9052

Bond, E. W. and T. J. Chen, 1987, "The welfare effects of illegal immigration," Journal of International Economics, vol. 23, pp315-328.

Bond, E. W., R. G. Riezman, and C. Syropoulos, 2004, "A strategic and welfare theoretic analysis of free trade areas”, Journal of International Economics, Vol. 64, pp1-27. 
Bond, E. W., C. Syropoulos, and L. A. Winters, 2001, "Deepening of regional integration and multilateral trade agreements", Journal of International Economics, vol. 53, pp335-361.

Carey, D. and J. Rabesona, 2002, "Tax Ratios on Labour and Capital Income and on Consumption," OECD Economic Studies, No. 35

Courant, P. N. and A. V. Deardorff, 1992, “international Trade with Lumpy Countries," Journal of Political Economy, vol. 100, no.1, pp198-210

Cox, C. P., 1987, A Handbook of Introductory Statistical Methods, John Wiley \& Sons, Inc., the United States of America

Dumond, J. M., B. T. Hirsch, and D. A. MacPherson, 1999, "Wage Differentials across Labor Markets and Workers: Does Cost of Living Matter?," Economic Inquiry, Vol. 37, No. 4, pp577-598

Debaere, Peter, 2004, "Does lumpiness matter in an open economy? Studying international economics with regional data," Journal of International Economics, 64 , no. 2, pp485-501

Ethier, W. and H. Horn, 1984, “A new look at economic integration”, In: Kierzkowski, H., ed., Monopolistic Competition and International Trade, Oxford University Press, Oxford.

Ethier, W. J., 1986, "Illegal Immigration: The Host-Country Problem,” American Economic Review, vol. 76, no. 1, pp56-71.

European Commission, 1997, Towards tax co-ordination in the European Union: A package to tackle harmful tax competition. COM(97) 495 final.

Feenstra, R. C., J. Romalis and P. K. Schott, 2002, “U.S. Imports, Exports and Tariff Data, 1989-2001”, NBER Working Paper 9387

Hall, R. E. and D. W. Jorgenson, 1967, "Tax Policy and Investment Behavior," American Economic Review, vol. 57, no. 3, pp. 391-414

Hamermesh, D. S., 1993, Labor Demand, Princeton University Press, Princeton.

Jorgenson, D. W., 1963, "Capital Theory and Investment Behavior," American Economic Review, vol. 53, no 3, pp247-259)

Jorgenson, D. W. and J. A. Stephenson, 1969, "Issues in the Development of the Neoclassical Theory of Investment Behavior," Review of Economics and Statistics, vol. 51, no. 3, pp. 346-353 
King, M. A. and D. Fullerton, 1984, The Taxation of Income from Capital: A Comparative Study of the United States, the United Kingdom, Sweden, and West Germany. Chicago: University of Chicago Press.

Kiviet, J. F., 1995, "On bias, inconsistency and efficiency of various estimators in dynamic panel data models," Journal of Econometrics 68, pp53-78

Lillard, L. A., and R. J. Willis, 1978, "Dynamic aspects of earning mobility”, Econometrica 46, pp985-1012

Melvin, J. R., 1985, “The Regional Economic Consequences of Tariffs and Domestic Transportation Costs," Canadian Journal of Economics, vol. 18, no. 2, pp237-257

Mendoza, E. G., A. Razin and L. L. Tesar, 1994, "Effective tax rates in macroeconomics Cross-country estimates of tax rates on factor incomes and consumption", Journal of Monetary Economics 34, pp 297-323

Nickell, S., 1981, "Biases in dynamic models with fixed effects", Econometrica 49, pp1417-1426

O'Connell, P. G.J., and S.Wei, 2002, "The Bigger they are, the harder they fall: Retail price differences across U.S. cities," Journal of International Economics 56, pp21-53

Orrenius, P., 2001, "Illegal Immigration and Enforcement Along the U.S.-Mexico Border: An Overview", Economic \& Financial Review, $1^{\text {st }}$ quarter, Federal Reserve Bank of Dallas.

Panagariya, A., 1999, “The Meade Model of Preferential Trading: History, Analytics, and Policy Implications," in Trading Blocs: Alternative Approaches to Analyzing Preferential Trade Agreements, ed. Bhagwati, J., P. Krishna and A. Panagariya, MIT Press.

Panagariya, A. and P. Krishna, 2002, "On necessarily welfare-enhancing free trade areas", Journal of International Economics, Vol. 57, pp353-367.

Razin, A., E. Sadka and P. Swagel, 2002, "Tax burden and migration: a political economy theory and evidence", Journal of Public Economics 85, pp 167-190

Rodrik, D., 1997, HAS GLOBALIZATION GONE TOO FAR?, Institute for International Economics, Washington, DC

Slaughter, M. J., 2001, "International trade and labor-demand elasticities", Journal of International Economics 54, pp27-56 
Sorenen, P. B., 2004, Measuring the Tax Burden on Capital and Labor, Cambridge, The MIT Press

United States General Accounting Office, 2001, Report to Congressional Committees, "INS's Southwest Border Strategy: Resource and Impact Issues remain After Seven Years", August

U.S. Immigration and Naturalization Service, 2001, 2001 Statistical Yearbook of the Immigration and Naturalization Service. 